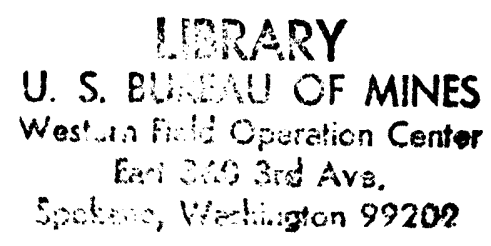

UKEAU Ut MINE.

\title{
Surficial Geology and Geomorphology of the Mountain Lake Area, Giles County, Virginia, Including Sedimentological Studies of Colluvium and Boulder Streams
}

U.S. GEOLOGICAL SURVEY PROFESSIONAL PAPER 1469 


\section{Surficial Geology and Geomorphology of the Mountain Lake Area, Giles County, Virginia, Including Sedimentological Studies of Colluvium and Boulder Streams}

\section{By HUGH H. MILLS}

\begin{tabular}{llllll}
\hline U. S. GEOLOGICAL & SURVEY & PROFESSIONAL & PAPER & 1469
\end{tabular}

The distribution and sedimentary properties of surficial deposits in a small upland area of the central Central Appalachians and the geomorphic implications

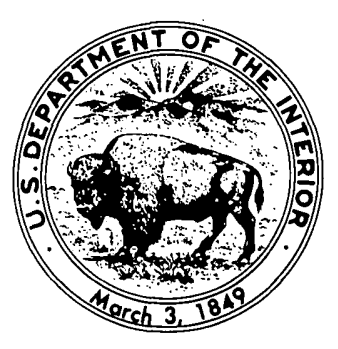




\title{
DEPARTMENT OF THE INTERIOR \\ DONALD PAUL HODEL, Secretary
}

\section{U.S. GEOLOGICAL SURVEY}

\author{
Dallas L. Peck, Director
}

\begin{abstract}
Any use of trade, product, industry, or firm names in this publication is for descriptive purposes only and does not imply endorsement by the

U.S. Government.
\end{abstract}

\section{Library of Congress Cataloging in Publication Data}

Mills, Hugh $\mathrm{H}$.

Surficial geology and geomorphology of the Mountain Lake area, Giles County, Virginia, including sedimentological studies of colluvium and boulder streams.

(Geological Survey professional paper ; 1469)

"The distribution and sedimentary properties of surficial deposits in a small upland area of the central Appalachians, and the geomorphic implications."

Bibliography: $p$.

Supt. of Docs. no.: I 19.16: 1469

1. Geology-Virginia-Mountain Lake Region. 2. Sedimentation and deposition-Virginia-Mountain Lake Region. 3. Geomorphology-Virginia-Mountain Lake Region. I. Title. II. Series.
QE174.M68M55
1987
$557.55^{\prime} 782$
$87-600042$

For sale by the Books and Open-File Reports Section, U.S. Geological Survey, Federal Center, Box 25425, Denver, CO 80225 


\section{CONTENTS}

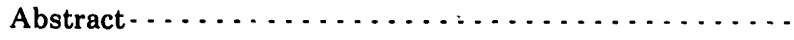
Introduction..$\ldots \ldots \ldots \ldots \ldots \ldots \ldots \ldots \ldots \ldots \ldots \ldots$

Setting of the study area.$\ldots \ldots \ldots \ldots \ldots \ldots \ldots$. Bedrock geology and topography..........

Present and past climate..............

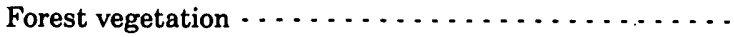

General surficial geology and geomorphology . . . . . . . .

Previous mapping of surficial geology in the

unglaciated Appalachians . . . . . . . . . .

Surficial deposits and their distribution . . . . . . . . .

Distribution of surficial deposits in four areas . . . . . . .

Doe Creek drainage basin . . . . . . . . . . . . .

Little Stony Creek basin below the Cascades . . . . . .

Little Stony Creek basin above the Cascades . . . . . .

North slope of Big Mountain - . . . . . . . . . . . .

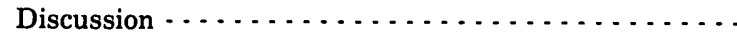

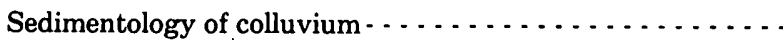

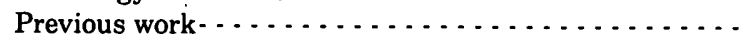

Differentiation of colluvial environment and age by sedimentologic and weathering criteria $\ldots . .$.

Particle-size analysis. . . . . . . . . . . . . . . .

Clast roundness $\ldots \ldots \ldots \ldots \ldots \ldots \ldots . . . . . . .$.

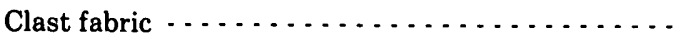

Weathering indices...$\ldots \ldots \ldots \ldots \ldots$
1 2

2

2

5

5

6

6

7

10

10

15

16

19

19

24

24

25

26

27

29

32
Sedimentology of colluvium-Continued

Differentiation of colluvial environment and age by sedimentologic and weathering criteria-Continued

Weathering rinds of Tuscarora Quartzite clasts ....

Vertical variation in weathering characteristics ....

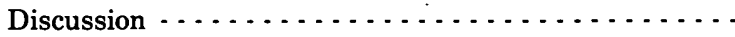

Hillslope evolution model and colluvium . . . . . . .

Ages of the deposits $. . \ldots \ldots \ldots \ldots \ldots . . . . .$.

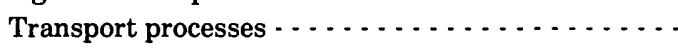

Geomorphology and sedimentology of boulder streams . . . .

A genetic classification of boulder streams. . . . . . .

Procedure and sedimentologic considerations . . . . . . . .

Possible type I deposits: Products of gravity processes $\ldots . . . . . . . . . .$.

Possible type II deposits: Products of periglacial processes $\ldots . . . . . . . . . .$.

Possible frost-heave deposits $. . . \ldots \ldots \ldots . .$.

Possible gelifluction deposits.........

Possible type III deposits: Products of debris flows - . . .

Observations on relative ages of the deposits ........

Discussion . . . . . . . . . . . . . . . . . .

Surficial deposits and seismicity $\ldots \ldots \ldots \ldots \ldots$.

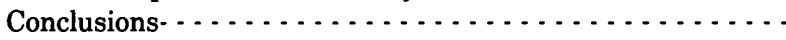

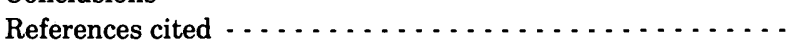
34

\section{ILLUSTRATIONS}

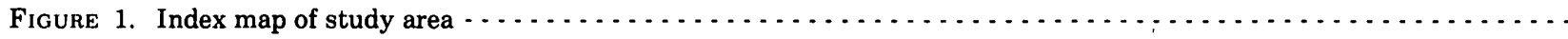

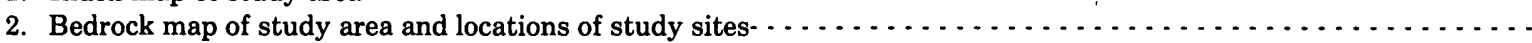

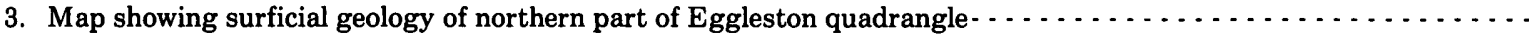

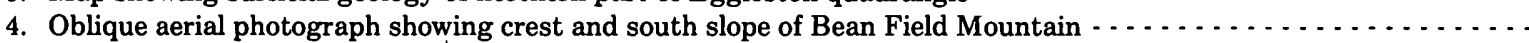

5. Oblique aerial photograph of upper end of Doe Creek drainage basin, showing location of various types of regolith - -

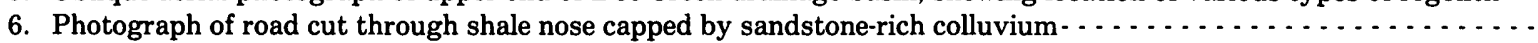

7. Photograph of south slope of Doe Mountain, showing large V-shaped hollows . . . . . . . . . . . . . . . . .

8. Diagram showing boulder abundance as it relates to the location of Tuscarora Quartzite outcrops .............

9-12. Photographs of:

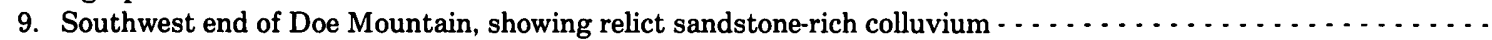

10. Boulder stream on northwest flank of Doe Mountain . . . . . . . . . . . . . . . . . . . . . .

11. South flank of Butt Mountain as viewed from crest of Doe Mountain . . . . . . . . . . . . . . . . . . .

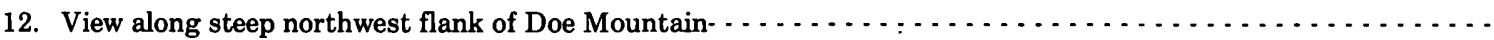

13. Map showing surficial geology of southern part of Interior quadrangle . . . . . . . . . . . . . . . . . .

14. Low oblique aerial photograph showing flatiron on south (dip) slope of Big Mountain . . . . . . . . . . . . . .

15-17. Photographs of:

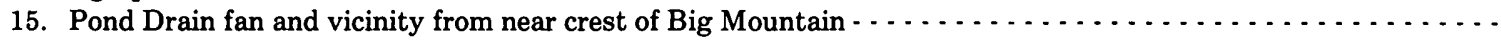

16. Road cut through matrix-free boulder stream on north side of Big Mountain . . . . . . . . . . . . . . . .

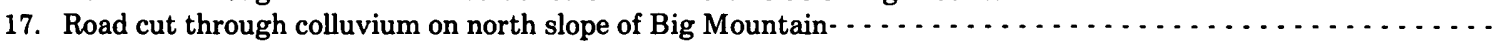

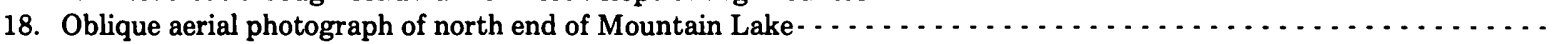

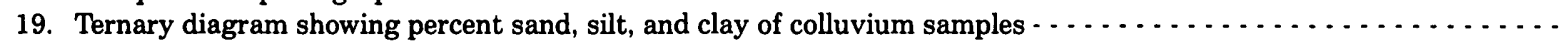

20. Graph showing average cumulative particle-size curves for each colluvial environment - . . . . . . . . . . . . .

21. Ternary diagram showing percent gravel, sand, and silt +clay in each colluvial environment - . . . . . . . . . . .

22. Graph showing mean pebble roundness as a function of distance from mountain crest ................... . .

23. Composite contoured equal-area stereographic nets for each colluvial environment $-\ldots . . . . . . . . . . . .$. 
24. Equal-area stereographic net showing the azimuth and dip of $V_{1}$ (the axis of maximum concentration) for

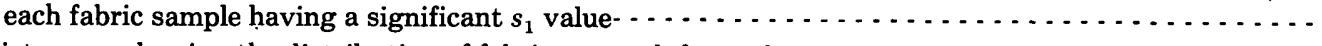

25. Histogram showing the distribution of fabric strength for each environment, as indicated by the $s_{1}$ value,

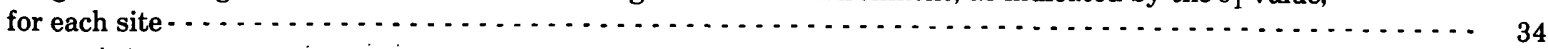

26. Schematic diagram of colors and combinations of weathering rinds observed on sandstone clasts $\ldots \ldots \ldots \ldots$

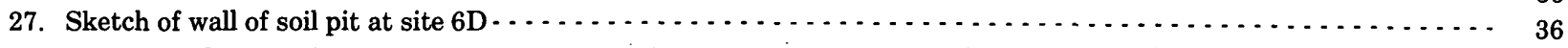

28. Diagrams showing the most commonly observed fabric patterns of slope deposits, plotted as contoured,

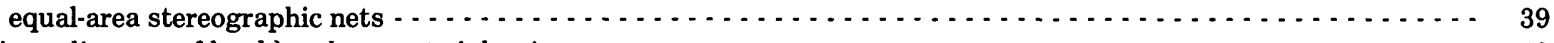

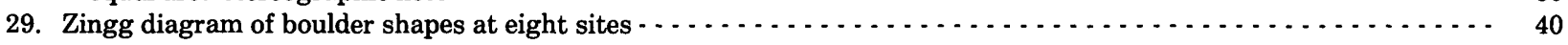

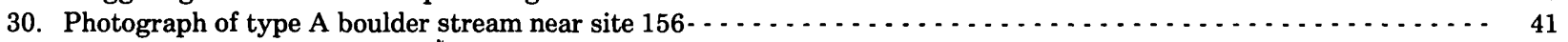

31. Surface-boulder fabrics at sites 156 and 137 (type A boulder streams), presented as contoured, equal-area

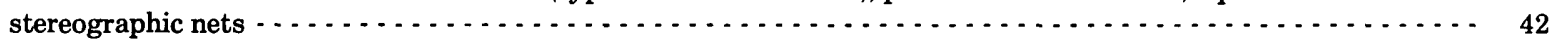

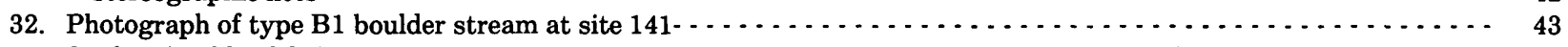

33. Surface-boulder fabrics at sites $100,141,142$, and 154 (type B1 boulder streams), presented as contoured, equal-area

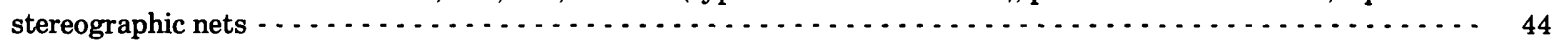

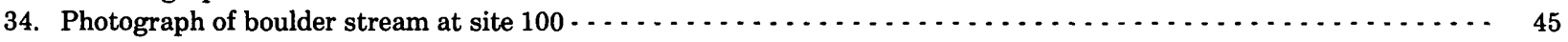

35. Longitudinal topographic profile of boulder stream at site 100 , showing boulder size at $3-\mathrm{m}$ intervals.$\ldots \ldots \ldots$

36. Transverse topographic profile of boulder stream at site 100 , showing boulder size at $0.5-\mathrm{m}$ intervals $\ldots \ldots \ldots \ldots . . .47$

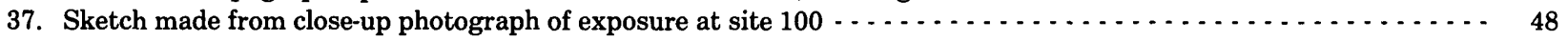

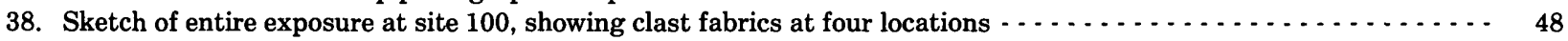

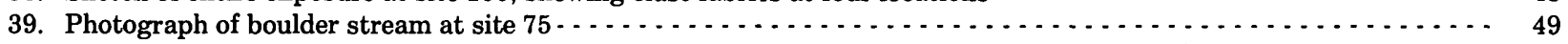

40. Photograph of boulder stream having convex-up transverse topographic profile (site 140) $\ldots \ldots \ldots \ldots \ldots \ldots$

41. Surface-boulder fabrics at sites $75,140,151$, and 153 presented as contoured equal-area stereographic nets $\cdots \ldots . . .51$

\section{TABLES}

TABLE 1. Bedrock stratigraphic units in the study area- Page

2. Sedimentary characteristics, or values, of colluvium from five environments defined in the study area $\ldots \ldots \ldots \ldots$

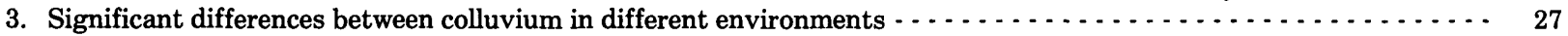

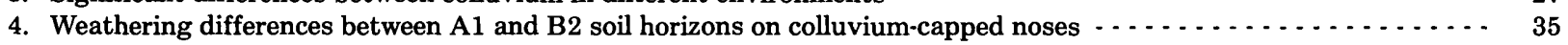

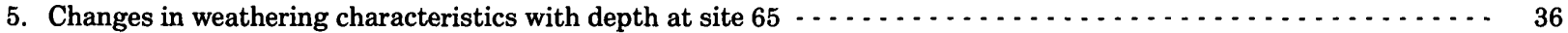

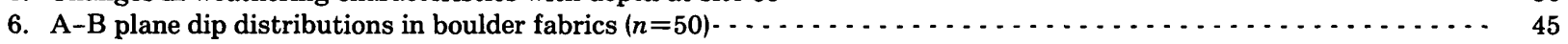

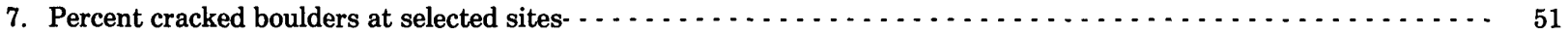

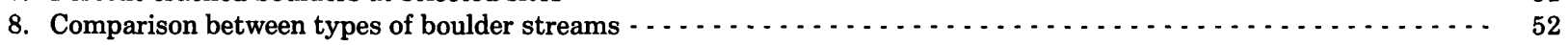




\title{
SURFICIAL GEOLOGY AND GEOMORPHOLOGY OF THE MOUNTAIN LAKE AREA, GILES COUNTY, VIRGINIA, INCLUDING SEDIMENTOLOGICAL STUDIES OF COLLUVIUM AND BOULDER STREAMS
}

\author{
By Hugh H. Mills ${ }^{1}$
}

ABSTRACT

Extensive areas of shale and limestone bedrock in a small upland area in the Valley and Ridge province are overlain by sandstone-rich colluvium derived from mountain caprocks. Sandstone boulders tend to be concentrated in hollows rather than on noses and are more numerous in moister than in drier hollows. Some of the colluvium is very old, as indicated by its presence on hilltops or in piedmont areas where presently there are no sandstone outcrops upslope. The distribution of this relict material indicates how the landscape has evolved through time, particularly in regard to the retreat of sandstone escarpments. The gross features of the topography are controlled by the general structure and lithology of the bedrock. Detailed mapping of surficial deposits, however, shows more subtle influences of bedrock characteristics on topography. For example, resistant boulders derived from sandstone outcrops affect the form of shale slopes that they overlie, both by influencing the form of hollows incised into the slopes and by determining the amount of retreat that the slopes undergo due to lateral erosion by streams at their bases.

The study of colluvium on mountain flanks in this area shows that five environments of colluvium deposition can be differentiated on the basis of texture, color, clast weathering, pebble roundness, and clast fabric: upper, steeply sloping noses nearer the mountain crest; lower, gently sloping noses farther from the crest; moist hollows near the mountain crest; dry hollows or those farther from the crest; and side slopes or other steep slopes. Sediments in the two nose environments are distinguished from those in other environments by more intense weathering (as indicated by finer texture, redder hue, and a greater percentage of weathered clasts), with weathering in the lowernose setting being especially intense. Sediments in the two hollow environments are distinguished from each other by clast fabric, with sediments in moist hollows near the mountain crest showing much more consistent downslope orientation of clast long axes.

The differences in degree of weathering appear to result in large part from differences in age, the colluvium on lower noses being oldest, that on upper noses being younger, and that in hollows and on side slopes being youngest. Age differences probably reflect the manner in which mountain-slope topography evolves. The most rapid downslope movement of colluvium occurs in hollows; colluvial caps on noses commonly are former hollow fills that reached their present positions by topographic reversal. Once on noses, the relict coliuvium ceases to move until eventually eroded by a laterally migrating hollow, and therefore at any given time it usually is older and more weathered than the colluvium in hollows.

\footnotetext{
${ }^{1}$ Tennessee Technological University, Department of Earth Sciences, Cookeville, TN 38505.
}

Differences in clast roundness and fabric appear to be related more closely to differences in transport distance and process than to differences in weathering. Clast roundness reflects mainly the distance of transport. Consistency of particle orientation probably indicates whether deposition was by laminar or turbulent flow. Colluvium with highly consistent particle orientation (indicative of laminar flow) may be a relict gelifluction deposit, whereas that lacking such orientation (indicative of turbulent flow) may be a debrisflow deposit produced by a catastrophic flood. Estimates of the ages of colluvial deposits based on the degree of weathering suggest that the hollow and side-slope colluvium is no older than late Wisconsinan, whereas at least some of the lower-nose colluvium probably is preIllinoian.

Concentrations of sandstone boulders in hollows, here referred to as boulder streams, extend as much as $1 \mathrm{~km}$ downslope from outcrops that produce them. On the basis of fabric and other properties, boulder streams were divided into four types. The first type occurs on slopes having gradients of about $35^{\circ}$, and boulders here are easily disturbed by stepping on them. Tabular boulders tend to be inclined downslope at an angle less than the slope of the surface on which they rest. Boulders are probably transported by sliding and rolling, and their instability and angularity suggest that these deposits are quite young. The second type of boulder stream rests on slopes that have gradients ranging from $8^{\circ}$ to $30^{\circ}$, are stable underfoot, and have irregular surfaces containing pits probably formed by eluviation of fines. Fabric analysis shows an exceptionally large number of tabular boulders with near-vertical orientations. As frost heave is the only process known to orient large clasts in this manner, it is inferred that such streams are relicts of Pleistocene periglacial regimes. Some support for a Pleistocene age is provided by the fact that these deposits generally appear to be more weathered and stable than other boulder deposits and also tend to be located away from modern drainageways. The third and fourth types have a gradient range similar to that of the second type but have a matrix of fines, a relatively smooth surface, and tabular boulders that tend to dip downhill at an angle less than that of the slope angle. The properties of these boulder streams are consistent with an origin both by gelifluction and by debris flow. It is hypothesized that the third type of boulder stream, which is underlain by colluvium having consistently oriented clasts and which occurs near mountain crests, is relict gelifluction deposits of Pleistocene age, whereas the fourth type, which shows poorly developed fabrics and which is located far from the crests, is debris-flow deposits of Holocene age.

No evidence of faulting or liquefaction that might be indicative of Quaternary seismicity was found in the regolith. 


\section{INTRODUCTION}

Compared with many other regions, the central and southern Appalachian region has quite restricted late Cenozoic deposits. Most surficial deposits in this area have never been mapped because of their small size and limited economic potential. The terrace deposits of a few larger rivers have been studied by Quaternary geologists because the lower terraces may be correlated and often yield datable organic material. Colluvium, however, although the most widespread deposit in the region, has received almost no attention. Geologists generally have assumed that the distribution and characteristics of colluvium can be deduced from knowledge of the underlying bedrock and that this material has little significance except for soil scientists. This study of a small area in the vicinity of Mountain Lake, Virginia, attempts to show that detailed mapping of colluvium and other upland surficial deposits can make a significant contribution to the understanding of landscape development.

The sedimentary characteristics of colluvium and boulder streams are also examined in this paper. Colluvium has been investigated in some detail in periglacial environments. Because corresponding studies on colluvium from nonperiglacial environments have been few, however, exactly which sedimentary properties can be used to identify periglacial slope deposits remain unknown, despite the importance of this question for a more complete understanding of Quaternary geology. Another important characteristic of colluvial deposits is age. Although age measurements are rare for colluv. ium, relative ages, determined by a study of the weathering features of deposits, can readily be obtained and are useful for the study of hillslope evolution. In this study, two aspects of colluvium were examined: (1) the variation in degree of weathering and other sedimentary properties among different topographic settings and (2) sedimentary evidence for transport and deposition by catastrophic floods and periglacial processes.

Bouldery scree is common in the study area, particularly in hollows that head below sandstone outcrops. ("Scree" herein means unconsolidated rock fragments on a mountain slope. "Talus" is a landform composed of scree, particularly at the base of a ledge or cliff.) Concentrations of boulders in hollows are referred to herein as "boulder streams." Many investigators have suggested that widespread scree deposits are evidence for periglacial activity in the southern and central Appalachians during glacial stages of the Pleistocene (for example, King, 1964; Fiedler, 1967; Michalek, 1968; Haselton, 1973; Godfrey, 1975; Hedges, 1975). Hack $(1960,1965)$, however, provided evidence that at least some scree is being produced during present climatic conditions, and he suggested that scree develops wher- ever slopes are steep and the bedrock is mechanically strong and resistant to chemical weathering, regardless of climate.

Boulder streams might be relics of transport by periglacial frost action or gelifluction but probably also can be deposited by catastrophic floods that occur during rare, extremely intense rainfalls. The approach used to interpret these features was to compare the characteristics of boulder streams in the Mountain Lake area with those reported for boulder deposits of known origin elsewhere.

In the discussion below, "periglacial" is used in a sense similar to that of Washburn $(1980$, p. 4) to designate processes and features of cold climates characterized by intense frost action. The assumption is made that in southwest Virginia such conditions could not have existed after the Pleistocene glacial climates, which ended there about 13,000 to 15,000 yr B.P. (Watts, 1979). "Gelifluction" is used in the sense of Baulig (1957) as solifluction associated with frozen ground, including seasonally frozen ground as well as permafrost.

\section{SETTING OF THE STUDY AREA}

\section{BEDROCK GEOLOGY AND TOPOGRAPHY}

The study area is in the vicinity of Mountain Lake in Giles County, in the Valley and Ridge province of southwestern Virginia (fig. 1). A stratigraphic column for the study area is shown in table 1 , and a simplified geologic map is presented in figure 2 .

Structurally, most of the study area is characterized by broad, open folds. The southernmost fold, the Johns Creek syncline, trends N. $60^{\circ} \mathrm{E}$. and plunges gently northeast; dips are somewhat steeper in the southeast limb. Northwest of this fold is the Mountain Lake anticline, having a similar trend and plunge, and the more complex Butt Mountain synclinorium (Eckroade, 1962). This structure trends N. $65^{\circ} \mathrm{E}$. and near the crest of Butt Mountain plunges $10^{\circ}$ to $20^{\circ}$ to the northeast. In the study area, this structure is composed of one major depression and several minor folds. The synclinorium is asymmetrical along the upper reach of Little Stony Creek, with the northwest limb dipping $35^{\circ}$ and the same units on the southeast limb dipping $15^{\circ}$. Two high-angle faults repeat parts of the Juniata, Tuscarora, Rose Hill, and "Keefer" Formations (fig. 2). On the north flank of Big Mountain is a northwestwardoverturned anticline, with the southeast limb dipping about $20^{\circ}$ and the northwest limb about $45^{\circ}$. Because of this fold and the high-angle fault, both the Tuscarora Quartzite and "Keefer" Sandstone are repeated three 


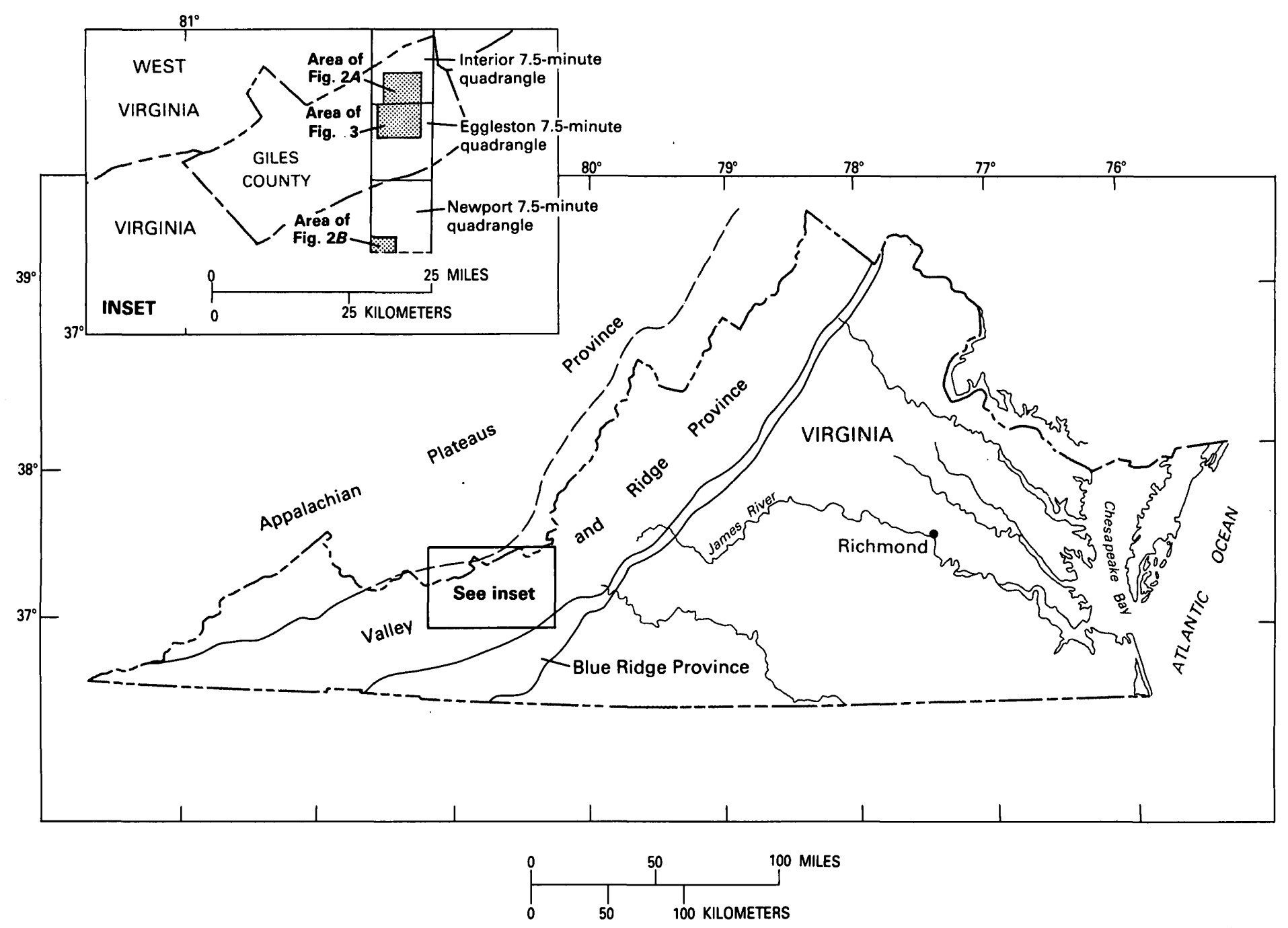

FIGURE 1.-Index map of study area. Study area is shaded. Also shown are those parts of the study area that were mapped.

times on the north slope of Big Mountain. Near the base of this slope is a minor syncline.

The study area lies immediately northeast of the New River, which constitutes the local base level. Salt Pond Mountain, the highest peak in the area (elev. 1,326 m), is $836 \mathrm{~m}$ higher than the New River. The major mountains in the area (fig. 2) are strike ridges. Numerous first-order valleys corrugate the flanks of these ridges. Hack and Goodlett (1960) divided such corrugated ridge-flank topography into hollows, noses, and side slopes. Hollows are the central parts of first-order valleys, where the contours are concave downhill. Noses are the divides between hollows, where the contours are convex downhill. Side slopes are the areas between noses and hollows characterized by straight contours. On the higher mountain slopes the alternation between hollows and noses is fairly regular but is somewhat less regular on the lower slopes (fig. 2).

The three largest streams in the map area are Stony Creek, Little Stony Creek, and Doe Creek (fig. 2). Only a short reach of Stony Creek lies in the study area, so this stream will not be discussed. The remaining two streams flow at elevations more than $600 \mathrm{~m}$ below the elevations of the ridge crests. The valley of Little Stony Creek is much narrower and steeper walled than that of Doe Creek. The reason for this difference seems to be the very steep gradient of Little Stony Creek downstream from the waterfalls known as the Cascades (fig. 2), which are formed by two prominent cliffs, an upstream one in the "Keefer" Sandstone and a downstream one in the Rose Hill Formation. Gradients this steep are confined to the upper 2 or $3 \mathrm{~km}$ of Doe Creek 


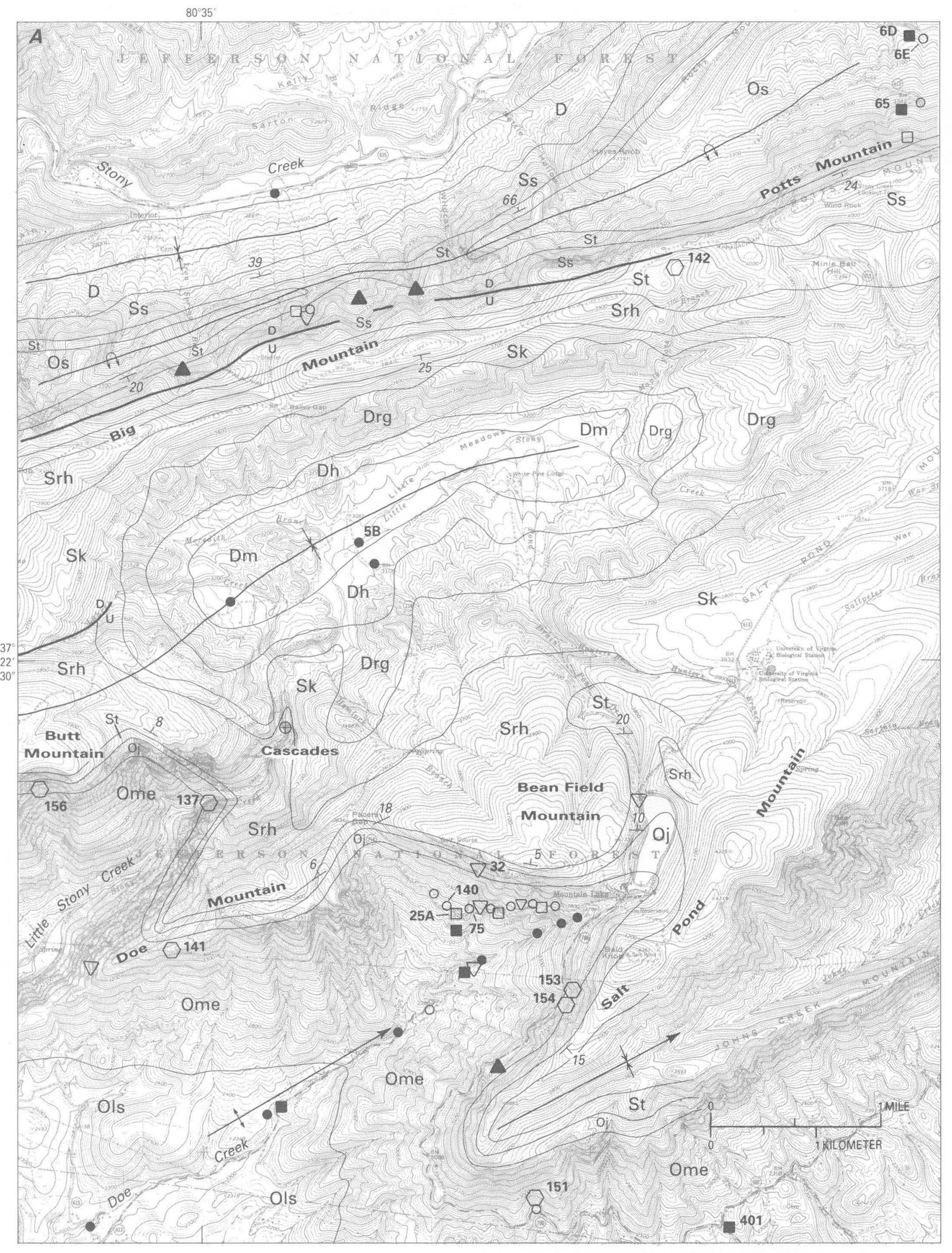




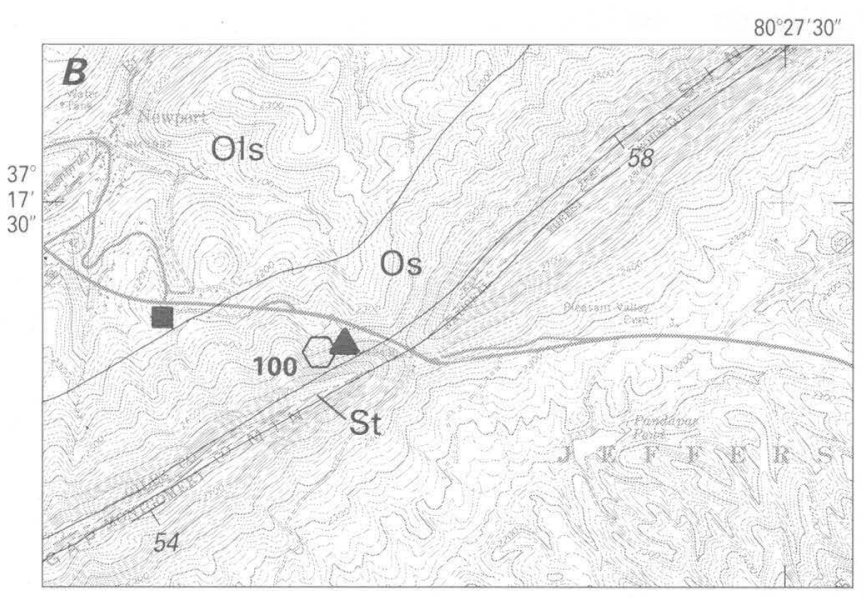

\section{EXPLANATION}

Dm Millboro Shale (Devonian)

Dh Huntersville Chert (Devonian)

Drg Rocky Gap Sandstone of Swartz (1929) (Devonian)

D Devonian units, undivided-Includes Millboro Shale, Huntersville Chert, and Rocky Gap Sandstone

Sk "Keefer" Sandstone (Silurian)

Srh Rose Hill Formation (Silurian)

St Tuscarora Quartzite (Silurian)

Ss Silurian sandstones other than Tuscarora QuartziteIncludes "Keefer" Sandstone and Rose Hill Formation

Oj Juniata Formation (Ordovician)

Ome Martinsburg, Eggleston, and Moccasin Formations (Ordovician)

Ols Ordovician limestones, undivided (Middle Ordovician)

Os Ordovician sandstones, siltstones, and shales-Includes Juniata, Martinsburg, Eggleston, and Moccasin Formations

\section{EXPLANATION OF MAP SYMBOLS}

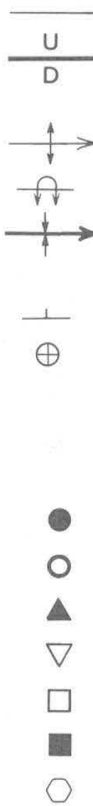

\section{Contact-Approximately located}

High-angle fault-Concealed. $\mathrm{U}$, upthrown side; D, downthrown side

Anticline-Showing direction of plunge where known

Overturned anticline-Showing direction of dip of limbs

Syncline-Showing direction of plunge where known

Strike and dip of bedding

Inclined

Horizontal

\section{TYPES OF SAMPLE LOCATIONS}

Alluvium

Type D hollows

Type $\mathrm{M}$ hollows

Side slopes

Upper noses

Lower noses

Boulder streams
Figure 2.-Simplified bedrock map of study area, modified from Eckroade (1962). On the north flank of Big Mountain, contacts are so closely spaced that formations have been combined. Locations of study sites are shown; only those sites referred to individually in the text are numbered. Often, multiple samples were collected at one site. Sites in the Newport quadrangle, which is outside the study area, are shown on the inset map. A few sites in the Eggleston and Interior quadrangles were outside the map area shown here.

and other streams in the region, but Little Stony Creek is already $10 \mathrm{~km}$ long where it reaches the Cascades. As Hack (1973) has stated, the power of a stream is approximately proportional to the product of the local gradient and the length of the stream, where length is measured from the drainage divide at the head of the stream to the center of the reach for which the gradient is computed. Thus, the power of Little Stony Creek in the reach below the Cascades is much greater than the power of Doe Creek in its headwaters reach, even though the gradients of the two reaches are similar. This relatively great power enables Little Stony Creek to transport much larger boulders than Doe Creek and also probably allows it to downcut more rapidly.

\section{PRESENT AND PAST CLIMATE}

Temperature and precipitation records have been maintained at the Mountain Lake Biology Station (elev. $1,180 \mathrm{~m}$ ) on the east side of the study area. From 1972 to 1979 , the mean annual temperature was $8.1^{\circ} \mathrm{C}$, and the mean annual precipitation was $1,436 \mathrm{~mm}$. The mean temperature for January was $-3.3{ }^{\circ} \mathrm{C}$, although sustained intervals of somewhat colder temperatures have occurred occasionally. For example, the mean temperature for January 1977 was $-10.4{ }^{\circ} \mathrm{C}$. The precipitation is fairly evenly distributed throughout the year, the driest month being February (mean precipitation 87.4 $\mathrm{mm}$ ) and the wettest, June (170.9 $\mathrm{mm})$.

Climate during the late Wisconsinan probably was much colder than at present. Watts (1979), on the basis of pollen and plant macrofossil studies, concluded that during this time sedge tundra covered the higher mountains of the central Appalachians. Clark (1968, and oral commun., 1979) excavated a large-scale stone stripe on Big Mountain in the present study area and found it to resemble closely features actively forming today only in permafrost regions. Hence, it is likely that the mean annual temperature here at the height of the last glaciation was $0^{\circ} \mathrm{C}$ or below.

\section{FOREST VEGETATION}

Hack and Goodlett (1960) noted that xeric (lowmoisture) tree types characterize noses, mesic 
TABLE 1.-Bedrock stratigraphic units in the study area

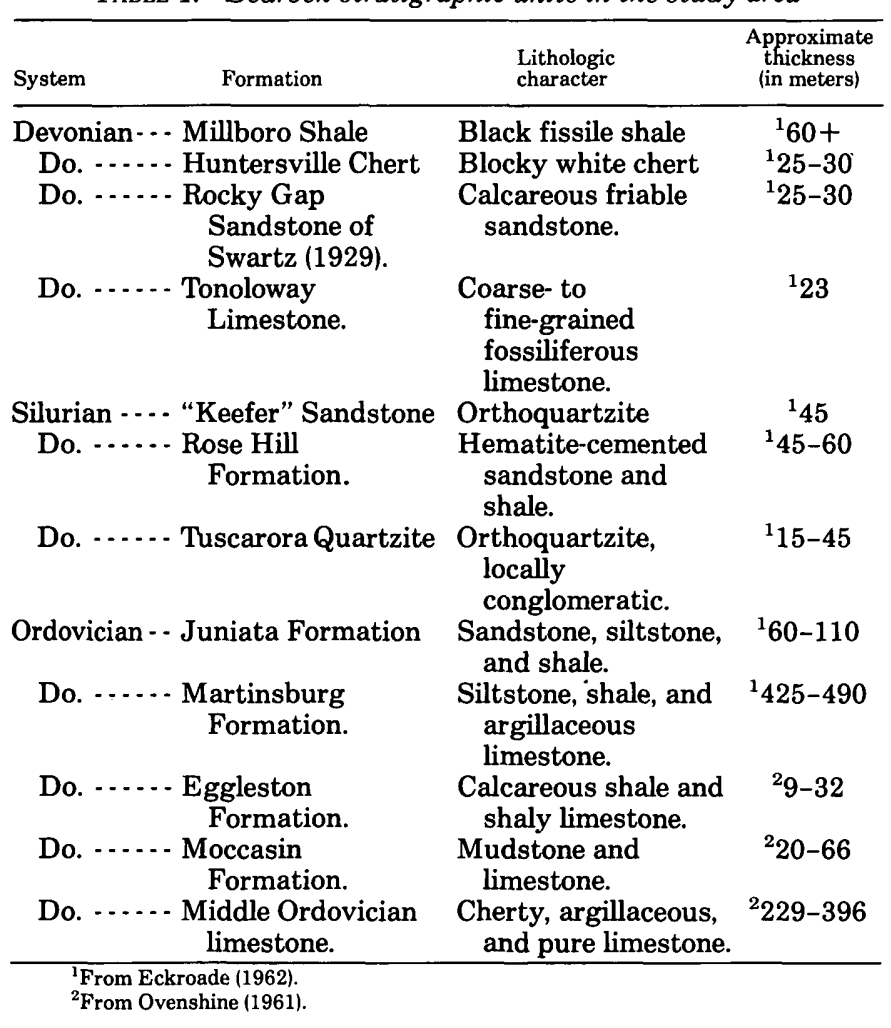

(moderate-moisture) types the hollows, and intermediate types the side slopes. Other factors, however, including the orientation of the hollows and side slopes, the size of the hollows, and the nature and attitude of the bedrock, also affect the forest type. Similar relationships were observed in the present setting. In moister, north-facing hollows, yellow birch (Betula alleghaniensis) and striped maple (Acer pensylvanicum) commonly are dominant, although in the wettest hollows, rosebay rhododendron (Rhododendron maximum) may dominate. In drier, south-facing hollows, basswood (Tilia) and sugar maple (Acer saccharum) are dominant, although in very dry hollows, oak (Quercus) and buckeye (Aesculus) may be as numerous or more numerous than basswood, and maples may be scarce. Bogs are characterized by eastern hemlock (Tsuga canadensis) and, at higher altitudes, red spruce (Picea rubens). Noses are characterized mainly by oaks (Quercus) and hickories (Carya). The most common pine in the area is eastern white pine (Pinus strobus), which occurs mainly in sandy areas.

\section{GENERAL SURFICIAL GEOLOGY AND GEOMORPHOLOGY}

The general nature and geographic distribution of the surficial deposits and the general geomorphology are considered in this section. Detailed descriptions of the deposits will be undertaken in later sections.

\section{PREVIOUS MAPPING OF SURFICIAL DEPOSITS IN THE UNGLACIATED APPALACHIANS}

Map unit differentiation of surficial rock units in settings such as that of the study area is difficult. Many types of deposits are too small in area to be shown on 1:24;000-scale maps. Consequently, only very generalized units can be used for mapping at this scale. In addition, grouping of deposits by age for the most part is somewhat arbitrary, as there are unlikely to be discrete age groups such as those that occur in glacial and stream-terrace deposits, and radiocarbon dates or other age measurements commonly are not available.

Pierce (1966) mapped four types of transported regolith in an area in Pennsylvania having bedrock similar to that in the present study area: (1) sandstone rubble with a plentiful matrix on moderate slopes; (2) gravelly alluvium and sandstone rubble on valley bottoms; (3) modern fine-grained alluvium; and (4) roundstone diamicton. The latter consists of older, weathered deposits characterized by rounded clasts in a reddishorange clayey matrix and lacking apparent sorting or stratification. Roundstone diamicton occurs on the lower slopes of mountains and on some outlying hills in Pierce's study area. Pierce considered the roundstone diamicton to be highly weathered alluvium. He also mapped residual regolith. However, although the manner in which residuum develops is an important problem, the spatial distribution of this material can be determined largely from bedrock maps. In contrast, the distribution of transported regolith can be predicted only partly from such maps. Because the distribution of transported regolith also can serve as a clue to the transporting mechanisms and, in addition, may reveal the manner in which the landscape is changing through time, the study of this material was the focus of this study.

Fiedler (1967) mapped surficial deposits in the southeastern part of the present study area. His transportedregolith units consisted of scree, colluvium, and roundstone diamicton, the latter defined in a manner similar to the definition of Pierce (1966). Scree, derived from the Tuscarora Quartzite capping the mountains, occurs on the upper slopes. Colluvium is found on the lower slopes, and Fiedler noted that the boundary between colluvium and scree commonly is arbitrary. Colluvium usually occurs in hollows, whereas roundstone diamicton occurs on the lower ends of noses and locally on the tops of hills along the mountain foot slopes.

Houser (1980) mapped upland deposits in an area southeast of the present area using the map units 
colluvium, first-stage alluvium, and boulder streams. She defined colluvium as the slope deposits (mainly boulders and cobbles) between the ridge crests and the heads of the hollows on the ridge flanks. The mapping of these deposits was done on the basis of topographic criteria, using aerial photographs. First-stage alluvium consists of those deposits, partly alluvial in nature, which occur in the upper and middle parts of the hollows; these deposits are derived from colluvium upslope. Accumulations of first-stage alluvium funneled into steep-sided hollows are termed boulder streams.

Surficial deposits in the Catoctin-South Mountain area of Maryland as mapped by Godfrey (1975) included (1) boulder-covered slopes, (2) side-slope stone streams, (3) valley-bottom stone streams, and (4) mountain wash at the base of the mountains. Denny (1956, pl. 4) mapped the Genesee quadrangle of northern Pennsylvania. In the part of the map south of the glaciated area, his units included the following: (1) alluvium; (2) alluvial fans; (3) block fields; (4) thin mantles; and (5) periglacial deposits, where the latter was defined as rubble $3 \mathrm{~m}$ or more thick mantling lower valley walls. Hadley and Goldsmith (1963) included the following surficial units on their bedrock map of the Dellwood quadrangle, North Carolina: (1) alluvium; (2) alluvium and colluvium; (3) alluvial-colluvial fan deposits (younger and older); and (4) terrace deposits (older and younger).

From the above examples, some generalizations can be drawn concerning surficial mapping in upland areas of the unglaciated Appalachians. First, there has been an emphasis on boulder deposits, as these deposits are the ones that can be most easily mapped on the basis of surface appearance alone. Second, mapping commonly has been based on a combination of topographic and sedimentary criteria. Third, mapping units on mountain foot slopes frequently have combined colluvium and alluvium, owing to the difficulty of distinguishing them in this setting. Fourth, where age distinctions have been made, they commonly have been ones of relative age, for measurement of age in years or correlation with deposits of known age elsewhere rarely has been possible. Fifth, aside from those for alluvial deposits, the map units employed have been diverse. Each area has unique features, of course, so that units should vary. The great differences observed cannot simply be explained in this manner, however. Rather, the explanation probably is that there is no obvious manner in which to subdivide the transported regolith. Colluvium showing little or no fluvial influence gradually merges with alluvium; boulder deposits of one type commonly show gradual transitions to other types of boulder deposits and also to colluvium. Subdivisions based on age are also somewhat arbitrary, as deposits often seem to form a continuum from oldest to youngest rather than to fall into discrete age groups. Well-defined terraces in headwater areas are rare.

An effort was made to see if soils maps would aid in the mapping of surficial deposits. Soils maps of the study area (1981, Paul Swecker, U.S. Soil Conservation Service, unpub. data) crudely indicate bedrock and surficial conditions but are too generalized to portray many geomorphologically significant features. Soils of mountainous areas such as the study area commonly are mapped by the Soil Conservation Service in a generalized manner owing to their lack of agricultural potential.

\section{SURFICIAL DEPOSITS AND THEIR DISTRIBUTION}

The study area was selected for its accessibility, the variety of deposits that it appeared to contain, and the fact that previous work had been done in or near it. The relatively high road density not only provided accessibility but provided cuts which furnished information about the subsurface nature of the surficial sediments. Such exposures were particularly important since the stony nature of the soil commonly prohibited the use of hand augers.

Map units were selected on the basis of the following criteria. First, units based at least partly on sedimentary properties or on other field-determined characteristics contribute more information than those based solely on topography. Second, relative-age classifications, even though in most cases they represent the arbitrary division of a continuum, are useful and should be employed where possible. Third, the most useful information to be derived from surficial deposits is that which either bears on the manner in which the landscape has changed through time or provides evidence of Pleistocene glacial climates. Hence, where possible, units should be selected so as to convey information on these topics.

Map units 1,2, and 3 (fig. 3) indicate bedrock or residuum. Unit 1 indicates shale bedrock or residuum, chiefly on the Martinsburg Formation, and to a lesser extent on the Millboro Shale. Unit 2 indicates limestone bedrock or residuum, chiefly on the Ordovician limestones and the lower part of the Martinsburg Formation. Unit 3 indicates sandstone-rich residuum and slightly transported colluvium on dip slopes. This material is derived from Tuscarora Quartzite, Rose Hill Formation, "Keefer" Sandstone, and Rocky Gap Sandstone and overlies these formations as well as Huntersville Chert and Millboro Shale located downslope from them. This unit is made necessary by the areal extent of the dip slopes, where the recognition of transported regolith is particularly difficult. This 


\section{EXPLANATION}

\section{Residual Regolith}

Shale residuum or bedrock (Unit 1)

Limestone residuum or bedrock (Unit 2)

Sandstone residuum and slightly transported colluvium (Unit 3)

\section{Transported Regolith Colluvium}

Younger, less weathered sandstone-rich colluvium (Unit 4)

$\therefore \therefore$ Older, more weathered sandstone-rich colluvium (Unit 5)

\section{Transported Regolith Alluvium}

Fine-grained younger alluvium (Unit 6)

$\because \therefore \because \therefore$

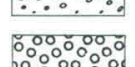
10

\section{Medium-grained younger alluvium (Unit 7)}

Coarse-grained younger alluvium (Unit 8)

Older, more weathered alluvium (Unit 9)

\section{Other Symbols}

$\triangle \quad$ Areas having abundant chert fragments 08

\section{Boulder streams and other dense} accumulations of large boulders

St Tuscarora Quartzite (Silurian)

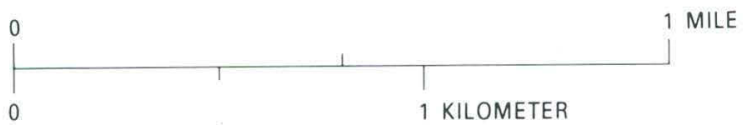

FIGURE 3.-Surficial geology of northern part of Eggleston quadrangle. Concentrations of boulders associated with older, more-weathered sandstone-rich colluvium are indicated by solid circles to stress rarity. Tuscarora Quartzite outcrop (St) is shown for outcrop slopes only. Map units, designated numerically, are discussed in greater detail in text. Letters $A-F$ indicate specific locations discussed in text. Southeast corner of map, south of Johns Creek Mountain, is after Fiedler (1967).

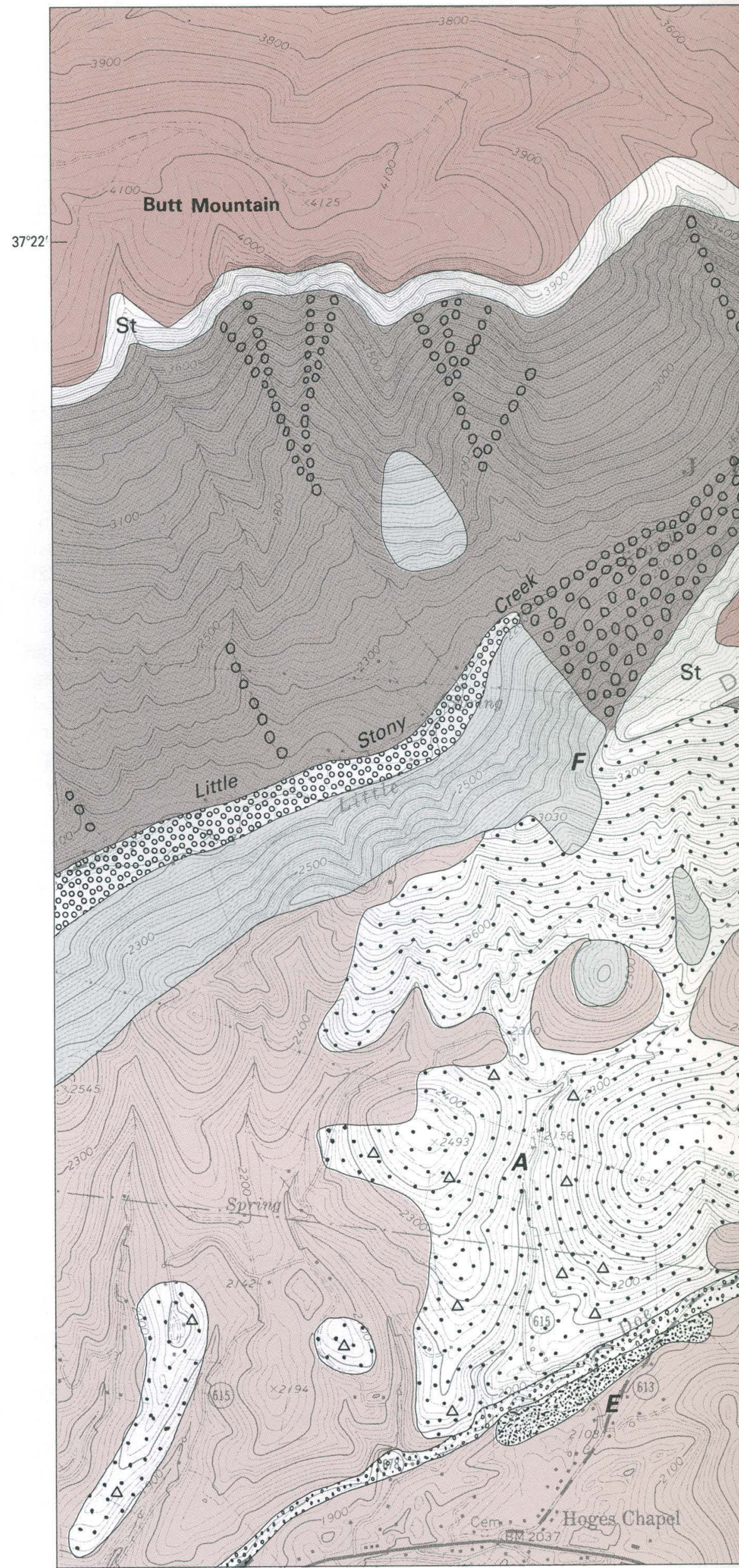



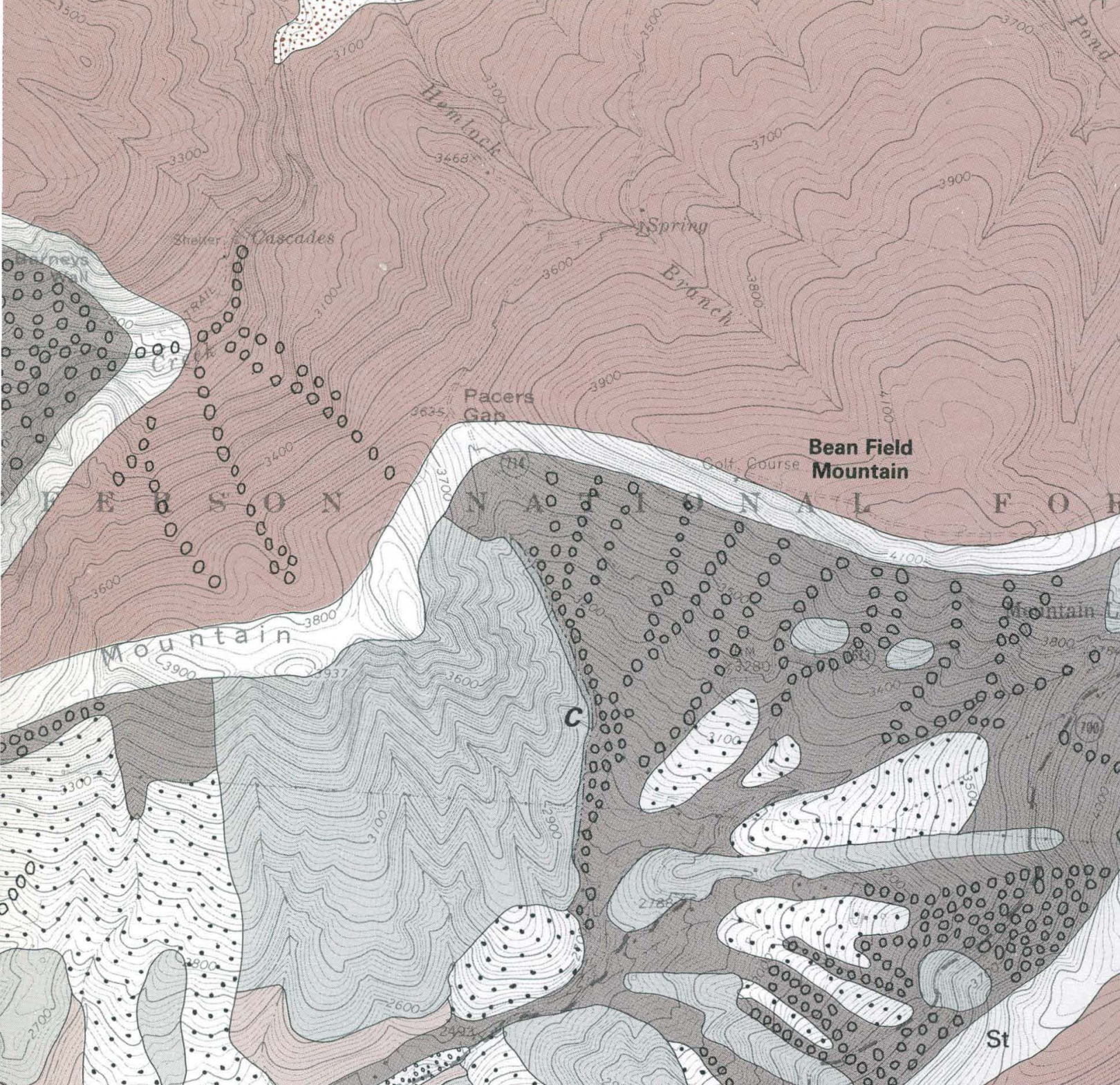

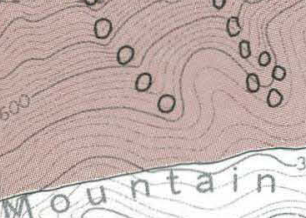
0 .

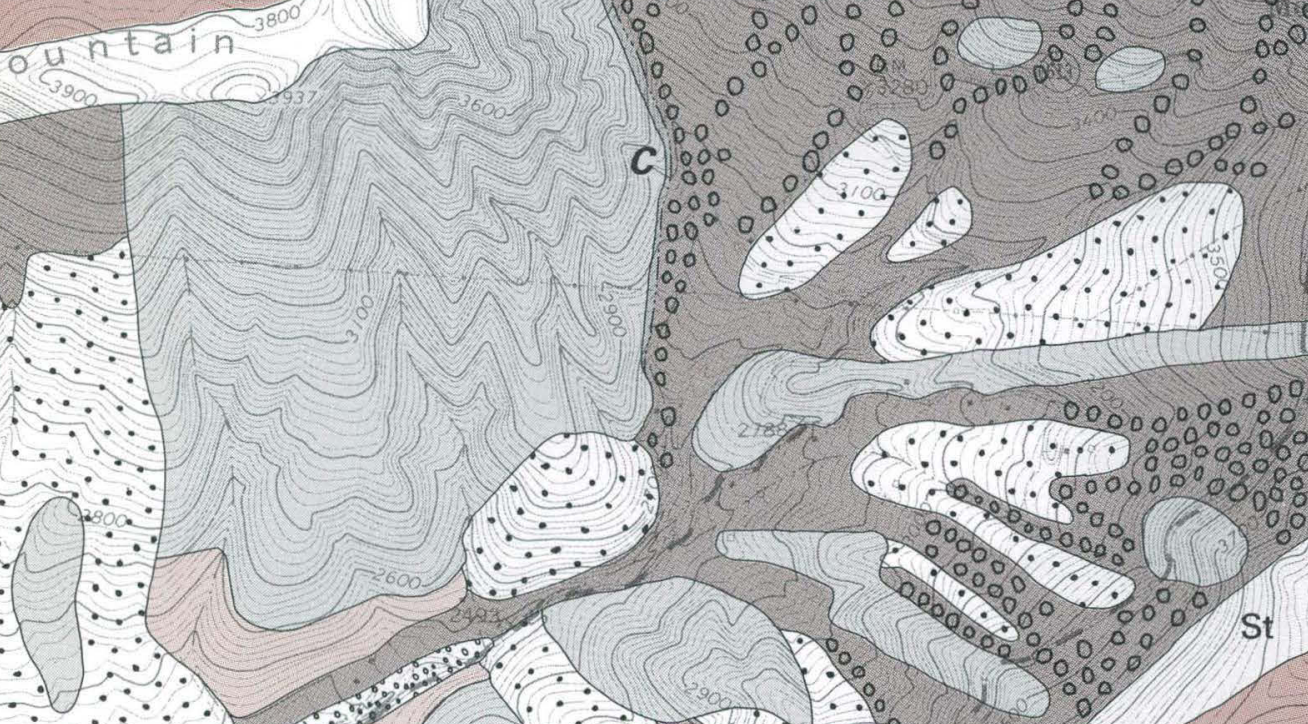

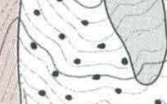

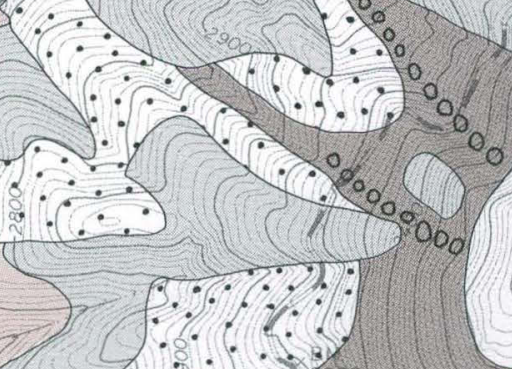

.

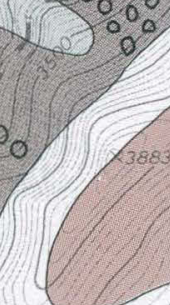

Bean Field

Mountain

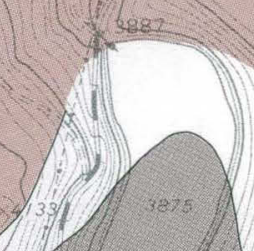

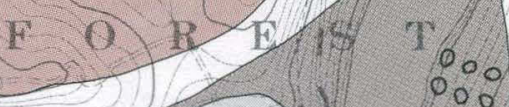

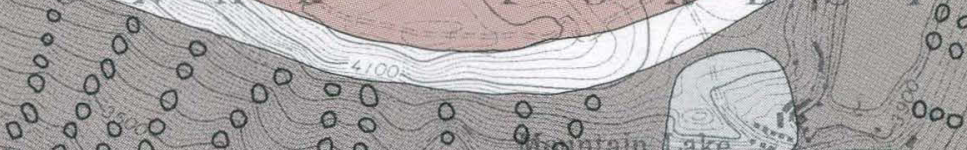

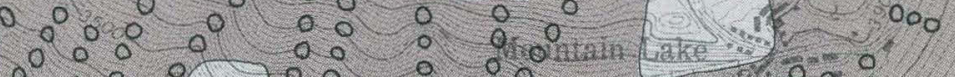
1000 
sandstone-rich regolith is most easily recognized on outcrop slopes, which are underlain primarily by shale. On dip slopes, largely underlain by sandstones, transport is more difficult to demonstrate. The texture of the surficial mantle generally is much finer than that on outcrop slopes; wide areas occur on dips slopes of the Tuscarora Quartzite where not a boulder can be seen. Locally, however, the surface may be just as bouldery as it is on outcrop slopes.

Units 4 and 5 (fig. 3), of most significance in this study, indicate transported sandstone-rich diamicton, here called colluvium, identified mainly on the basis of its content of Tuscarora or "Keefer" clasts. Unit 4 represents younger colluvium, as indicated by its relatively unweathered appearance, its location close to modern drainageways or on steep slopes, and its generally bouldery surface texture. Unit 5 is older colluvium, as indicated by its weathered appearance, its location on gently sloping noses, hilltops, or other positions above the modern drainageways, and its relative paucity of surface boulders. The colluvium reaches thicknesses of at least $8 \mathrm{~m}$, as shown by road cuts. Included as unit 5 deposits are areas where the colluvium has largely weathered away, being represented only by scattered Tuscarora and "Keefer" boulders overlying shale or limestone residuum. On soils maps such areas are shown as soil series derived from shale or limestone, but for the geomorphologist they indicate areas once covered with sandstone-rich colluvium.

The colluvium probably is produced by creep, slope wash, debris flows, and possibly by Pleistocene gelifluction. In piedmont areas, the colluvium often shows some fluvial influence, although even there it generally is poorly sorted and lacks stratification.

Units 6 to 9 (fig. 3) are alluvial deposits. Units 6 to 8 represent flood-plain deposits or low terraces, which have been subdivided according to texture. Unit 6 represents fine-grained alluvium, defined as consisting mainly of sand. Unit 7 represents medium-grained deposits defined as consisting of gravel but containing few large boulders. Unit 8 represents coarse-grained alluvium, defined by the presence of abundant large boulders. Unit 9 is older alluvium, identified by its height above modern drainageways and by a greater degree of weathering than that shown by alluvium of flood plains and low terraces.

Chert fragments shown on the map (fig. 3) are derived either from cherty Ordovician limestones or from the Huntersville Chert. Such fragments are locally abundant in both residual and transported regolith; these areas are indicated by the triangle symbols. The circles (fig. 3) indicate accumulations of Tuscarora or "Keefer" boulders, either as boulder streams or boulder fields. Rather than mapping boulder deposits as areal units, I show concentrations of boulders within the colluvium units because of the small areal extent of the deposits and because road cuts invariably show these deposits to overlie colluvium. The spacing of the circles indicates the continuity of the boulder cover. Where the circles are nearly touching, the cover is nearly continuous; where the circles are farther apart, the cover is somewhat less continuous.

Because the Tuscarora Quartzite supplies most of the sandstone clasts on the slopes, its outcrop belt shows the transport distance of the colluvium.

\section{DISTRIBUTION OF SURFICIAL DEPOSITS IN FOUR AREAS}

The study area was divided into four areas: Doe Creek drainage basin, Little Stony Creek basin below the Cascades, Little Stony Creek basin above the Cascades, and the north slope of Big Mountain.

DOE CREEK DRAINAGE BASIN

Included in this section is the area south of Johns Creek Mountain, which is not actually tributary to Doe Creek.

Doe Creek is located along the axis of the Mountain Lake anticline, flowing in a direction opposite to that of the plunge (figs. 2, 3). Boulders are supplied to the basin largely by Tuscarora Quartzite outcrops (fig. 4). Areas shown as Tuscarora on figure 3 consist of bedrock cliffs and ledges or of sandstone blocks. The overlying Rose Hill Formation also contributes rock debris to the slopes below but supplies few large boulders. The Juniata Formation, beneath the Tuscarora, locally crops out as cliffs and produces boulders, but typically exposures are poor and clasts derived from this formation are in the pebble- and cobble-size ranges. The Martinsburg Formation, because of its great thickness, underlies by far the greatest area of mountain slopes but generally is poorly exposed. Its contact with the Juniata Formation commonly is marked by a break in slope, the slope angle on the Martinsburg being somewhat lower. Mainly pebble- and cobble-size clasts are derived from the thin siltstones and sandstones that constitute the upper part of this formation, whereas the middle part, composed of fissile shale, weathers into small chips.

The residuum of the Martinsburg varies considerably according to the slope angle. Where angles are low, the shale weathers to a clay-rich, yellowish residuum 


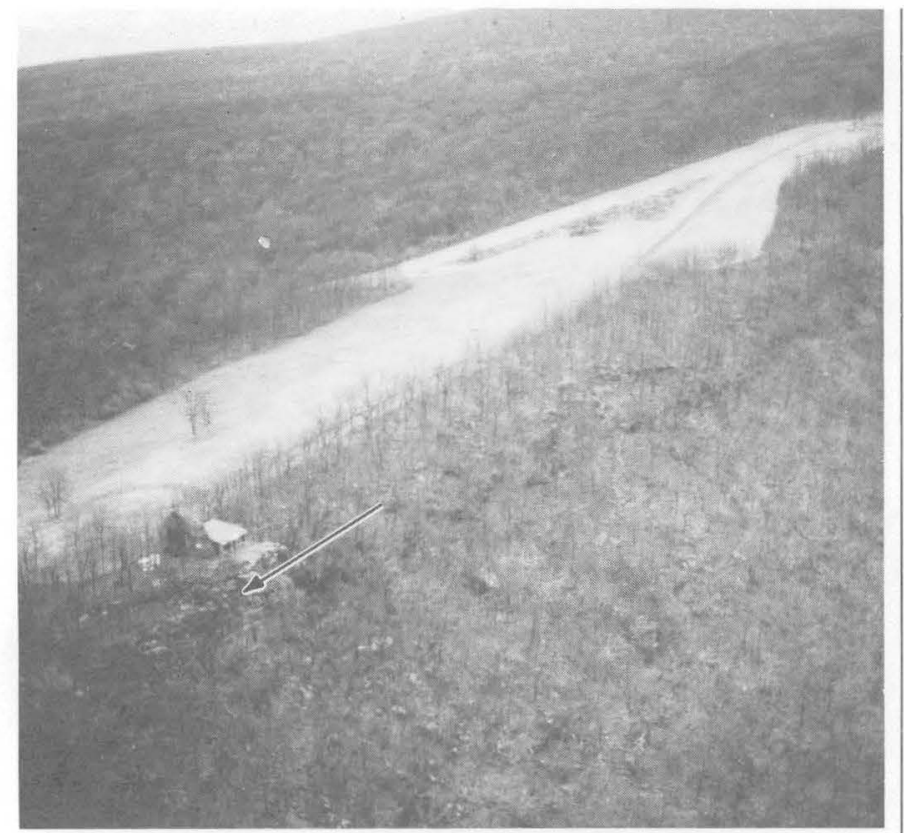

Figure 4.-Crest and south slope of Bean Field Mountain, looking east. Arrow indicates Tuscarora Quartzite outcrop, downhill from which boulders can be seen overlying the Juniata Formation.

that contains soft weathered shale chips and commonly is several meters thick. On steep slopes, however, where erosion is more rapid, fresh shale bedrock is overlain by a 15- to $30-\mathrm{cm}$-thick layer of hard gray shale chips in a dark matrix of fines.

Areas underlain by the limestone comprising the lower third of the Martinsburg Formation, or by the older Ordovician limestones, are characterized either by fresh rock outcrops or by reddish, clayey residuum. Outcrops most commonly occur on steep slopes, locally with detached limestone boulders which are never far from their source. Some of the Ordovician limestones are cherty, producing a mantle of pebble- to cobble-size angular blocks of chert. These limestones tend to erode into rounded hills having crests 50 to $140 \mathrm{~m}$ above adjacent streams, as shown in the southwest corner of the map (fig. 3).

Wide areas of Doe Creek basin are covered with sandstone-rich colluvium that has been transported a substantial distance (figs. 3, 5). On side slopes and other steep slopes the colluvial mantle generally is quite thin, but it is thicker (at least $8 \mathrm{~m}$ thick in road cuts) in hollows and on noses (fig. 6). Commonly the colluvium in hollows is younger than that on noses. Many noses, however, particularly those on shale bedrock, are devoid of any sandstone-rich colluvium (note noses labeled "SH" in fig. 5). Boulder streams and fields for the most part are confined to the areas of younger colluvium; exceptions are shown on figure 3.
(The map of the south side of Johns Creek Mountain is after Fiedler (1967), who did not map individual boulder streams. Hence, although no boulder streams are shown in this area, some may exist.) Generally the densest accumulations of boulders occur in moist hollows, as defined by the presence of yellow birch or rhododendron, most commonly on north-facing slopes. The south slope of Bean Field Mountain, however, shows many boulders despite the relative dryness of its hollows.

In areas distant from a sandstone source, older colluvium may be relatively thin and mixed with residuum. An exposure at $A$ on figure 3 shows a layer of sandy colluvium about $40 \mathrm{~cm}$ thick overlying clayey limestone residuum. This colluvium contains chert fragments, and the fairly sharp contact with the residuum is parallel to the modern hillslope surface. Note on figure 3 that older colluvium occurs somewhat farther from its source on limestone than it does on shale. As previously stated, colluvium has been removed from many shale noses, even from those relatively close to a modern source, although it survives on the tops of many limestone hills far from a present source, suggesting that colluvium is eroded from shale surfaces much more rapidly than from limestone surfaces. The older colluvium forms caps on hilltops but, more surprisingly, also occurs on relatively steep slopes. In some cases, such as that at location $A$ in figure 3 , the colluvium may be in transit down the slope, being continuously replenished by the erosion of a relatively thick colluvial cap on the hilltop. On the other hand, some old colluvium on relatively steep slopes has no such obvious source of replenishment and therefore must be relatively stable. The steepest slopes on which such deposits occur generally are about $15^{\circ}$; apparently where slope angles are greater the colluvium is eroded fairly rapidly. Similarly, on mountain slopes below present Tuscarora outcrops, colluvium on noses with slopes steeper than about $14^{\circ}$ generally is distinctly less weathered and is therefore presumably younger than colluvium on noses with slopes of $14^{\circ}$ or less.

One question of interest is the effect of bouldery colluvial mantles on the topographic development of the underlying limestone and shale. One might, for example, initially attribute the existence of the limestone hills to the protection provided by bouldery colluvial caps, but many limestone hills lack such caps. In addition, some locations that might, on the basis of their topography, be expected to have colluvial mantles, do not. For example, the lobate features at location $B$ (fig. 3) appear similar to colluvium-covered fans commonly found at the base of mountains capped by sandstone, but the limestone at this location is virtually devoid of sandstone clasts. Thus, the presence or absence of sandstone-rich colluvium does not seem to 


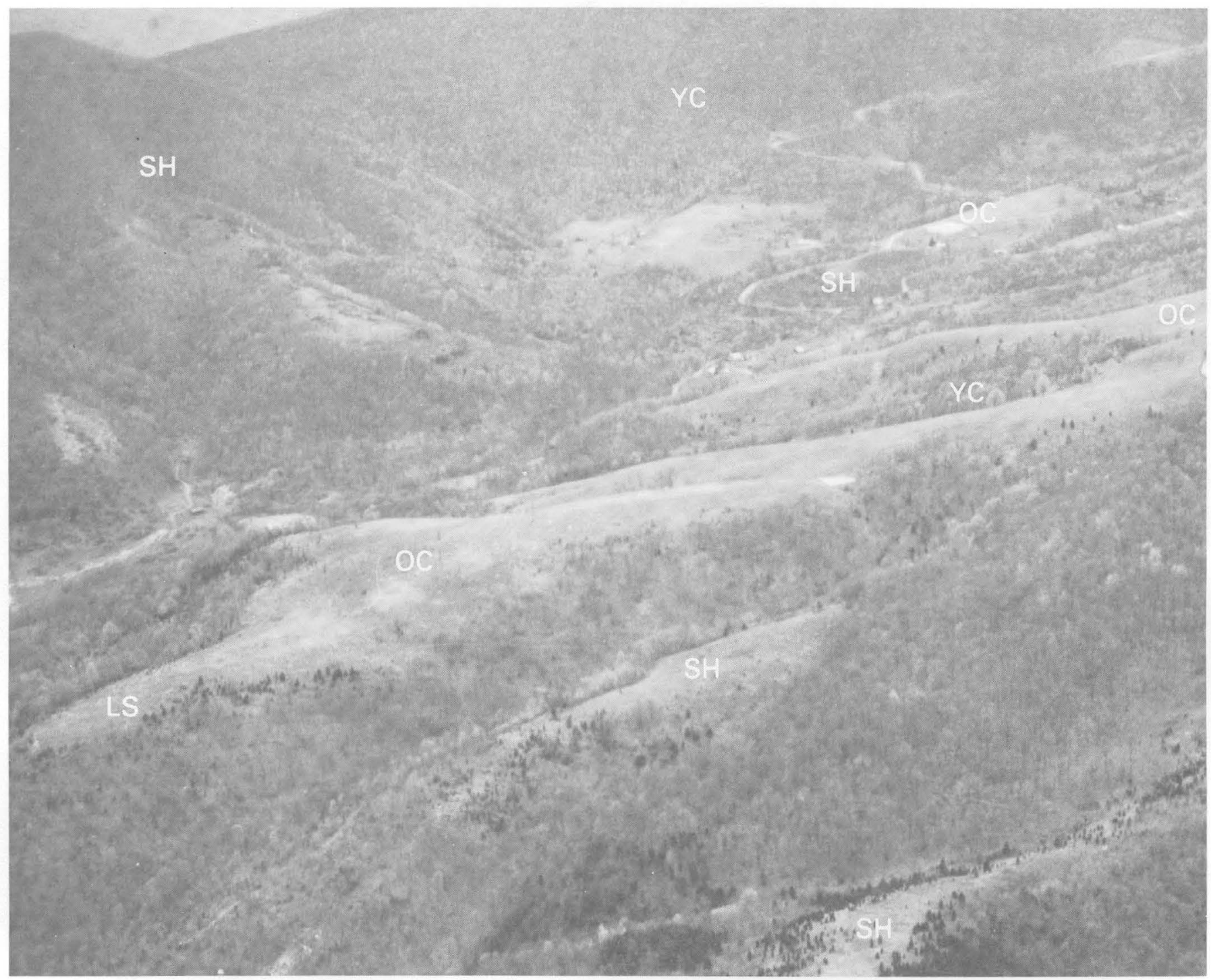

Figure 5.-Upper end of Doe Creek drainage basin, showing location of different types of regolith, looking northeast. Doe Mountain is in left background, Bean Field Mountain is in center background, and Salt Pond is out of view to the right. SH, shale bedrock and residuum; LS, limestone bedrock and residuum; YC, younger sandstone-rich colluvium; OC, older sandstone-rich colluvium.

exert much influence on the form of the landscape underlain by limestone.

In contrast to its lack of influence on limestone slopes, sandstone-rich colluvium seems to have a large effect on the form of areas underlain by shale. A large area on the south side of Doe Mountain is practically free of colluvium compared to the south flank of Bean Field Mountain which is covered by bouldery colluvium. The hollows on the unmantled shale slopes are deep and V-shaped (figs. 3, 7), whereas those on the boulder-clad slopes are much shallower and more likely to be asymmetric. This difference probably results from the effect of large boulders in the hollows. These boulders probably can be moved only by rare, catastrophic floods. Smaller, more common floods cannot move the boulders and are likely to cut down between the bouldery hollow fill and the less resistant shale side slope. The floor of the "channel" cut by such floods will, however, eventually be covered by boulders transported by creep from the adjacent boulder deposit or by the next catastrophic flood, so that subsequent lesser floods will in turn incise lateral to it. In this way the hollows migrate laterally (Mills, 1981). Where the shale is unprotected by boulders, however, such as on the south slope of Doe Mountain, the hollows are incised straight down, becoming large ravines.

The density of boulders on slopes appears to be controlled by the exact location of the Tuscarora Quartzite outcrop with respect to the mountain crest. Where the entire thickness of the Tuscarora crops out 


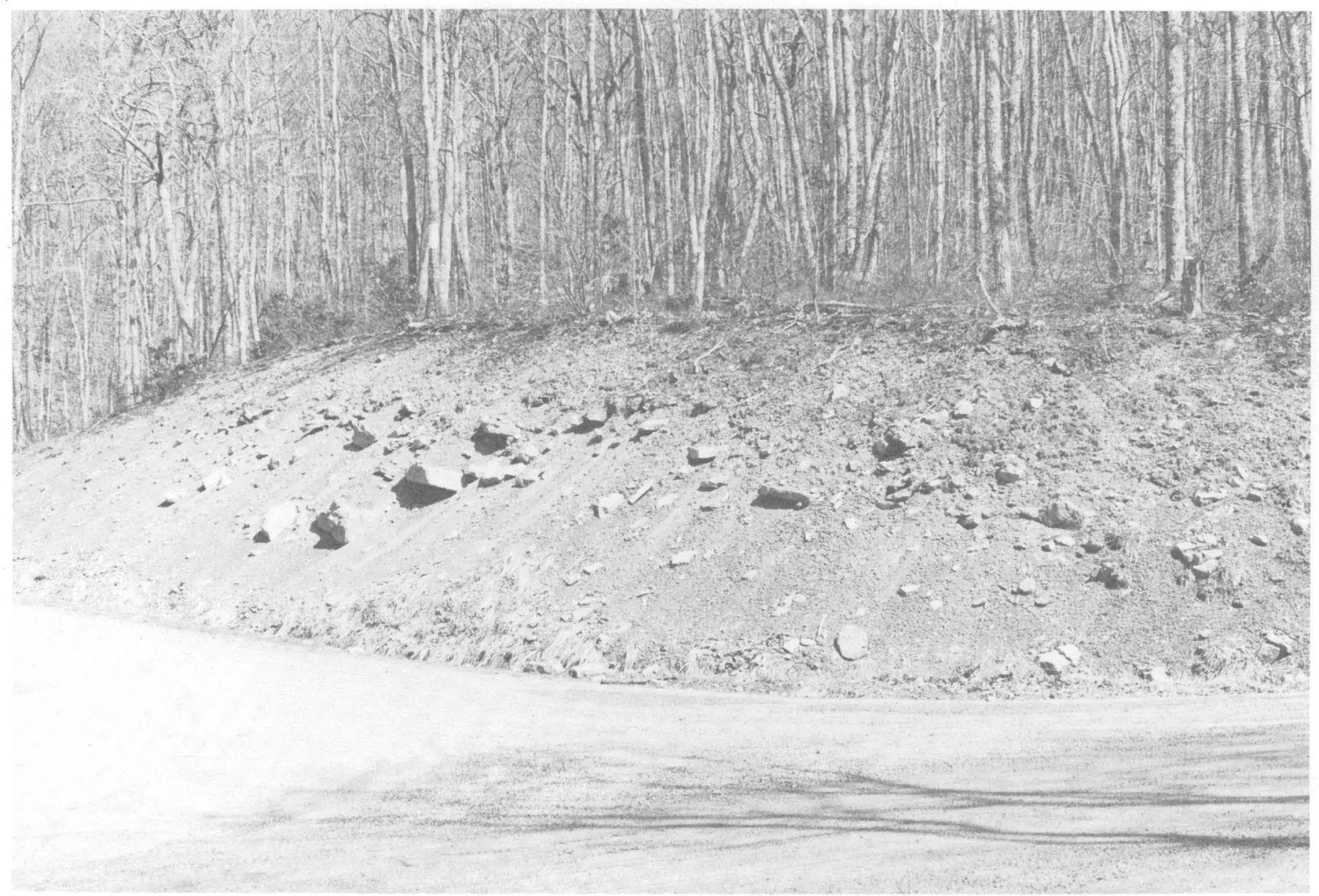

Figure 6.-Road cut through shale nose capped by sandstone-rich colluvium, along south flank of Bean Field Mountain.

on the flank of the mountain (fig. $8 A$ ), as on Bean Field Mountain, the slopes have abundant Tuscarora boulders. Where the crest is at or near the base of the Tuscarora, however (fig. $8 B$ ), few boulders are supplied to the outcrop slope. For the most part, the crest of Doe Mountain is like that shown in figure $8 B$. Which of the configurations shown in figure 8 prevails at a given locality seems to depend in part upon the resistance of the upper Juniata Formation at that locality. Where the Juniata is more resistant (due to thicker bedding and perhaps to a higher proportion of sandstone), the configuration is like that shown in figure $8 B$, for under such circumstances the Juniata is capable of holding up the mountain crest; but the boulders derived from it disintegrate a short distance below the outcrop, so that the hollows lack boulders. Where the Juniata Formation is less resistant, however, it is unable to hold up the crest, and the outcrop slope retreats until it undermines the Tuscarora Quartzite, which then crops out mainly on the outcrop slope, as shown in figure $8 \mathrm{~A}$. In this case, plentiful resistant boulders are supplied to the hollows which thus tend to migrate laterally.
The phenomenon of lateral planation produced by the effects of boulder armoring applies not only to hollows, but also to small stream valleys, such as the one occupied by an intermittent stream south of Pacers Gap, between Doe and Bean Field Mountains (fig. 3, loc. C). Tuscarora boulders are rare on the east flank of Doe Mountain, except for the slopes nearest Pacers Gap. In contrast, the southwest flank of Bean Field Mountain is covered with boulders. Because of this difference, the intermittent stream shown at locality $C$ in figure 3 apparently has migrated westward toward the base of Doe Mountain.

Topographic evidence suggests that some of the sandstone-rich colluvium must antedate the modern geomorphic system. First, limestone hilltops capped by this material have as many as five closed $20-\mathrm{ft}(6.1-\mathrm{m})$ contours, meaning that at least $100 \mathrm{ft}(30.5 \mathrm{~m})$ of bedrock erosion has taken place since deposition of the colluvium. Second, the colluvium in the southwestern part of the map must have been derived from a former southwestern extension of the Tuscarora Quartzite outcrop on Doe Mountain (figs. 3, 9). Thus, for example, 


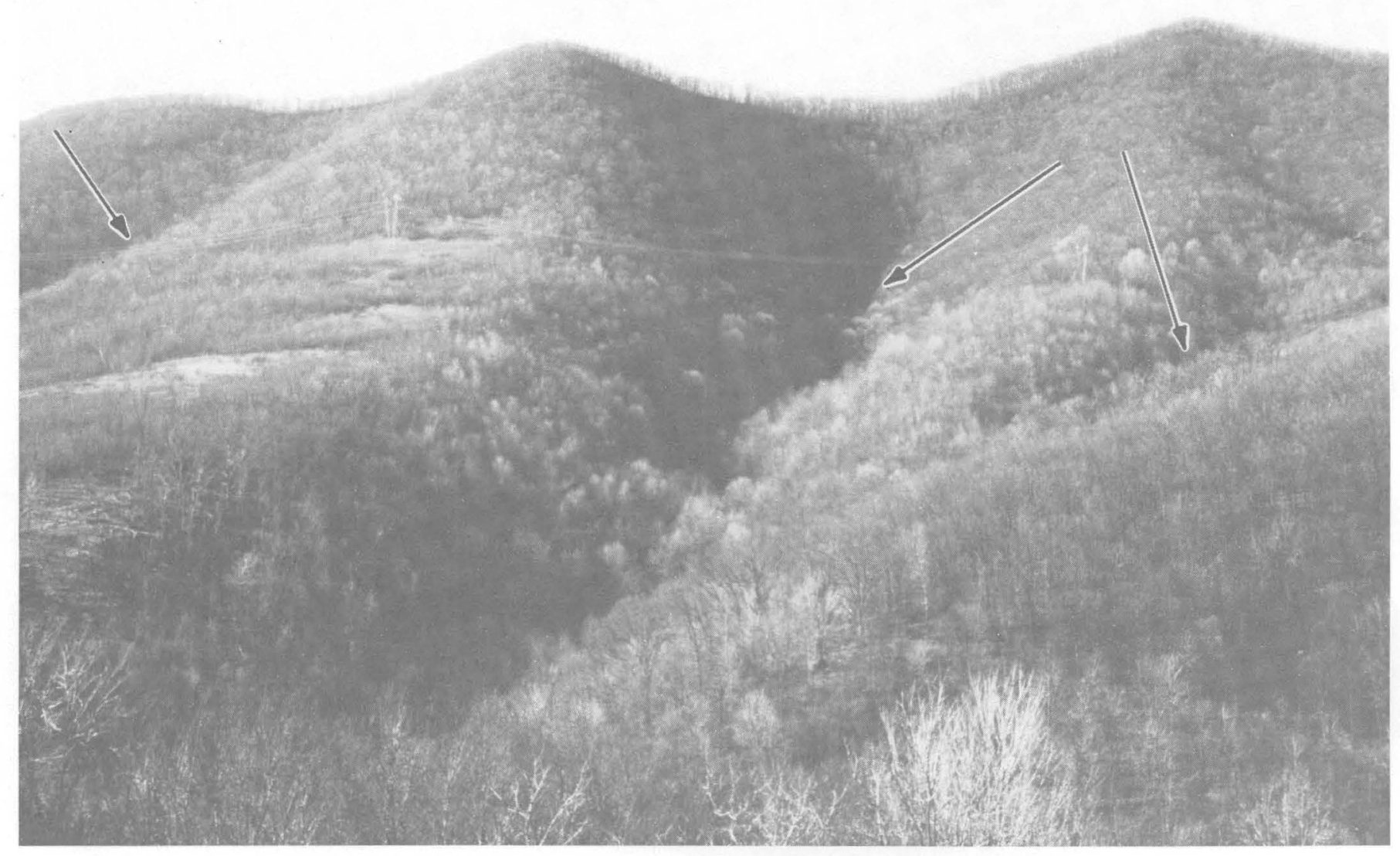

Figure 7.-South slope of Doe Mountain. Arrows indicate V-shaped hollows (ravines).

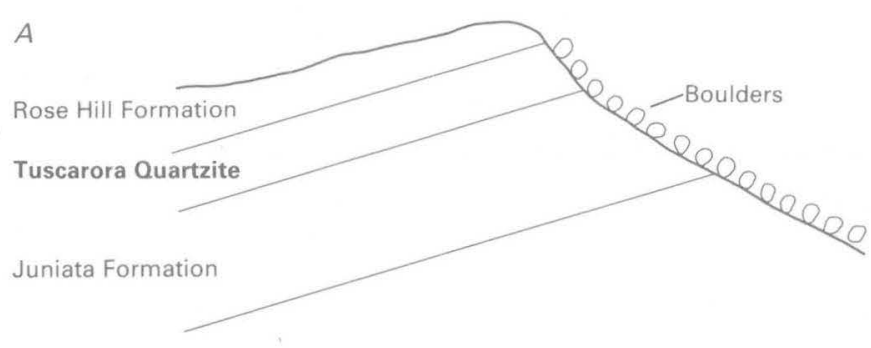

Martinsburg Formation

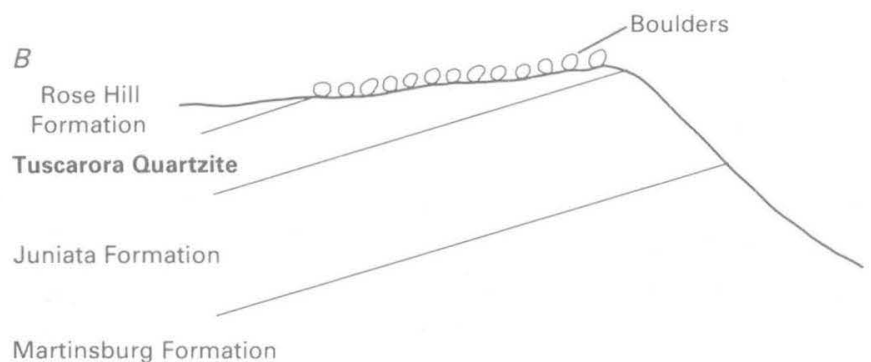

FIGURE 8.-Boulder abundance as it relates to the location of Tuscarora Quartzite outcrops: $A$, When Tuscarora outcrop is completely on outcrop slope, boulders on that slope are plentiful; $B$, When Tuscarora outcrop is mainly on dip slope, few boulders are on outcrop slope. since the colluvium capping the elongate hill in the extreme southwestern part of the map (fig. 3) was deposited, the Tuscarora outcrop must have retreated more than $2 \mathrm{~km}$. On the basis of data from many parts of the world, Young (1974) suggested that the rate of cliff retreat on hard sedimentary rocks ranges from 100 to $1,000 \mathrm{~mm} / 1,000 \mathrm{yr}$; these rates suggest an age for this deposit of between 2 and 20 million years. A third example shows that even on hillslopes close to a caprock, colluvial deposits may be relatively old. At location $D$ on the south side of Johns Creek Mountain (fig. 3), Tuscarora clasts must have been derived from an outcrop directly up the slope. But the southern contact of the Tuscarora outcrop on Johns Creek Mountain is separated from the slope above location $D$ by a shallow depression (fig. 3), so that at present no Tuscarora clasts can be supplied to this slope. Indeed, this slope is almost totally devoid of Tuscarora boulders. Thus, the colluvium at location $D$ must be relict from a time when the Tuscarora contact was located somewhat farther south. These examples, besides demonstrating the antiquity of the deposits, also show how older colluvial deposits can provide details of landscape evolution. 


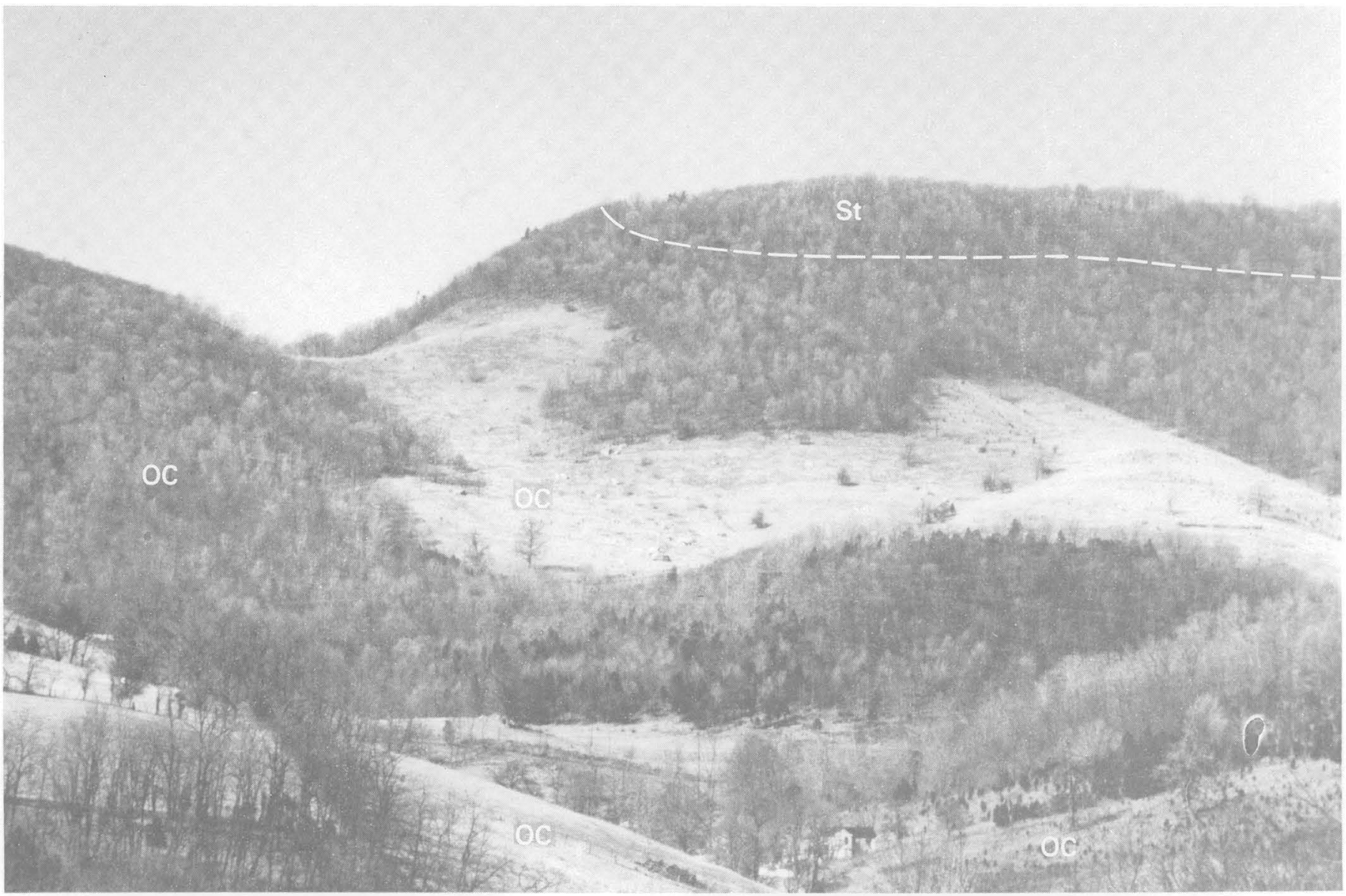

FIGURE 9.-Southwest end of Doe Mountain, showing relict sandstone-rich colluvial deposits. Dashed line shows approximate southwest limit of Tuscarora Quartzite (St) outcrop. Southwest of gap on skyline, older colluvium (OC) has no present sandstone source upslope from it and hence must be a relict deposit from a time when there was such a source.

Doe Creek possesses a narrow flood plain throughout its length. Only one deposit was found that might be a terrace deposit (fig. 3, loc. E). Well-rounded clasts were found on the lower slopes of the hill immediately north of the stream at $E$ and may be former Doe Creek alluvial clasts. The deposit itself, however, is colluvium, as shown by the fact that its contact with the underlying residuum is steeply sloping and parallel to the hillslope surface.

\section{LITTLE STONY CREEK BASIN BELOW THE CASCADES}

As a consequence of its steep gradient, Little Stony Creek below the Cascades is a powerful stream. The difference in gradient above and below the Cascades is marked. Above, the stream flows $5.1 \mathrm{~km}$ between the $3,200-\mathrm{ft}(976-\mathrm{m})$ and 3,000-ft $(915-\mathrm{m})$ contours, for an average gradient of 0.012 . Below, it flows $2.5 \mathrm{~km}$ between the 2,800-ft $(854-\mathrm{m})$ and 2,200-ft $(671-\mathrm{m})$ contour lines, for an average gradient of 0.073 , six times as steep. The upper part of the reach shown on figure 3 contains many boulders $5 \mathrm{~m}$ or more in diameter, although most of these probably are only very rarely moved. Even in the downstream part of the reach shown on figure 3 boulders are much larger and more numerous than those in Doe Creek.

Probably because of the steep walls of the stream valley, the Tuscarora outcrops at the crests are being rapidly undermined, and as a result almost all the slope area is covered with boulders and sandstone-rich colluvium. The boulder streams on the walls of this valley are the steepest I observed; the slope of one stream was measured at $36^{\circ}$ (figs. 10, 11). These streams may be moving, as some of them lack forest cover over short reaches. At no other location in the study area did I observe scree without forest cover. The boulder streams are about $15 \mathrm{~m}$ wide, and they die out near the base of the steeper, upper slopes. Below these slopes, boulders in hollows are fewer and smaller.

The southwest nose of Doe Mountain lacks Tuscarora outcrops southwest of about the 3,380-ft (1,030$\mathrm{m})$ contour (fig. 3). Southwest of this point, therefore, 


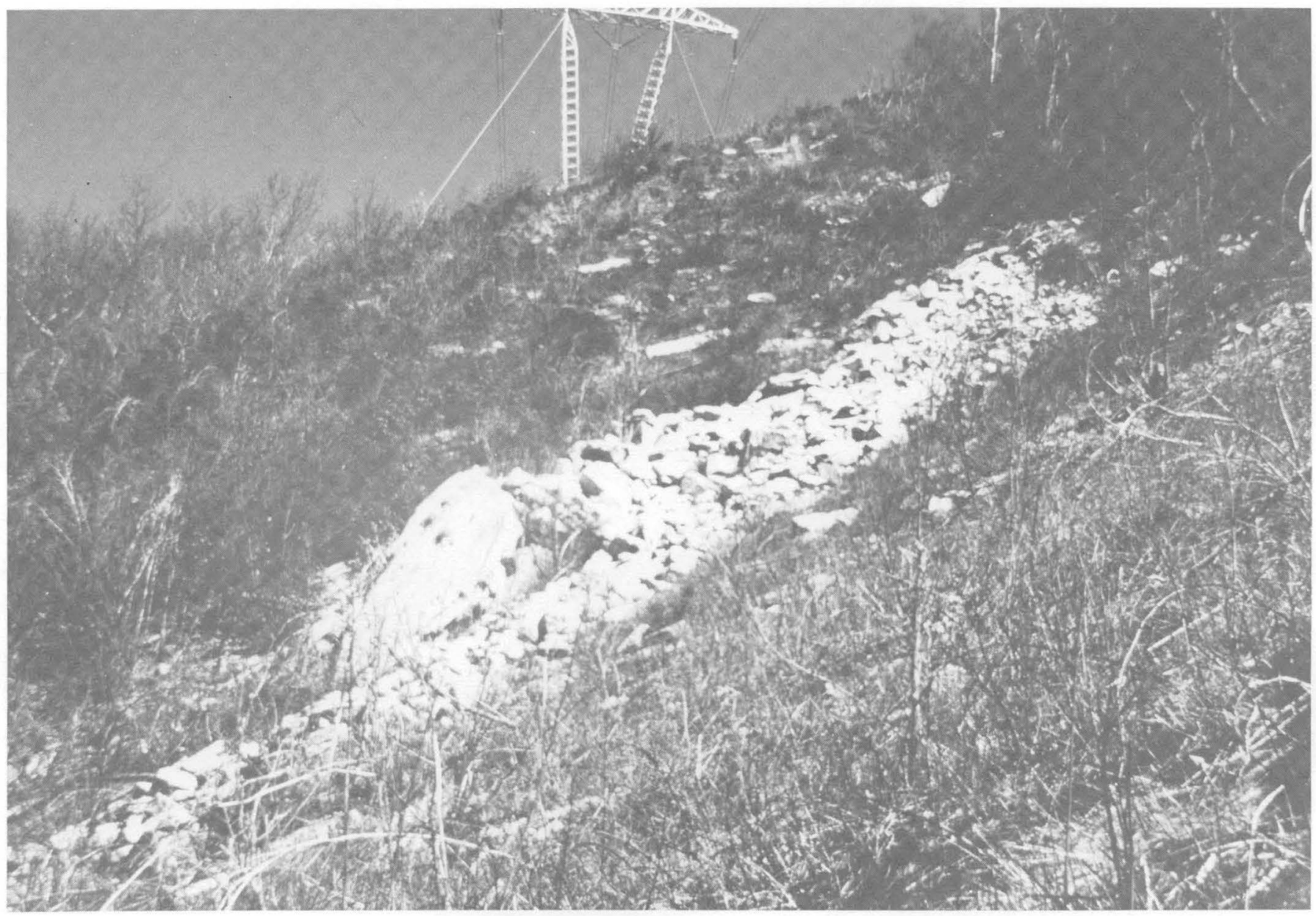

FIGURE 10.-Boulder stream on northwest flank of Doe Mountain, northeast of location $F$ on figure 3 . Boulders are predominantly Tuscarora Quartzite. This area has been cleared of trees because of location along powerline route; in natural state, boulder streams are obscured by trees growing on or adjacent to them.

the northwest flank is almost without boulders, whereas northeast of this point it is covered with boulders. This difference in boulder armoring has produced a pronounced reentrant in the flank of Doe Mountain southwest of location $F$ (fig. 3), where sandstone debris from Butt Mountain has forced Little Stony Creek against the unprotected northwest flank of Doe Mountain, greatly steepening this shale slope: The hillslope here has an average gradient of $36^{\circ}$ over a vertical distance of $300 \mathrm{~m}$ (fig. 12). Unlike the gentler southeast flank of the mountain, the oversteepened northwest flank southwest of $F$ has retained no relict sandstone-rich colluvium. At locality $F$ (fig. 3 ) a thick sandstone bed of the upper Juniata Formation is being rapidly undermined by the retreat of the shale slope. Dislodged boulders roll most of the way down the slope. The rapidity of this process is shown by the number of scarred trees. Of 30 trees inspected immediately downslope from the Juniata sandstone cliff, 23 had scars on their uphill side. The lack of deep, V-shaped hollows on this slope, in contrast to the southeast flank of Doe Mountain, appears to result from the extreme degree of undermining and consequent high rate of slope retreat.

The relatively flat mountain tops and dip slopes, held up by horizontal or gently dipping sandstones, generally have a finer surficial mantle than do the outcrop slopes. The top of Doe Mountain, however, is particularly bouldery, and has several boulder streams.

\section{LITTLE STONY CREEK BASIN ABOVE THE CASCADES}

The surficial geology of the upper basin of Little Stony Creek is shown in figure 13. The "Keefer" Sandstone underlies dip slopes in this synclinal valley and generally is characterized by a fine-textured surficial mantle. Exceptions include the boulder field along Pond Drain in the southeast corner of figure 13 and the boulder streams on the south flank of Big Mountain. 


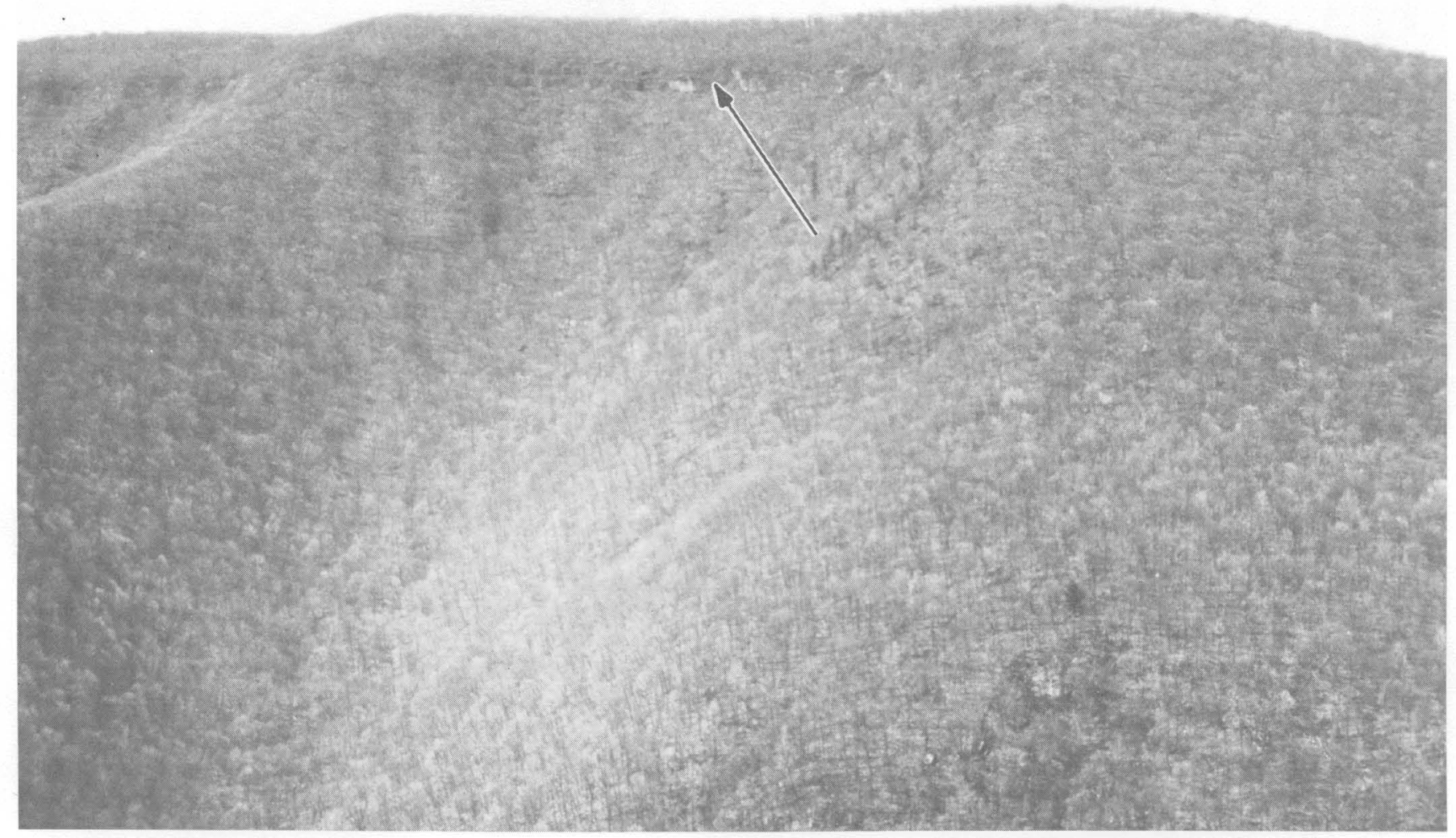

FIGURE 11.-South flank of Butt Mountain as viewed from crest of Doe Mountain. Outcrop visible near crest is Tuscarora Quartzite, indicated by arrow. Boulder streams with slopes of as much as $36^{\circ}$ occur in the shallow drainageways below the Tuscarora outcrop.

The carbonate-cemented Rocky Gap Sandstone is readily disaggregated by leaching in this climate. At many locations it is decomposed to sand for a depth of several meters, becoming oxidized to brown and orange colors; locally, fractures in the weathered rock are filled with manganese and iron oxides. The decomposed rock is easily eroded, the gullies in some locations thus furnishing a voluminous supply of sand to foot slopes and stream systems. Despite its susceptibility to weathering, however, The Rocky Gap Sandstone forms flatirons on some dip slopes, especially on the south flank of Big Mountain (figs. 13, 14). The flatirons are characterized by knobs at their apexes that provide the only prominent outcrops of the sandstone, and large boulders occur immediately downslope from these outcrops. On the south side of Little Stony Creek, where the dip is more moderate, the Rocky Gap Sandstone erodes into spurs with knobs at their tops rather than into flatirons. The localized resistance of this unit apparently derives from a coarser grain size and a high iron content. Eckroade (1962) noted that numerous ferruginous granule conglomerates occur throughout the Rocky Gap Sandstone. Knobs at the top of flatirons or on spurs largely consist of this lithology; the iron-oxide cement makes the conglomerates relatively resistant to erosion. Many clasts in the upper reaches of Little Stony Creek are derived from this ferruginous conglomerate.

The Huntersville Chert has little topographic expression in the area, although it does furnish blocky chert pebbles and cobbles to the surficial mantle on parts of the foot slopes, which it generally underlies. The Millboro Shale commonly underlies lower slopes and flood plains, but locally it forms highly dissected areas of small, steep-sided hills, usually not more than $30 \mathrm{~m}$ high, such as the area north of lower Laurel Creek in the southwest part of figure 13. No transported sandstone regolith is found on these steep shale hills, probably because of the rapid surface erosion.

Because of the gentle slope of Little Stony Creek above the Cascades, clasts larger than cobble size are rarely seen in the stream channel, and the surfaces of 


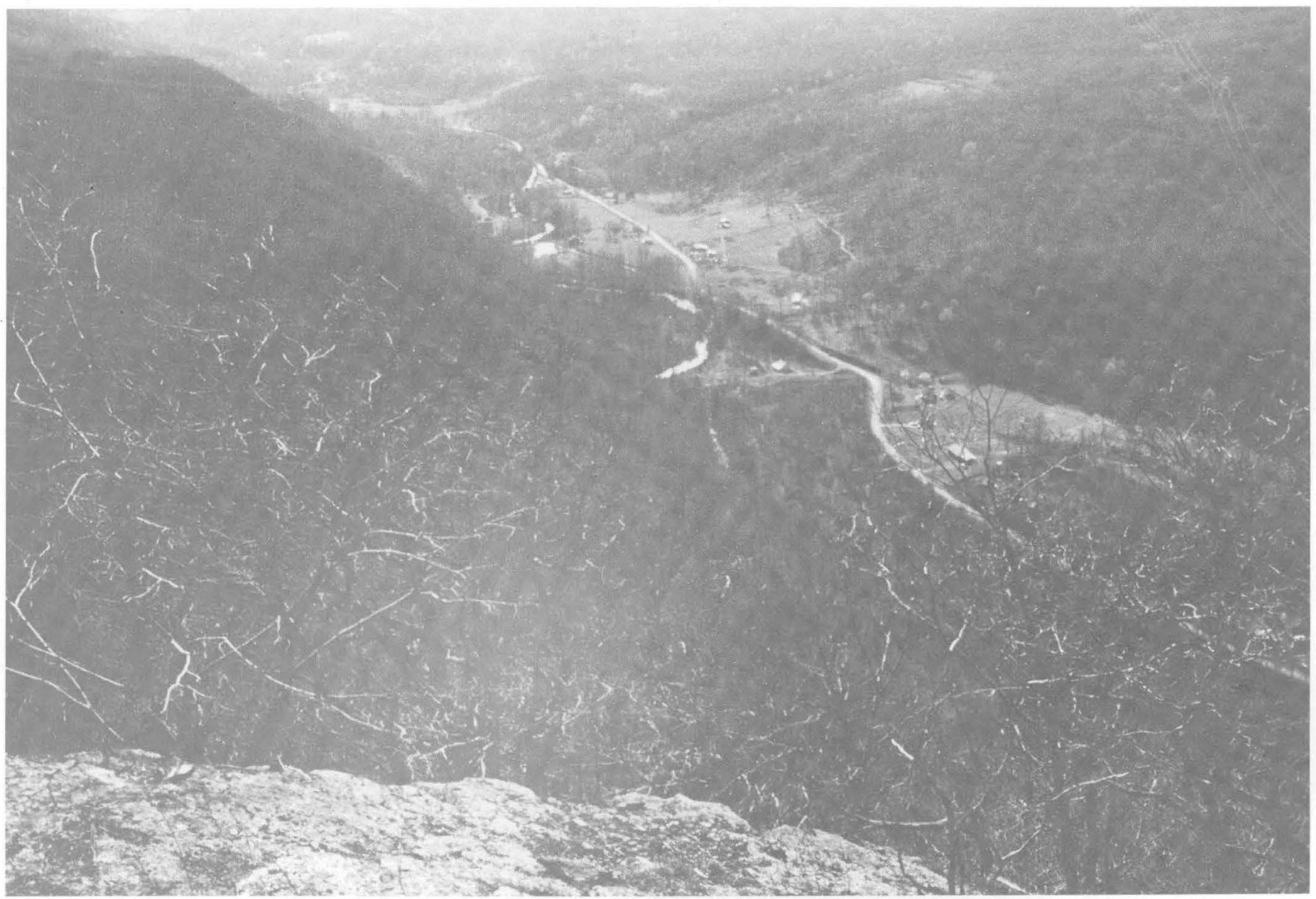

Figure 12.-View down steep northwest flank of Doe Mountain, from crest of Doe Mountain. Stream in valley is Little Stony Creek.

the flood plain and low terraces are composed largely of sand. As shown in figure 13, the flood plain is somewhat broader than that of other streams in the area, with its very flat surface giving rise to many boggy areas. Despite the flood-plain width, however, the depth of fill does not appear to be great, as indicated by several cuts in lower terraces that expose bedrock. For example, at location $G$ (fig. 13), two deposits of low terraces were exposed by a road cut. The lower terrace is about 1.5 to $2 \mathrm{~m}$ above the present flood plain, and the higher one about $3 \mathrm{~m}$. The higher terrace shows a sand layer about $75 \mathrm{~cm}$ thick overlying a gravelly layer about $50 \mathrm{~cm}$ thick. Beneath the gravel is a transitional layer about $30 \mathrm{~cm}$ thick, in which sandstone alluvial clasts are mixed with fragments of Millboro Shale, and underlying this layer is weathered Millboro Shale. The soils on these terraces appear to be very young.

Several alluvial surfaces are found south of the Little Stony Creek flood plain (fig. 15). Where Pond Drain debouches onto the floor of this valley, an alluvial fan has been built (figs. 13,15 ) which is generally sandy but contains gravel. Several low, fairly young terraces can be observed on this fan. The fan surface is characterized by many Eastern white pines in contrast to the older surfaces to the east, which are covered mainly by hardwoods. The alluvial surface to the east, roughly $5 \mathrm{~m}$ above the Pond Drain fan, appears to have moreweathered sediments, probably consisting of older deposits of Pond Drain, of the headwaters of Little Stony Creek, and of the smaller intermittent streams between these streams. This surface is more gravelly than that of the Pond Drain fan. Stream gravels cemented with iron oxide were seen at one location on this surface, the iron perhaps having been obtained from the Rocky Gap Sandstone immediately upslope. A higher surface, at least $10 \mathrm{~m}$ above the Pond Drain fan and possibly alluvial in origin, occurs to the west of the fan (figs. 13, 15). This surface is about 18 to $24 \mathrm{~m}$ above the level of Little Stony Creek. It is cut across the Huntersville Chert and Millboro Shale, and has a gradient similar to that of Pond Drain fan, but it lacks a cover of alluvium. Widely scattered rounded sandstone 
clasts suggest that the surface may once have had such a cover, however. I have classified it as an alluvial surface mainly on the basis of its morphology and its proximity to a younger alluvial surface. A similar, smaller surface to the west (fig. 13) probably is the product of an ephemeral stream.

Two holes were drilled with a hand auger on the fan south of Laurel Creek (loc. $H$, fig. 13). The first penetrated $200 \mathrm{~cm}$, and the second $240 \mathrm{~cm}$, before striking a sandstone cobble. The fan thus appears to consist largely of sand, probably eroded from the Rocky Gap Sandstone upslope. Although part of this sand was transported by Laurel Creek, much probably was transported downslope by small ephemeral streams. Large sandstone clasts are found on the surface only near Laurel Creek.

Near the base of the south flank of Big Mountain, fan-shaped features are located at the mouths of ephemeral or intermittent streams that flow between flatirons of Rocky Gap Sandstone (fig. 13). The surfaces of these fans display scattered "Keefer" or Tuscarora Quartzite boulders, indicating that the fans were formed by the streams that debouche near them. The soils on these fans consist mainly of residuum, but on the basis of the sandstone boulders the fan surfaces are classified as older, sandstone-rich colluvium (fig. 13). Several pieces of evidence suggest that these fan surfaces are largely relict. First, the modern streams flow along the margins of the fans or else are incised into them (fig. 13). Second, the boulder streams between the Rocky Gap Sandstone flatirons, which probably supplied Tuscarora or "Keefer" boulders to the fans, now terminate far short of the fans. Third, the surfaces of some fans are as much as $15 \mathrm{~m}$ above the flood plain of Little Stony Creek. These fans probably are composed mainly of shale bedrock, the protection provided by the former bouldery mantle having preserved their surfaces.

\section{NORTH SLOPE OF BIG MOUNTAIN}

Because of the extensive outcrops of Tuscarora Quartzite and "Keefer" Sandstone, the north slope of Big Mountain is extremely bouldery and has boulder streams larger than those elsewhere in the study area. The largest streams are in the moistest locations and are covered with dense growths of rhododendron. Generally, the boulder streams die out several hundred meters below the lowest orthoquartzite outcrop. Boulder streams (fig. 16) and colluvium (fig. 17) are woll exposed in cuts along Rocky Mountain Road (U.S. Forest Service 734), which runs along the north side of Big Mountain at an elevation of about $975 \mathrm{~m}$ (not shown on fig. 13).

The northern foot slopes of Big Mountain, though having few large boulders, are almost completely cov- ered with a relatively young stony mantle containing many orthoquartzite cobbles and small boulders. This colluvial apron extends northward all the way to Stony Creek which it has probably pushed against the north wall of its valley, resulting in an absence of terraces. The load of Stony Creek is coarse, probably because of the proximity of the stony colluvial apron. Although by no means as bouldery as the flood plain of Little Stony Creek below the Cascades, the flood plain of Stony Creek has been classified as coarse grained (fig. 13).

\section{DISCUSSION}

I suggest herein that the older sandstone-rich colluvium overlying limestone was transported laterally to its present position rather than being let down vertically as the limestone beneath it dissolved. The manner in which this colluvium formed bears on the age of the deposits, for surficial sediments can be let down great vertical distances over soluble bedrock, resulting in the preservation of very old deposits. Pierce (1965), for example, reported a lignitic deposit of Late Cretaceous age overlying carbonate residuum in the Great Valley of southern Pennsylvania. Unlike Pierce's Cambrian bedrock section, however, in the present study area such letdown seems unlikely because the Ordovician limestones upon which the colluvium rests originally were separated from the overlying Tuscarora Quartzite and "Keefer" Sandstone by the great thickness of the Martinsburg Formation. Clasts eroded from the Silurian sandstones would have been deposited on the insoluble Martinsburg siltstones and shales. How the sandstone clasts could have been let down vertically while hundreds of meters of clastic rock were eroded from beneath them is very difficult to imagine. Lateral transport would have been almost inevitable under such circumstances. A related question is why the colluvium appears to be preserved longer over limestone than over shale. Because limestone undergoes mainly subsurface erosion and shale mainly surface erosion, deposits overlying shale are likely to be eroded away much more rapidly than those over limestone.

The study of upland transported regolith reveals new ways in which bedrock affects topography, particularly ways involving the protective role of large sandstone boulders. For example, the forms of hollows incised into Martinsburg shale on mountain flanks vary considerably according to whether the flank possesses a boulder mantle or not, which in turn depends upon seemingly unimportant geologic factors near the mountain crest. In addition, as shown by the northwest flank of Doe Mountain, the presence of a boulder mantle may greatly affect the amount of retreat that a mountain slope undergoes; thus, the concept of the protective role of 


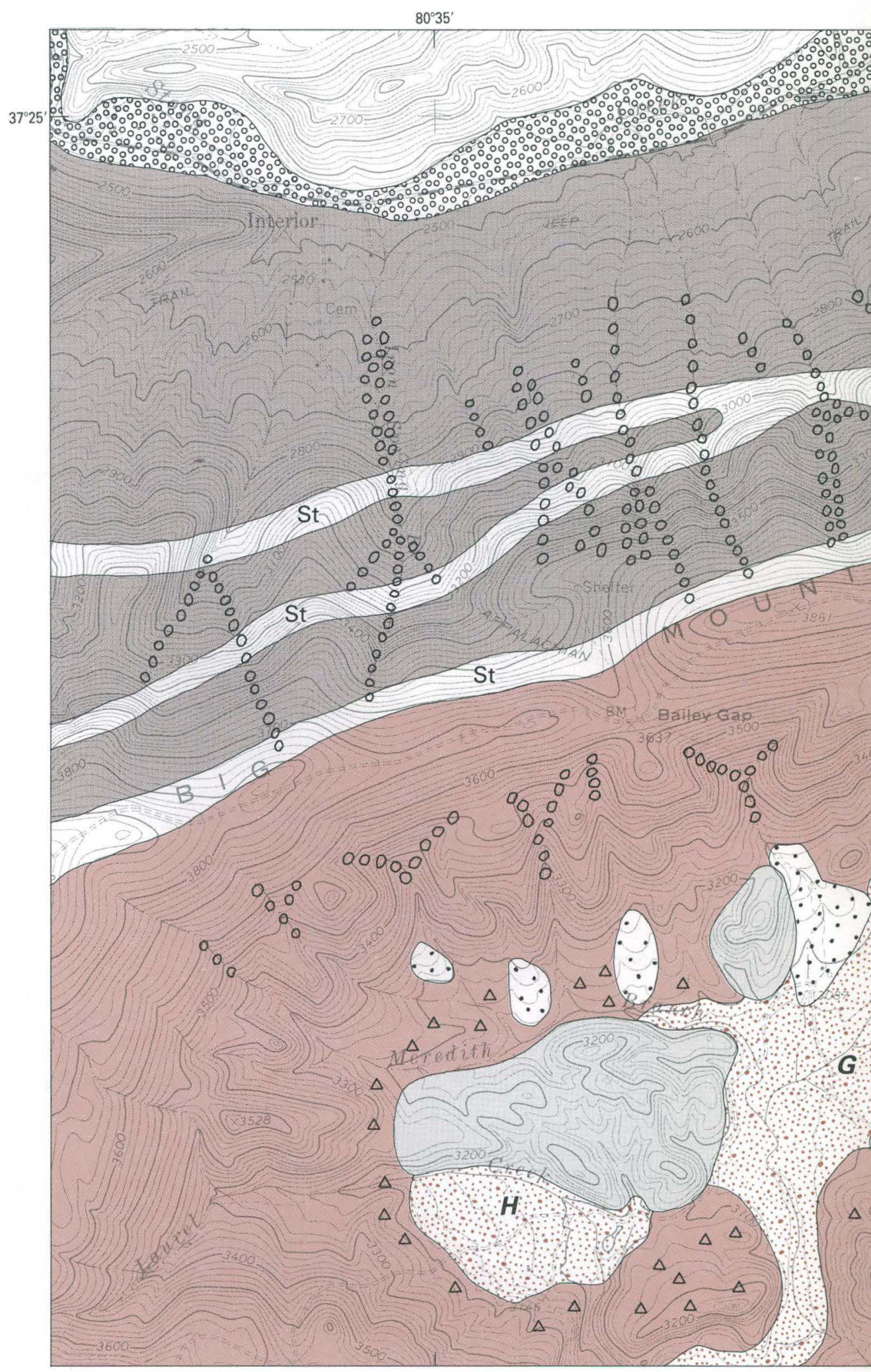




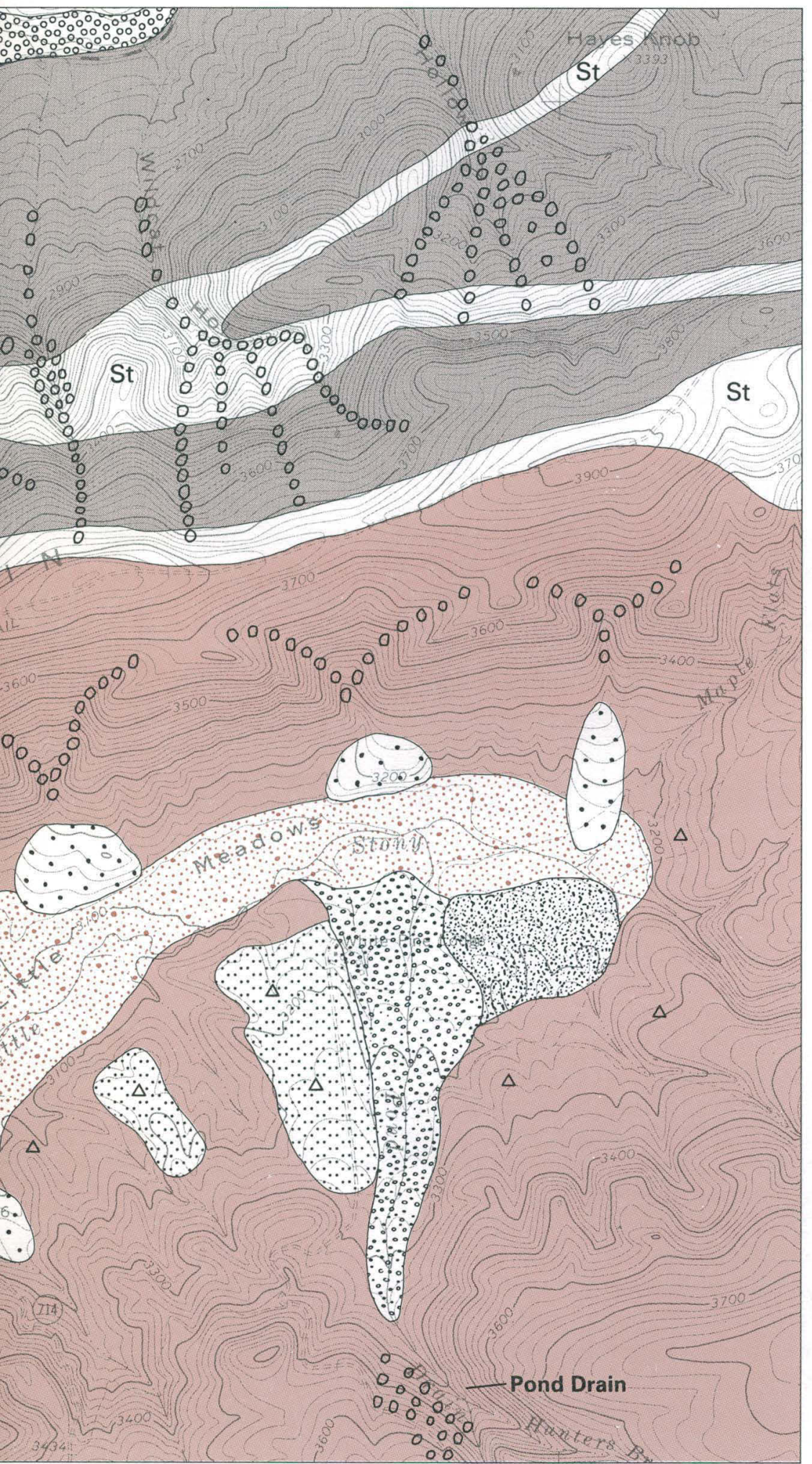

\section{EXPLANATION}

\section{Residual Regolith}

Shale residuum or bedrock

Sandstone residuum and slightly transported colluvium

\section{Transported Regolith Colluvium}

Younger, less weathered sandstone-rich colluvium

Older, more weathered sandstone-rich colluvium

\section{Transported Regolith Alluvium}

Fine-grained younger alluvium

Medium-grained younger alluvium

Coarse-grained younger alluvium

Older, more weathered alluvium

Probable old bedrock terrace without alluvial cover

\section{Other Symbols}

$\triangle \quad$ Areas having abundant chert fragments

Boulder streams and other dense accumulations of large boulders

St Tuscarora Quartzite (Silurian) 0

Figure 13.-Surficial geology of southern part of Interior quadrangle. Tuscarora Quartzite (St) outcrop belt is shown for outcrop slopes only. Map units are same as those for figure 3 . Letters $G-H$ indicate specific locations discussed in text. 


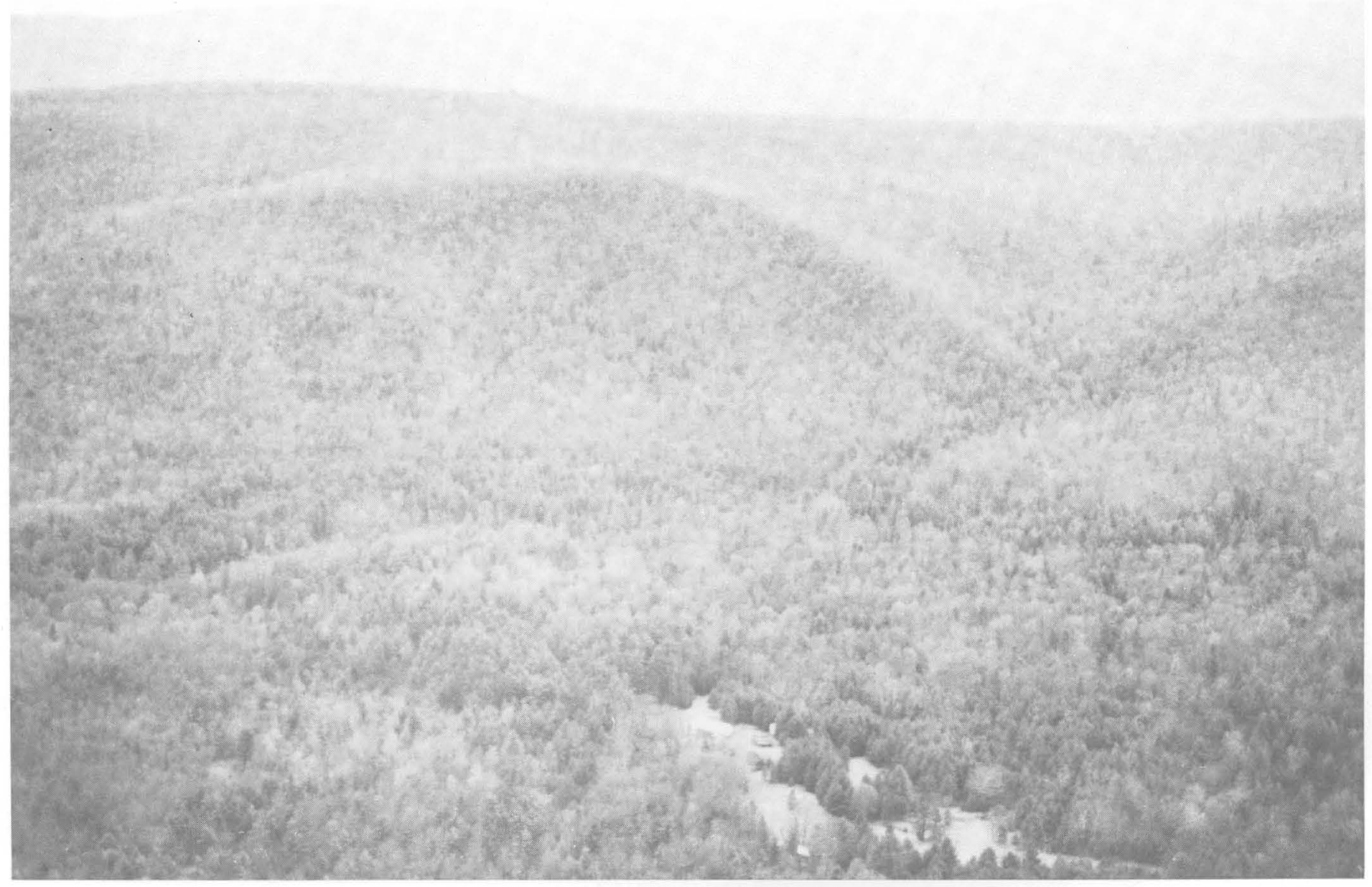

FIGURE 14.-South (dip) slope of Big Mountain, showing flatiron. White Pine Lodge visible in foreground.

caprocks is expanded. Previously, this role has been perceived mainly as one of shielding the immediately underlying less-resistant strata from the elements. Where the caprock produces large resistant boulders, however, these boulders extend the protection of the caprock by armoring the outcrops of the weaker strata far downslope from the caprock itself. These boulders appear to play an especially important role at the base of the mountain flank, where they may act in a manner similar to riprap to inhibit undermining of the mountain slope by laterally eroding streams.

The origin of Mountain Lake has engaged the attention of many previous investigators. This lake lies near the crest of the breached Mountain Lake anticline, its long axis near the trend of the fold. It rests chiefly upon the Juniata and Martinsburg Formations, although the outlet overlies the Tuscarora Quartzite (fig. 2). Two basic methods of origin have been suggested for Mountain Lake. Rogers (1884), Sharp (1933), Hutchinson and Pickford (1932), Eckroade (1962), and Parker and others (1975) favored damming by scree, whereas Platt and
Shoup (1950) and Marland (1967) preferred solution. Dietrich (1957) suggested a combination of these two origins.

Solution appears to be an unlikely origin. As pointed out by Sharp (1933) and Parker and others (1975), because of the great thickness of the insoluble Martinsburg Formation, it seems impossible that solution of limestone underlying this formation could have any effect on the surface topography. The scree-damming hypothesis has been described most lucidly by Sharp (1933), who theorized that initially the depression occupied by Mountain Lake had been a normal stream valley occupied by a stream flowing northward, tributary to Little Stony Creek. As long slopes of Juniata and Martinsburg were exposed just south of the outlet notch cut in the Tuscarora Quartzite, great blocks of this sandstone crept downward over the shale slopes, gradually filling the valley bottom. Weathered particles and organic material then filled the interstices, thus making a water-tight dam impounding the lake. As evidence for this theory, he noted that the depth of the 


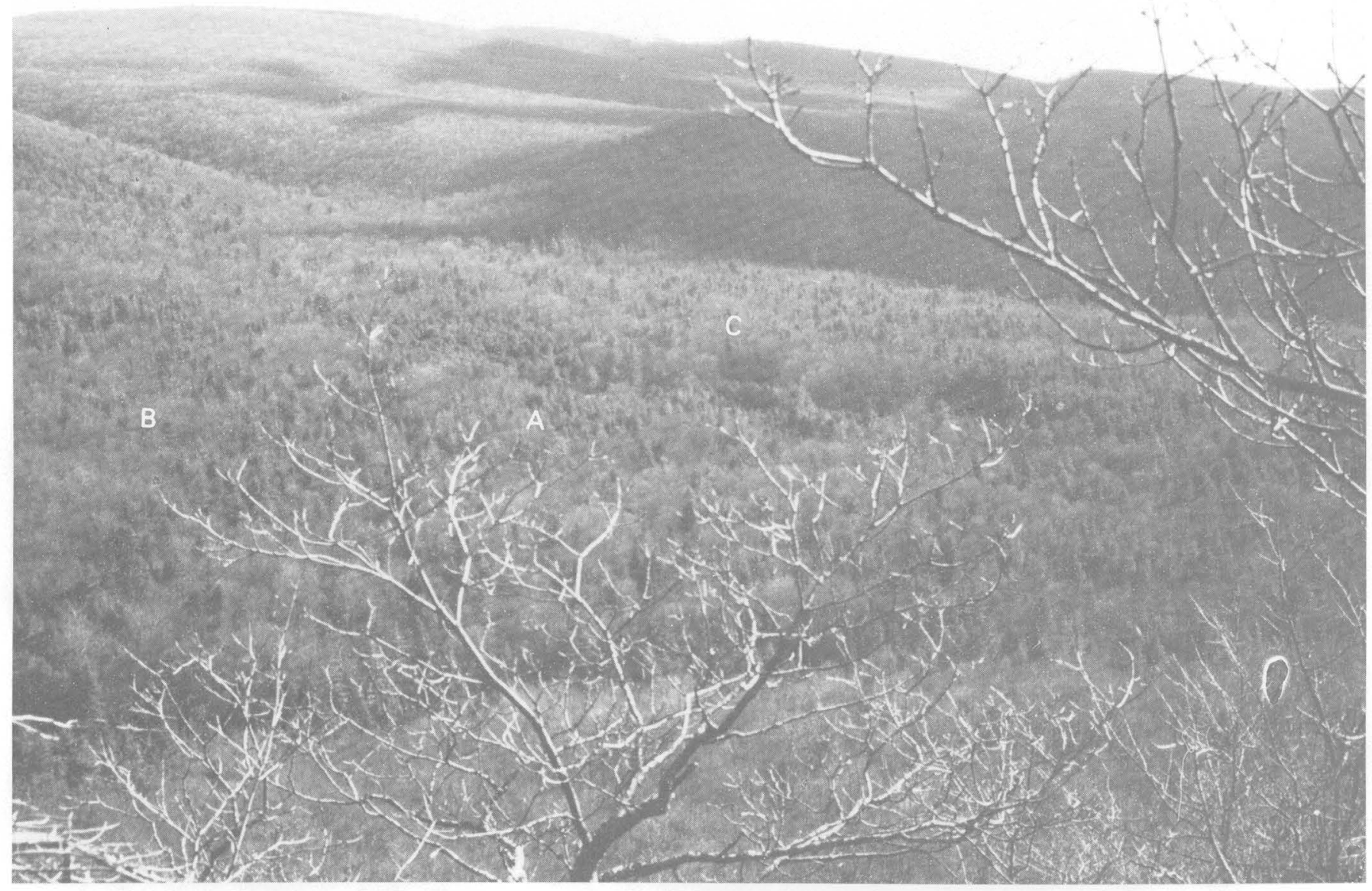

Figure 15.-Pond Drain fan and vicinity as viewed from near crest of Big Mountain. $A$, Surface of Pond Drain fan; $B$, Older surface east of Pond Drain fan; $C$, Older surface lacking an alluvial mantle, west of Pond Drain fan.

lake increases to the north, as should be expected if the depression had been occupied originally by a stream flowing to the north. In addition, the lake bottom near the outlet is composed of immense blocks of Tuscarora Quartzite. These blocks can be traced in "unbroken procession" from the lake bottom to their parent ledge of Tuscarora Quartzite about $100 \mathrm{~m}$ or so northeast of the lake (fig. 18). Sharp also observed a lack of large blocks west of the outlet, thus making it appear that the outlet stream had been crowded over to the west side of the notch in the Tuscarora by blocks creeping from the east.

Although the scree-damming theory appears quite plausible, two questions remain. First is the mechanism by which the blocks were transported. Although this area is noted for its seismic activity (for example, Bollinger and Wheeler, 1982), the slope below the parent ledge seems much too gentle for rockfall to have moved the blocks. More likely is Sharp's (1933) suggestion of creep, which may have been accelerated by gelifluction and other periglacial processes during full-glacial climatic conditions of the Pleistocene.

A second and more important question is why Mountain Lake is unique in the unglaciated Valley and Ridge province, where breached anticlines with Tuscarora Quartzite outcrops are common. Possibly, several circumstances combined to allow the formation of Mountain Lake: (1) the very gentle dips of the Mountain Lake anticline; (2) the relatively high local base level of the stream draining Mountain Lake; and (3) the relatively high altitude of the lake area. None of these conditions is uncommon in the Valley and Ridge province, but the combination of all three may very well be rare, if not unique. Most lakes formed by natural dams are soon drained by destruction of the dams. Thus, although creep of boulder scree into stream valleys probably has been common in this region, incipient dams have in most cases been rapidly eliminated. At Mountain Lake, 


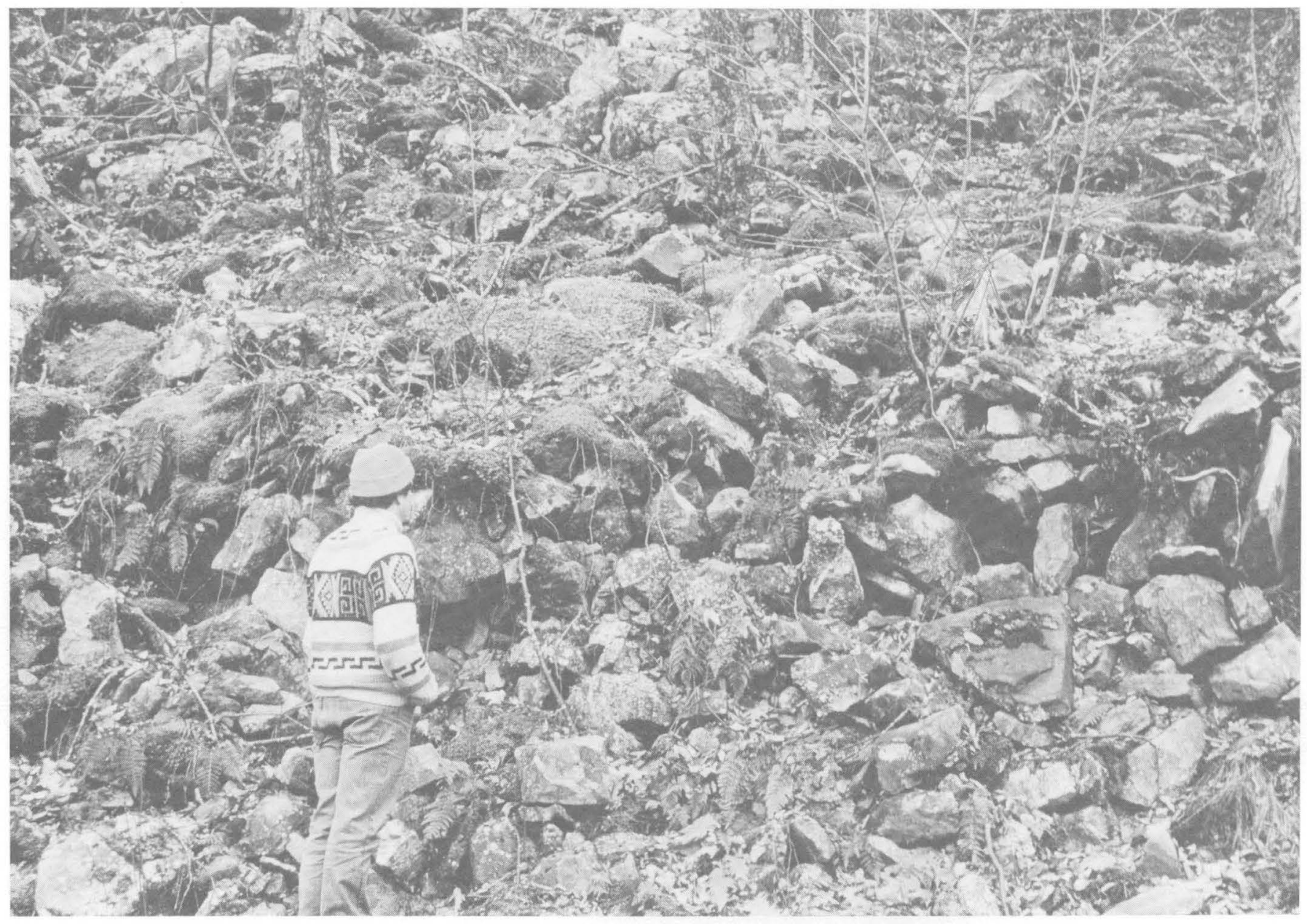

Figure 16.-Road cut through matrix-free boulder stream on north slope of Big Mountain at elevation of about $975 \mathrm{~m}$.

however, circumstances have made destruction of the dam exceedingly difficult. Because the huge Tuscarora blocks cannot be moved by any flow of water possible in such a small drainage basin, the only way to drain the lake would be for the outlet stream to cut down laterally to the dam. Pond Drain flows for more than $2 \mathrm{~km}$ over the gentle dip slopes of resistant sandstone (fig. 2), however, greatly hindering such incision. Downcutting is made still more difficult by the fact that the flood plain of Little Stony Creek (whose elevation is controlled by the sandstone units holding up the Cascades) constitutes the local base level of Pond Drain and lies only $236 \mathrm{~m}$ below the elevation of Mountain Lake itself. Hence, downcutting by Pond Drain has been minor, and there has been no opportunity for a headwarderoding nickpoint to provide the gradient below the dam necessary to cause local erosion vigorous enough to drain the lake. Another contributing factor may have been the relatively high altitude of Mountain Lake
(1,181 m), making block transport by Pleistocene periglacial processes more likely than at lower altitudes.

Figure 2 suggests that the most likely way for Mountain Lake to meet its end is not by breaching of its dam but by capture resulting from the headward erosion of Doe Creek. The headwaters reach of this stream is somewhat steeper than that of Pond Drain, and only the weak Martinsburg Formation stands in the way of the capture.

\section{SEDIMENTOLOGY OF COLLUVIUM}

\section{PREVIOUS WORK}

The problem of whether colluvium in the unglaciated Appalachians is the product chiefly of Pleistocene periglacial conditions or of modern hillslope processes has been addressed by many previous authors. Denny 


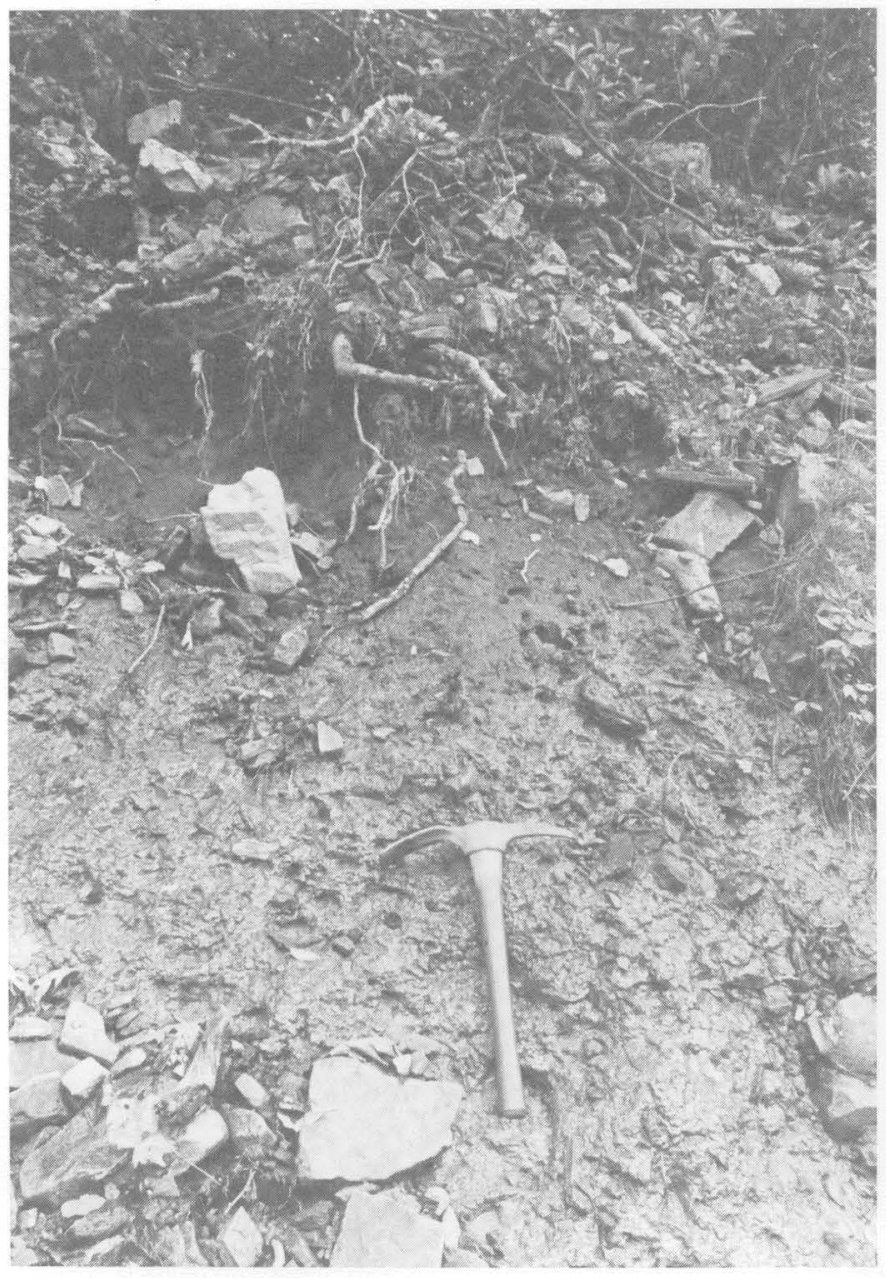

FIGURE 17.-Road cut through matrix-rich colluvium on north slope of Big Mountain at elevation of about $975 \mathrm{~m}$. Note stony mantle at ground surface above colluvium. Pick is $43 \mathrm{~cm}$ long.

(1951, 1956), Smith (1953), Michalek (1968), Potter and Moss (1968), Haselton (1973), Godfrey (1975), Hedges (1975), and Raymond (1977) concluded that slope deposits in this region are to a large extent relicts of Pleistocene cold periods. Other investigators, however, such as Gryta and Bartholomew (1983) and Kochel and Johnson (1984), implied that modern processes, particularly debris avalanches and flows set off by rare, catastrophic rainfalls, can account for most colluvium on mountain foot slopes.

The sedimentology of colluvium has received little attention, an exception being the study of roundstone diamicton by Pierce (1966). Hack and Goodlett (1960), Bogucki $(1970,1976)$, and Scott (1972) studied modern catastrophic-flood deposits, but only Williams and Guy (1973) investigated sedimentary properties of these deposits. Outside the Appalachians, by far the most widely investigated slope deposits have been those in arctic and alpine environments; many of these studies have been reviewed by Washburn (1980). Benedict (1976) has reviewed frost-creep and gelifluction studies. Relict periglacial deposits in the United Kingdom have been intensely studied by many authors with regard to their sedimentology.

A finding that may bear on the origin of colluvium is the existence of two or more ages of slope deposits, as indicated by degree of weathering, reported by Hadley and Goldsmith (1963), King (1964), Michalek (1968), Gryta and Bartholomew (1983), and Mills (1977). Although no dates have been obtained, Hadley and Goldsmith (1963) and Mills (1977) suggested that such multiple ages might reflect episodic deposition caused by Quaternary climatic cycles. Gryta and Bartholomew (1983) and Kochel and Johnson (1984), however, indicated that this age diversity may simply represent successive deposits from multiple catastrophic floods.

\section{DIFFERENTIATION OF COLLUVIUM ENVIRONMENT AND} AGE BY SEDIMENTOLOGIC AND WEATHERING CRITERIA

Sedimentologic data, including particle-size, clast roundness, clast fabric, and weathering indices, clearly discriminated colluvial deposits in five different environments. These environments are defined by topographic setting on hillslopes: Upper noses (slope angle $14^{\circ}$ or greater); lower noses (slope angle less than $14^{\circ}$ ); side slopes (and other steep slopes with thin colluvial mantles); moist, commonly north-facing, hollows within $500 \mathrm{~m}$ of the mountain crest (subsequently referred to as type $\mathrm{M}$ hollows); and other hollows (that is, dry, commonly south-facing hollows or hollows greater than $500 \mathrm{~m}$ from the crest, subsequently referred to as type D hollows).

These categories were devised after enough data were obtained to indicate differences among these settings. The lower-nose environment corresponds to the "older, more weathered sandstone-rich colluvium" map unit of figures 3 and 13, and the other four environments are included in the "younger, less-weathered sandstonerich colluvium" unit. At sites in each of these environments, measurements were made of fabric, clast roundness, particle-size distribution, color (Munsell color chart), and clast weathering. Sample sites, commonly located at road cuts, are shown on figure 2. For comparison, a few samples of alluvium were also included. Study was confined largely to outcrop slopes where sandstone-rich colluvium derived from the Rose Hill, Tuscarora, and Juniata units overlies the Martinsburg Formation. Here the mountain-flank topography is best developed, and the regolith is most easily recognized as transported as opposed to residual. The mean and standard deviation for each sedimentologic or weathering 


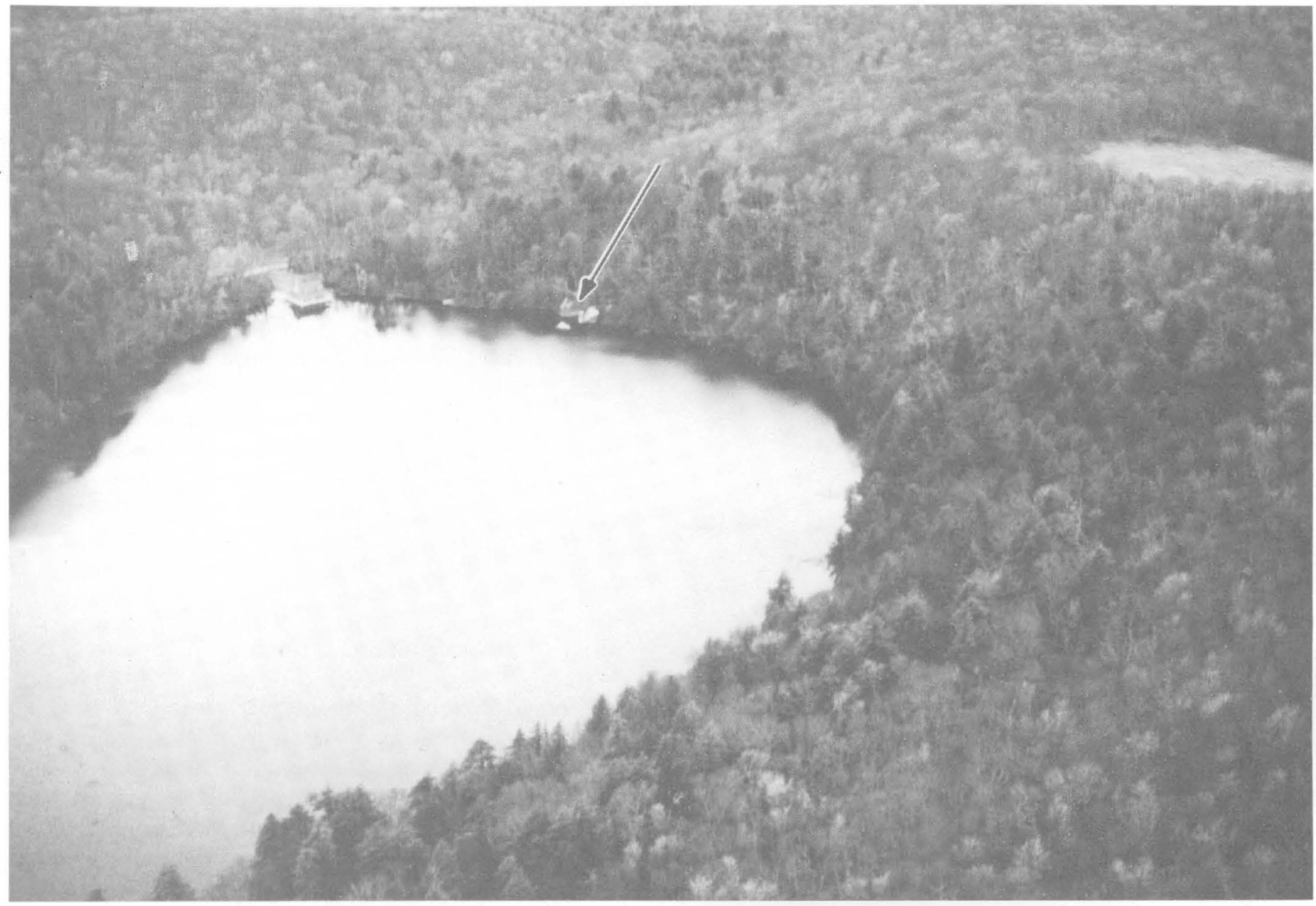

FIGURE 18.-North end of Mountain Lake. Arrow indicates large boulders that form the natural dam. Boulders were derived from Tuscarora Quartzite ledge a short distance upslope. Outlet is behind boathouse.

property in each environment is presented in table 2 ; in table 3 , the properties which differ at the $p \leq 0.05$ confidence level are shown for each pair of colluvium environments. Each property is discussed in detail below.

\section{PARTICLE-SIZE ANALYSIS}

The percent sand, silt, and clay of 67 samples of colluvium matrix are shown on a ternary diagram (fig. 19) as mean values and range envelopes for each environment. The mean and standard deviation of the percent clay (in the less-than-2-mm fraction) is presented in table 2, which shows that alluvium has the lowest percent clay (13 percent). Colluvium of hollows and side slopes has mean clay values ranging from 17 to 23 percent. Sites on upper noses have slightly higher clay values ( 29 percent), but the only percentage that is markedly different (43 percent) belongs to the lowernose environment. The lower-nose value is significantly different from that of the other four environments; the only other significant difference in percent clay is between upper noses and type $\mathrm{M}$ hollows (table 3 ).

A total of twenty-two $50-\mathrm{kg}$ samples containing clasts $\leq 256 \mathrm{~mm}$ were sieved in the field. The results are presented in figure 20 as average cumulative sizedistribution curves for each colluvial environment; the curve for a single sample of alluvium is presented for comparison. The results are roughly similar to those found for the fine fraction. Curves were also plotted for individual field-sieve samples, and the graphic mean $\left(M_{\mathrm{Z}}\right)$ and inclusive graphic standard deviation $\left(\sigma_{\mathrm{I}}\right)$ (Folk and Ward, 1957) computed for each. The means and standard deviations of these statistics for each environment are shown in table 2 . Table 3 shows that with regard to $M_{z}$, colluvium from lower noses is significantly different from colluvium in hollows, but not from upper noses or side slopes. Upper noses are significantly different only from type $\mathrm{D}$ hollows and side slopes. With regard to $\sigma_{I}$, colluvium from lower noses is significantly different from that from hollows. The 
inconsistent results of the significance tests probably arise from the small number of samples; a greater number almost certainly would increase the number of significant differences.

Individual field-sieve results are presented in figure 21, a ternary diagram showing percent gravel, sand, and silt+clay. Presentation in this fashion allows a comparison with seven samples of "roundstone diamicton sieved" by Pierce (1966), who apparently used a similar upper-clast-size limit. (His largest sieve was 128 $\mathrm{mm}$.) Note that Pierce's samples generally have lower silt+clay and higher gravel contents than the lowernose samples in this study. A $t$-test shows that the percent silt+clay differs significantly between the two groups of samples.

Many particle-size analyses have been done on periglacial slope deposits (for example, Benedict, 1970; Mottershead, 1976), and even more have been reported for debris flows (for example, Bull, 1962, 1964; Landim and Frakes, 1968; Pierson, 1980). Both types of sediment, however, show such wide variation in particlesize characteristics that this property is of little value in distinguishing them. Hence, particle-size distribution provides no clues as to the origin of the colluvium. A comparison with published data did produce one interesting result, however; the $\sigma_{I}$ values, particularly for the nose sites, are higher than any reported for either periglacial or debris-flow deposits.

\section{CLAST ROUNDNESS}

Table 3 shows clear differences in pebble roundness between environments. Studies of pebble rounding in streams generally have shown that mean roundness increases as a function of transport distance (Mills, 1979), suggesting that the observed roundness differences may simply reflect the fact that the deposits have been transported for different distances. In order to control for this factor, mean roundness values in figure 22 have been plotted as a function of distance from the mountain crest (which serves as distance of transport). For comparison, 17 mean roundness values of pebble samples taken from the beds of modern streams in the study area and vicinity have been plotted; the solid line is the regression equation calculated for the eight samples from Doe Creek. Note that roundness increases downstream more rapidly and consistently in Doe Creek than in the other streams, probably because conditions are more favorable for downstream rounding. First, Doe Creek leaves the outcrop of sandstones that supply its clasts much farther upstream than do other streams (fig. 2), flowing for most of its length over shale or limestone. Therefore, there is less opportunity for fresh, angular clasts to be added to the stream load.
TABLE 2.-Sedimentary characteristics, or values, of colluvium from five environments defined in the study area [Alluvium shown for comparison; n.a., not applicable]

\begin{tabular}{|c|c|c|c|c|c|c|}
\hline \multirow[b]{2}{*}{$\begin{array}{l}\text { Sedimentary } \\
\text { property }\end{array}$} & \multicolumn{6}{|c|}{ Environment } \\
\hline & $\begin{array}{l}\text { Upper } \\
\text { noses }\end{array}$ & $\begin{array}{l}\text { Lower } \\
\text { noses }\end{array}$ & $\begin{array}{c}\text { Side } \\
\text { slopes }\end{array}$ & $\begin{array}{l}\text { Type M } \\
\text { hollows }\end{array}$ & $\begin{array}{l}\text { Type D } \\
\text { hollows }\end{array}$ & Alluviun \\
\hline \multicolumn{7}{|c|}{ Percent clay } \\
\hline Mean ........... & 29 & 43 & 23 & 17 & 22 & 13 \\
\hline Standard deviation .. & 12 & 14 & 10 & 6 & 6 & 6 \\
\hline Number of samples.. & 9 & 16 & 14 & 7 & 15 & 6 \\
\hline \multicolumn{7}{|c|}{$\begin{array}{l}\text { Graphic mean of field-sieve samples }(\phi) \\
\end{array}$} \\
\hline Mean .......... & 1.1 & 3.4 & 0.9 & -0.5 & -2.1 & -4.0 \\
\hline Standard deviation - - & 0.5 & 1.8 & 1.3 & 1.7 & 1.5 & n.a. \\
\hline Number of samples- - & 3 & 6 & 4 & 4 & 4 & 1 \\
\hline \multicolumn{7}{|c|}{ Inclusive graphic standard deviation of field-sieve samples $(\phi)$} \\
\hline Mean ........... & 7.3 & 7.5 & 6.6 & 5.5 & 5.5 & 3.5 \\
\hline Standard deviation - - & 1.4 & .7 & .9 & .4 & .7 & n.a. \\
\hline Number of samples- - & 3 & 6 & 4 & 4 & 4 & 1 \\
\hline
\end{tabular}

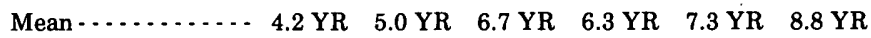

$\begin{array}{lllllll}\text { Standard deviation-- } & 1.2 \mathrm{YR} & 2.3 \mathrm{YR} & 1.8 \mathrm{YR} & 1.3 \mathrm{YR} & 1.5 \mathrm{YR} & 1.4 \mathrm{YR}\end{array}$

\begin{tabular}{llccccc} 
Number of samples - & 8 & 16 & 14 & 7 & 15 & 6 \\
\hline \multicolumn{10}{c}{ Chroma $^{1}$}
\end{tabular}

\begin{tabular}{lrrrrrr}
\hline Mean ............ & 4.8 & 6.7 & 4.4 & 4.0 & 4.5 & 4.8 \\
Standard deviation - . & 1.0 & 1.0 & 1.3 & 0.0 & 1.3 & 2.2
\end{tabular}

\begin{tabular}{lllllll} 
Standard deviation - - & 1.0 & 1.0 & 1.3 & 0.0 & 1.3 & 2.2 \\
Number of samples.- & 8 & 16 & 14 & 7 & 15 & 6 \\
\hline
\end{tabular}

\begin{tabular}{|c|c|c|c|c|c|c|}
\hline \multicolumn{7}{|c|}{ Percent weathered clasts } \\
\hline Mean...$\ldots \ldots \ldots$ & 25 & 57 & 4 & 5 & 4 & 2 \\
\hline Standard deviation - - & 8 & 17 & 5 & 6 & 7 & n.a. \\
\hline Number of samples.- & 8 & 13 & 2 & 3 & 14 & 1 \\
\hline \multicolumn{7}{|c|}{ Median surface clast size $(\phi)$} \\
\hline Mean $\ldots . . . . . . .$. & -5.8 & $<-3.0$ & -4.4 & -9.3 & -8.8 & -7.8 \\
\hline Standard deviation - - & .3 & - & 1.7 & .5 & .8 & .7 \\
\hline Number of samples.. & 7 & 4 & 8 & 4 & 10 & 8 \\
\hline \multicolumn{7}{|c|}{ Mean sample roundness } \\
\hline Mean....... & 2.20 & 3.36 & 1.90 & 2.36 & 2.54 & 3.53 \\
\hline Standard deviation - - & .22 & .34 & .08 & .11 & .38 & .94 \\
\hline Number of samples.- & 8 & 8 & 2 & 2 & 10 & 16 \\
\hline \multicolumn{7}{|c|}{ Fabric strength $\left(s_{1}\right)$} \\
\hline Mean..... & 0.592 & 0.499 & 0.630 & 0.725 & 0.546 & n.a. \\
\hline Standard deviation - - & .071 & .066 & .097 & .046 & .093 & n.a. \\
\hline Number of samples. - & 7 & 10 & 5 & 8 & 10 & n.a. \\
\hline
\end{tabular}

${ }^{1}$ Munsell Color (1975).

TABLE 3.-Significant differences between colluvium in different environments

The presence of a particular symbol for a pair of environments indicates that the two environments differ significantly $(p<0.05)$ with respect to that property, as determined by
a Student's $t$-test. Symbols are as follows: PC, percent clay in less-than-2-mm fraction; $M$, graphic mean of field-sieve sample; $\sigma_{k}$, inclusive graphic standard deviation of field-sieve sample; H, hue; C, chroma (Munsell); $\mathrm{PW}$, percent weathered sandstone clasts in the B horizon; SC, median surface clast size; R, mean pebble roundness; $F$, fabric strength, as defined by $s_{1}$ value (table 2 )

\begin{tabular}{ccccc}
\hline & $\begin{array}{l}\text { Upper } \\
\text { noses }\end{array}$ & $\begin{array}{c}\text { Lower } \\
\text { noses }\end{array}$ & $\begin{array}{c}\text { Side } \\
\text { slopes }\end{array}$ & $\begin{array}{c}\text { Type M } \\
\text { hollows }\end{array}$ \\
\hline
\end{tabular}

Lower noses.... PC, C, PW,

SC, R, F.

Side slopes $\ldots . .$. H, PW $\quad$ PC, H, C

$\begin{array}{cccc}\text { Type M hollows -.- } & \text { PC, H, PW, } & \text { PW, R, F. } & \text { PC, M }, \sigma_{I},\end{array} \quad$ SC, R, F $\begin{array}{ll}\text { SC, F. } & \text { C, PW. } \\ & \text { R, F. }\end{array}$

Type D hollows … $\mathbf{M}_{\mathrm{z}}, \mathrm{H}, \mathrm{PW}, \quad \mathrm{PC}, \mathbf{M}_{\mathrm{z}}, \sigma_{1}, \quad \mathbf{M}_{\mathrm{z}}, \mathrm{SC} \quad \mathrm{F}$ SC. H, C, PW, $\mathrm{SC}, \mathrm{R}$. 


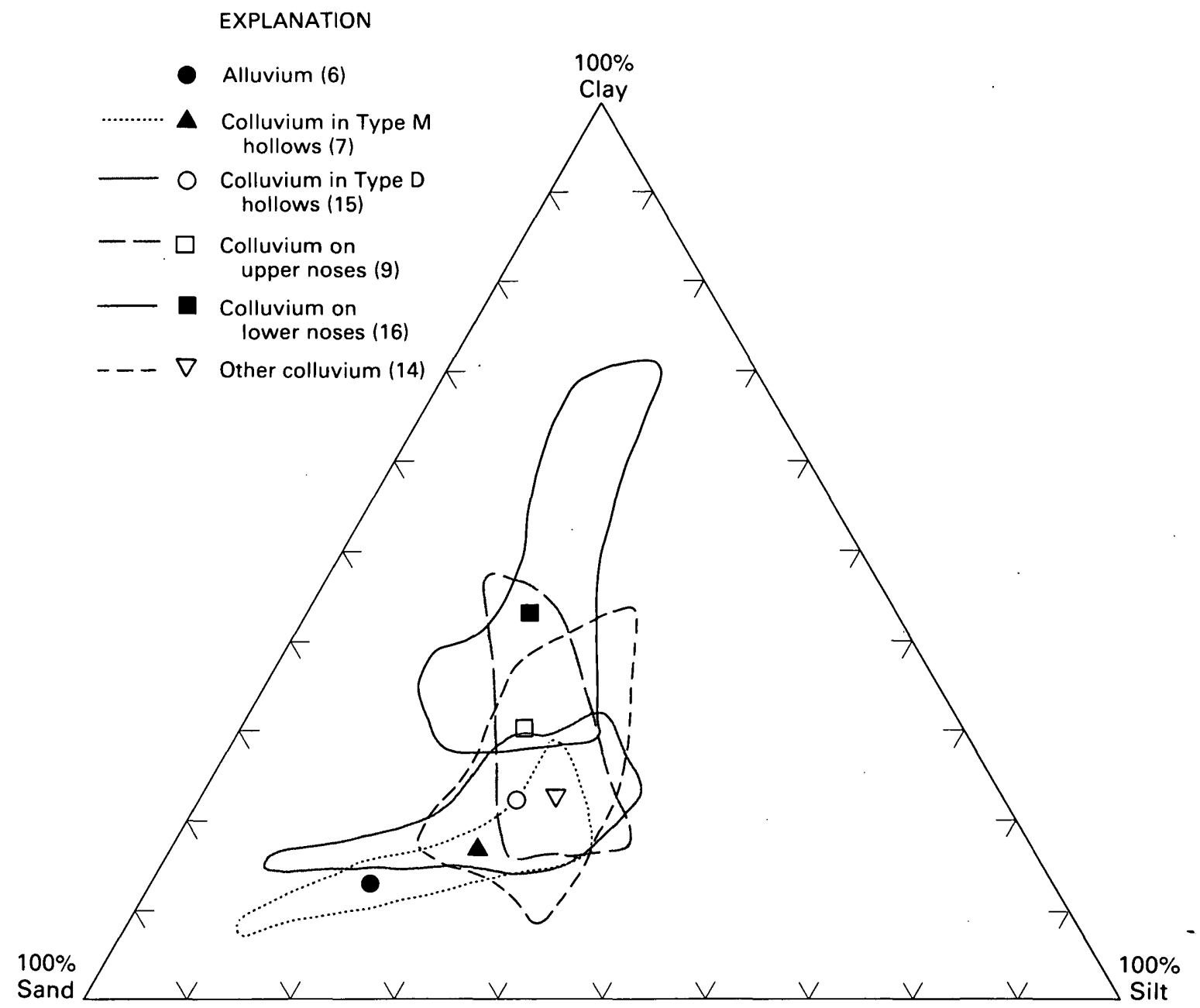

FIGURE 19.-Ternary diagram showing percent sand, silt, and clay (based on grade scale of Wentworth, 1922) of less-than-2 mm fraction of colluvial samples, in terms of mean and range for each environment. Number of samples in each environment is given in parentheses. Particle size was measured by sieve and hydrometer. Other colluvium is that on side and other steep slopes.

Additional sandstone clasts along its course are for the most part supplied only by major tributaries whose lengths are the same order of magnitude as that of Doe Creek itself; these clasts are already substantially rounded before they enter Doe Creek. Second, most of the sandstone clasts are composed of Tuscarora Quartzite or Rose Hill hematitic sandstone, tough lithologies that resist breaking. In contrast, other streams sampled (for example, Stony Creek and Little Stony Creek) flow over sandstone bedrock for a much greater percentage of their total length, so that fresh, angular clasts may be added along their courses. In addition, these streams also contain a high percentage of weaker sandstone clasts, especially those from the Rocky Gap Sandstone, which break easily and thus decrease roundness.

The regression line for Doe Creek is thus considered to be representative of the roundness-distance relation- ship in modern streams under favorable conditions. In fact, the slope of this line is comparable to slopes of regression equations calculated for several other studies of downstream rounding of pebbles (Mills, 1979). The 95-percent confidence interval was calculated for this regression, and the upper limit is shown as a dashed line on figure 22. The lower confidence limit has not been plotted, for I believe it less meaningful than the upper one, since there are many obvious factors that can decrease mean roundness for a given distance of transport. Two of these factors have been discussed; another is the erosion of angular clasts from colluvium along the sides of the stream. On the other hand, no factor that can increase the mean roundness above that normally seen in streams has yet been demonstrated. The data from previous studies of downstream rounding of pebbles show that there is no evidence of mean 
roundness increasing with distance faster in natural streams than in laboratory flumes (Mills, 1979). Hence, pebble samples having mean roundness values significantly above the Doe Creek regression lines are of much more interest than are those having values significantly below the line.

Figure 22 shows that most colluvial samples fall below the Doe Creek regression line; alluvial samples do the same. Figure 22 also shows, however, that the colluvial pebble samples tend to increase in mean roundness as a function of distance, a phenomenon observed for alluvial pebble samples. This finding allows a simple interpretation of the differences in mean roundness between colluvial samples for environments shown in tables 2 and 3 . The differences appear to be due simply to the fact that the distance of transport varies with environment, as suggested earlier. For comparison, seven pebble-roundness samples from roundstone diamicton measured by Pierce (1966) are plotted in figure 22. The roundness-distance relationship shown by these samples is comparable to that shown by samples from the lower-nose colluvial environment.

Aside from reflecting distance of transport, the roundness results probably give little information on genesis. Pebbles in debris flows show a much smaller downstream increase in roundness than to those in streams (Scott, 1971; Mills, 1978), which ideally might help to distinguish debris-flow from fluvial deposits. As discussed above, however, other factors can produce a low mean roundness. Pebbles in gelifluction deposits generally seem to be more angular than those in the present deposits (for example, Watson, 1969; Mottershead, 1976), but this difference may simply reflect greater Holocene weathering in the Virginia deposits. This finding raises the question of whether weathering can account for the observed roundness difference between environments. The lower-nose environment, for example, which has the most rounded clasts, also displays the most intense weathering. My impression, however, is that weathering is unlikely to be the chief cause of rounding. Although weathering can blunt sharp edges, for granular lithologies such as sandstone the outline of the clast's silhouette commonly becomes more ragged with greater weathering. Additional evidence against weathering as a major factor is provided by the similarity in roundness between the upper-nose and the type $M$ hollows (table 2), despite their difference in weathering environment. The transport distance of their deposits is similar, however.

One final point of interest concerns the two diamondshaped symbols in figure 22. These symbols represent samples taken from a foot slope in Clover Hollow (Newport quadrangle, near intersection of Routes 601 and 639 ; not shown) that conceivably could be an old

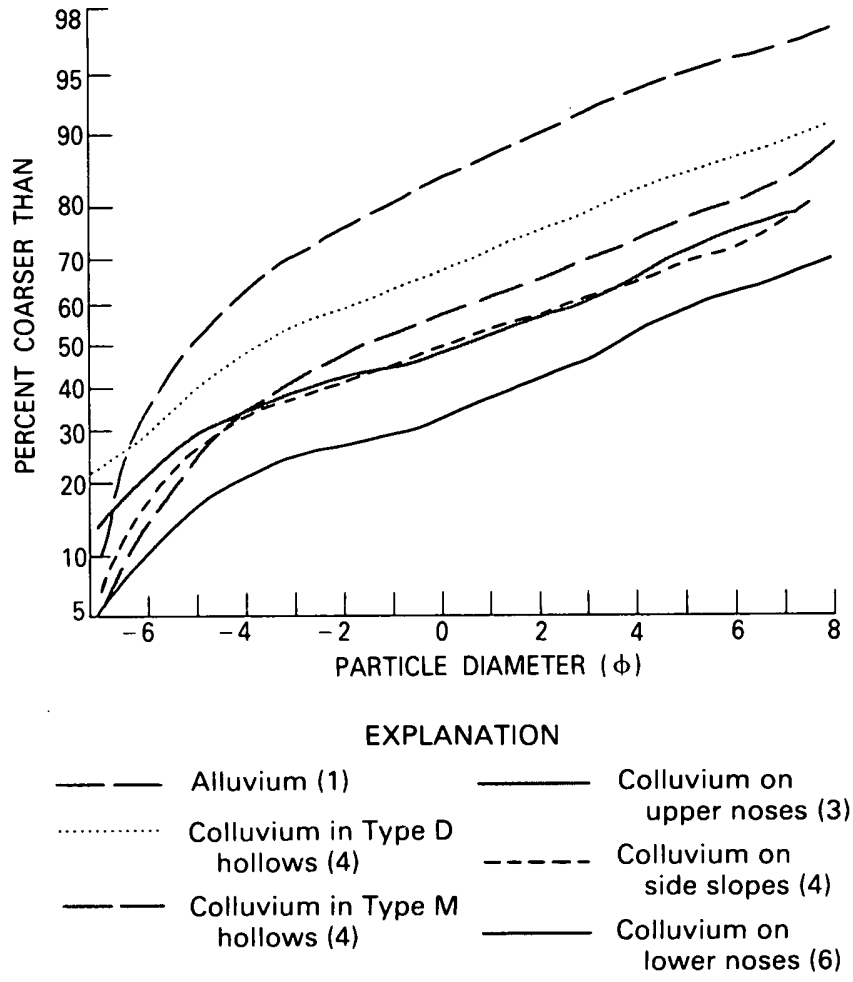

Figure 20.-Average cumulative particle-size curves for each colluvial environment based on field-sieving of samples containing clasts up to $256 \mathrm{~mm} \mathrm{(-8 \phi )}$ in diameter. Number of samples from each environment is given in parentheses. Samples weighed approximately $50 \mathrm{~kg}$ each and were sieved in the field by means of a Soiltest CL-320 Field Sieve Set (Rocker Sieve). The weight of particles in each size class was measured by means of a spring balance, and a split of particles less than 12.7 $\mathrm{mm}$ in size was taken and analyzed in the laboratory. The samples for field sieving were obtained by excavating, as nearly as possible, a cubic hole in the exposure.

terrace; the distance used on the plot assumes that the pebbles were carried from the most upstream point in the basin. Houser (1980) has suggested that this deposit was made by a former stream which flowed southwest from the Johns Creek syncline through Clover Hollow to the New River. Note that one sample does plot well above the confidence limit of the Doe Creek regression line, indeed suggesting a greater distance of transport than $3 \mathrm{~km}$.

\section{CLAST FABRIC}

Clast fabrics were measured at $\mathbf{4 0}$ sites in five different environments by digging a vertical exposure in the road cut and then determining the long-axis azimuth and dip of all suitable clasts within an area of about 0.5 $\mathrm{m}^{2}$, continuing to excavate within this area until 25 to 50 stones had been measured. No stones less than 20 


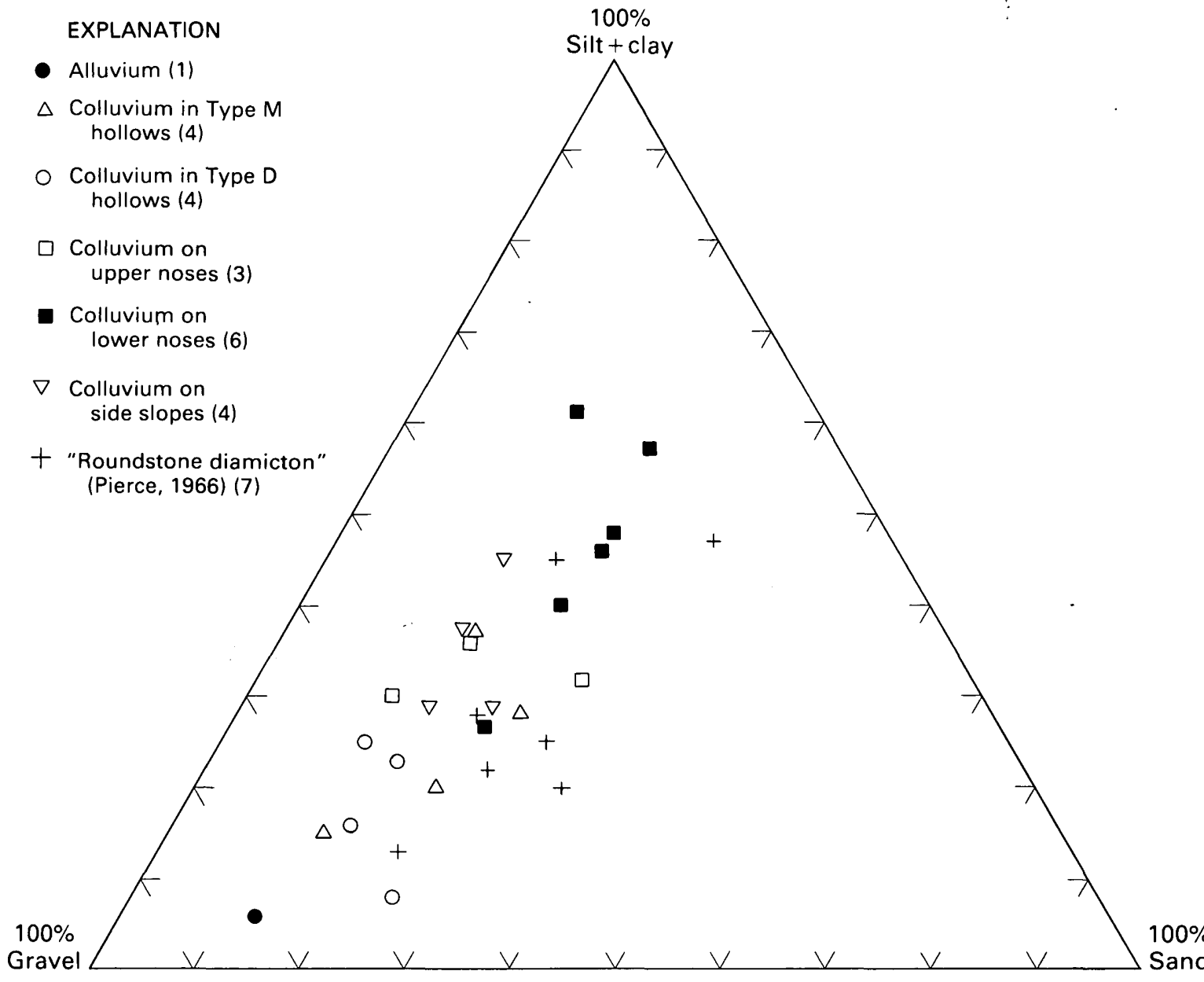

Figure 21.-Ternary diagram showing percent gravel $(>-1 \phi)$, sand $(-1 \phi$ to $4 \phi)$, and silt + clay $(>4 \phi)$ in each colluvial environment. Number of samples in each environment is given in parentheses.

mm long and only those stones with long axis-short axis ratios of $3: 2$ or greater were used.

Contoured Schmidt nets were plotted by computer for each site, but the results are here presented as composite nets (fig. 23). Except for the lower-nose net (fig. 23C), which suggests little preferred orientation, the patterns shown by the nets indicate a preferred alignment of long axes parallel to slope, with a preferred direction of dip downslope. As preferred dip angles tend to be lower than the slope angle, however, the fabrics generally have an upslope imbrication with respect to the surface. The consistency of stone orientation, subsequently referred to as fabric strength, obviously varies greatly between environments. The composite net for type $\mathrm{M}$ hollows (fig. $23 D$ ) has by far the strongest pattern, although the one for side slopes (fig. 23E) is also strong. No tendency for a transverse orientation was observed.
All 40 individual nets were examined in order to determine whether the composite nets were misleading, as might occur, for example, if strong parallel fabrics cancelled out strong transverse ones, thereby giving an erroneously weak composite fabric. In addition, the azimuth and dip of the largest eigenvalue $\left(V_{1}\right)$, which represents the axis of maximum clustering of the long axes, were plotted on a Schmidt net for each site possessing a significant $s_{1}$ value (fig. 24). Note that most sites show a preferred orientation in the downhill direction, with low dips. The exception seems to be the lower-nose environment where, although scatter is great, there appears to be a preference for the upslope direction. However, though significant, most of the individual fabrics in the lower-nose environment are weak, and as the composite net (fig. $23 C$ ) suggests, there is probably little preferred orientation in this environment. Pierce (1966) measured clast long axes at 


\section{EXPLANATION}

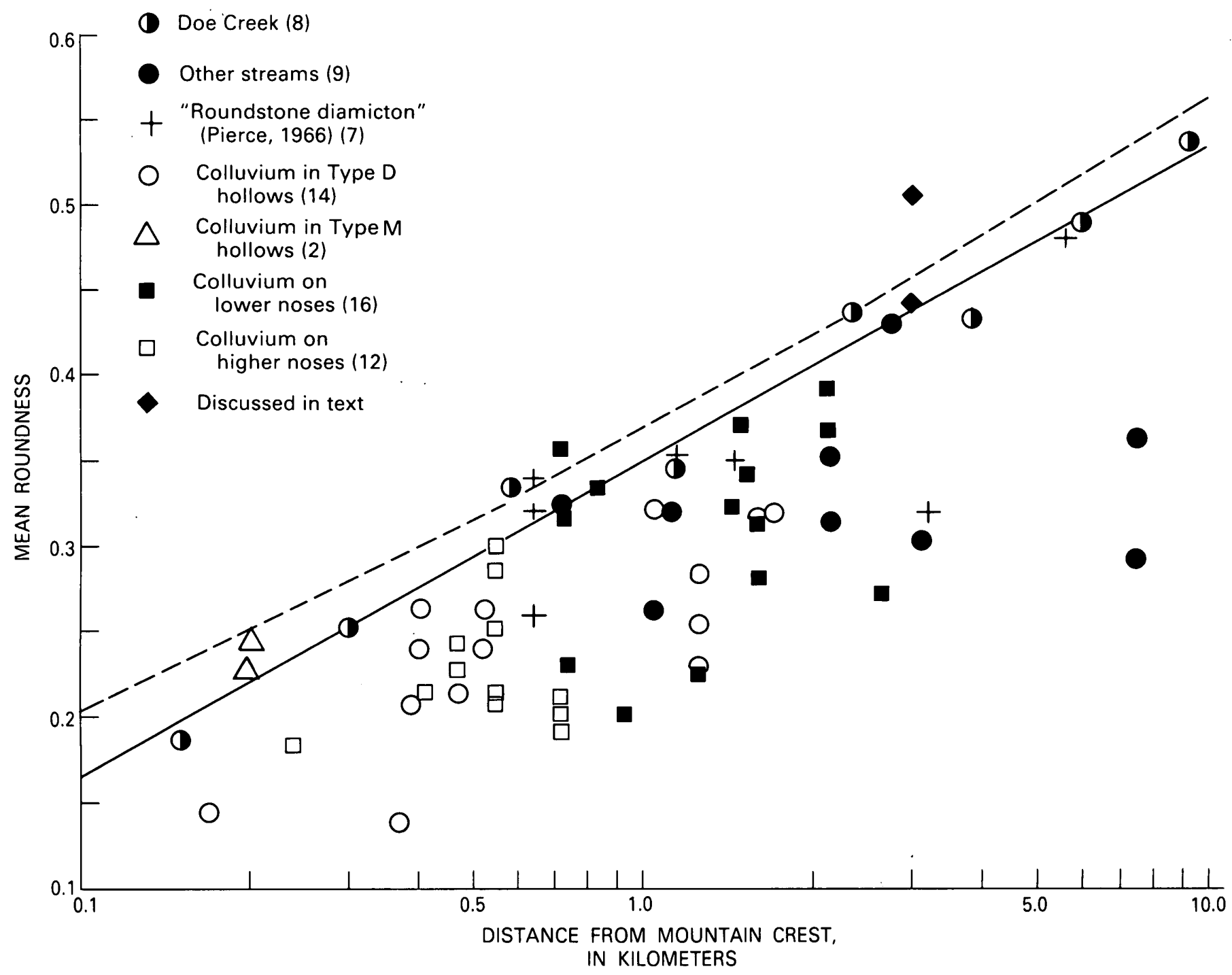

FIGURE 22.-Mean pebble roundness as a function of distance from mountain crest. Each roundness sample consisted of at least 25 sandstone pebbles. The numbers of samples here are greater than the numbers shown in table 2 because samples outside the immediate study area were included. The solid line is the regression equation based on the eight Doe Creek samples; the dashed line is the 95-percent upper confidence limit for this regression. The two side-slope samples had transport distances of less than $100 \mathrm{~m}$ and are not shown on the plot. The two samples represented by the diamond-shaped symbols are discussed in the text. Number of samples from each environment is given in parentheses. Only unweathered clasts 16 to $32 \mathrm{~mm}$ in intermediate diameter and consisting of resistant lithologies (chiefly Rose Hill and Tuscarora) were used. Roundness was measured by means of the visual comparison chart of Krumbein (1941).

five sites in roundstone diamicton and reported that the orientation was highly variable, being upslope at some sites but at right angles to the slope at others. This variability suggests a similarity to the lower-nose fabrics shown in figure 24.

Fabric-strength differences between environments were examined quantitatively by a comparison of $s_{1}$ values. The mean and standard deviation of the $s_{1}$ values for each environment are presented in table 2 , and the 40 values from individual samples are pre- sented in figure 25 in the form of a histogram. The histogram generally supports the trend displayed in the composite Schmidt nets (fig. 23), in that the sites in type $M$ hollows have by far the strongest fabrics, and the lower-nose sites obviously have the weakest. Table 3 shows that sites from type $M$ hollows are significantly different from all the other environments. Lower noses differ from all but the type D hollows. No other significant differences occur. Table 3 also shows that of all the sedimentary properties, the two hollow environ- 

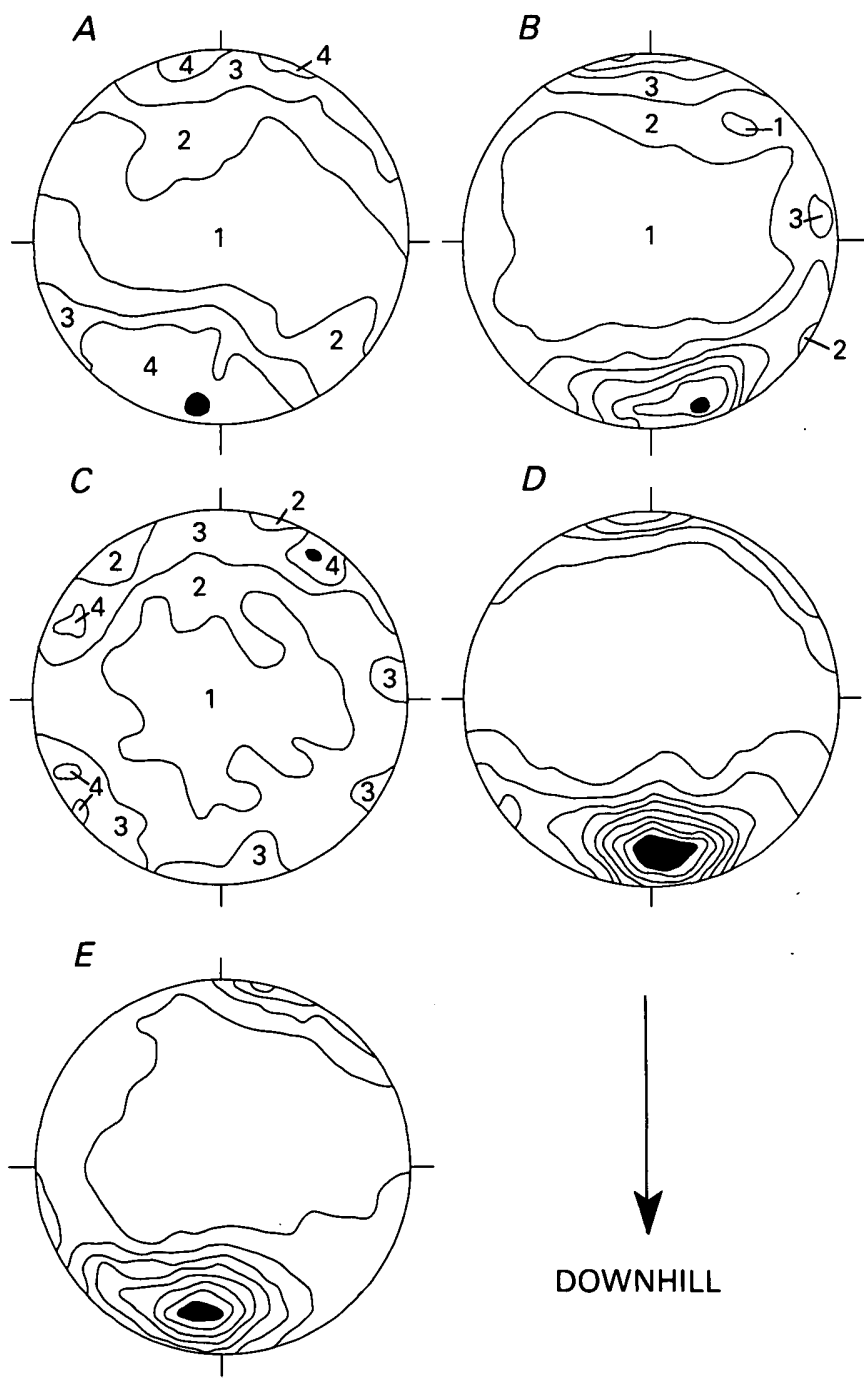

FIGURE 23.-Composite equal-area (Schmidt, lower hemisphere) nets for each colluvial environment. The downslope direction is toward the bottom. Contouring was done by the method of Kamb (1959) using a computer subroutine by Corbato (1965) at contour intervals of two standard deviations. Composite plots were made for each environment by rotating the stereographic nets of all samples from that environment so that the downslope direction of each was at the same position; then all the points were contoured as one net. The rationale for this procedure is analogous to summing signals on an oscilloscope, in that when viewed individually the Schmidt net for each site may show such a weak fabric that no trend is evident; if the nets have any common trend, however, then adding them together should result in the "noise" averaging out and the "signal" increasing in amplitude. The black areas represent the densest concentration of axes. On diagrams where intervals have been numbered, higher numbers represent denser concentrations of axes. $A$, Composite of 10 sites in type $\mathrm{D}$ hollows. $B$, Composite of seven sites on upper noses. $C$, Composite of 10 sites on lower noses. $D$, Composite of eight sites in type $\mathrm{M}$ hollows. $E$, Composite of five sites on side or other steep slopes. ments differ only with respect to fabric. This difference was so dramatic that it was considered a sufficient basis for distinguishing the two environments.

Clast fabric possibly can discriminate between gelifluction and debris-flow deposits. Fabric pattern is not very helpful because many mass-wasting deposits exhibit clasts with a preferred long-axis orientation parallel to slope and imbricated uphill (Benedict, 1976), as do the present colluvial deposits. Fabric strength, or the consistency of long-axis orientation, may be more useful, however. Many investigators have reported quite strong fabrics in gelifluction deposits (for example, Kirby, 1967; Mottershead, 1976; Brochu, 1978; Nelson, 1985), whereas debris-flow fabrics, though much less studied, commonly are relatively weak (Lindsay, 1968; Williams and Guy, 1973; Mills, 1984). This fabric difference probably results from the laminar flow of gelifluction and the turbulence of debris flows.

In the present study, the very strong fabrics of the deposits of the type $\mathbf{M}$ hollows are compatible with a gelifluction origin, particularly as these locations are north facing and high where Pleistocene climatic conditions would have been most rigorous. Other forms of laminar flow cannot be eliminated as the cause of the fabric strength, however. Creep, for example, probably accounts for the relatively strong fabrics shown by the side slopes (Mills, 1983), although this process probably does not account for the hollow deposits with their somewhat gentler slopes. The weakness of fabrics in the type D hollows appears to exclude gelifluction, an exclusion which seems reasonable since the south-facing hollows would have been warmer and dryer than other hollows during the Pleistocene glacial climates and hollows greater than $500 \mathrm{~m}$ from the crest are more likely to have been the sites of debris flows because of their greater drainage areas. Weak fabrics alone, however, cannot prove that these deposits are debris flows.

\section{WEATHERING INDICES}

In the absence of dates, relative-age techniques were used to order surficial deposits into "older" and "younger" categories. These techniques involve the measurement of weathering criteria believed to be a function of age (Birkeland, 1974). The criteria used in this study were the percent clay in the less-than-2-mm fraction (discussed earlier), the chroma and hue (Munsell color chart) of the B2 horizon, the surface medianclast size, the percent weathered sandstone clasts in the $B$ horizon, and the percent resistant versus nonresistant clasts. Results are shown in tables 2 and 3 .

Note that the hue of nose environments differs significantly from other environments (except that type $M$ hollows are not significantly different from lower noses) 
but that the nose environments are not significantly different from each other. This similarity between the two nose environments may exist because the red pigment supplied to the colluvium by the Rose Hill and Juniata Formation masks the differences in hue that otherwise would arise from differences in degree of weathering. Chroma, however, which is the strength of the color (or the departure from a neutral of the same lightness), does differ significantly between upper and lower noses, being stronger in the latter environment. Stronger chroma, like redder hue, probably indicates a greater degree of weathering. Mean chroma values were approximately the same in the other environments (table 2).

The median size of surface clasts was measured at 51 sites by laying a tape on the ground and measuring the intermediate diameter of the clast beneath each $50-\mathrm{cm}$ mark to the nearest half-phi interval until 50 clasts had been measured. Where no clasts were visible on the surface beneath a mark, a 10-cm rod was inserted into the duff, and the first clast encountered was dug out and measured. If no clast $8 \mathrm{~mm}$ or larger was encountered, a "less-than-8 mm" size was recorded for that location. The median size was then determined. This index is analogous to the "surface boulder frequency" index used in many studies of alpine glacier deposits (for example, Blackwelder, 1931; Burke and Birkeland, 1979). The rationale is that surface clasts decay with time, just as do subsurface clasts, so that older surfaces should have fewer and smaller clasts. On lower-nose sites, fewer than half the sampling points had clasts 8 $\mathrm{mm}$ or larger, so that no median value could be obtained. To allow statistical testing, however, a median of $-3 \phi(8 \mathrm{~mm})$ was assumed for these sites, as was a standard deviation of $0.8 \phi$ (the average of standard deviations in other environments). Tables 2 and 3 show that hollow environments have much coarser mantles than do other environments and that lower noses have somewhat finer mantles than do upper noses. Lower noses did not differ from side slopes, mainly because colluvium in the latter environment has a large content of shale chips.

Percent weathered sandstone clasts was measured by digging out 25 sandstone clasts approximately 20 to $40 \mathrm{~mm}$ in diameter and determining whether they could be broken apart by hand. Clasts that could be disaggregated into pieces granule size or smaller were classified as "weathered" and the percent weathered then computed. Hematite-cemented sandstone clasts were excluded, as they were rarely weathered. The bulk of the measured clasts was derived from the Juniata Formation, as most of those from the Rose Hill were hematitic, and pebble-size clasts of Tuscarora were relatively uncommon. The percent-weathered-clasts index is an

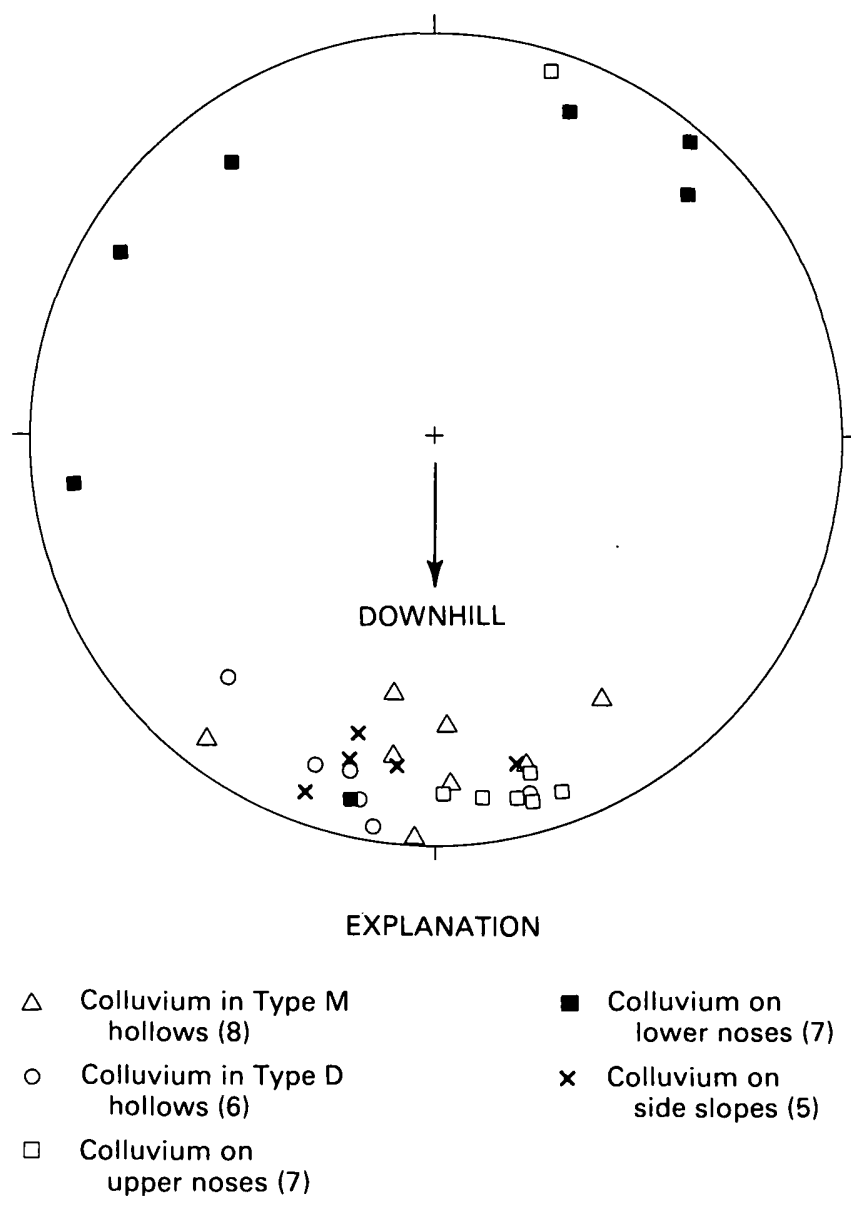

Figure 24.-Schmidt net showing the azimuth and dip of $V_{1}$ (the axis of maximum concentration) for each fabric sample having a significant $s_{1}$ value (from table 2). Each fabric has been rotated so that the downslope direction is toward the bottom. Statistical analysis of the fabric was by means of the eigenvalue method (Scheidegger, 1965; Mark, 1973). This method produces three eigenvalues $\epsilon_{1} \geq \epsilon_{2} \geq \epsilon_{3}$ and their associated mutually perpendicular eigenvectors $V_{1}, V_{2}$, and $V_{3} . V_{1}$ represents the axis of maximum concentration of the long axes. The quantities $s_{1}, s_{2}$, and $s_{3}$ are defined by $s_{\mathrm{i}}=\epsilon_{\mathrm{i}} / N$. A table by Anderson and Stephens (1971) allows the $s_{1}$ value to be tested to determine whether the $V_{1}$ value is significantly different from the value expected for a random sample of axes drawn from a uniform population.

accurate measure for discriminating between older and younger deposits (tables 2, 3). Colluvium in hollows and on side slopes shows few weathered clasts. Although only one count was made, alluvium appears to be similar in this respect. The colluvium on noses, however, has a substantial percent of weathered clasts, the lower noses showing on average more than twice as high a percent as upper noses (57 percent vs. 25 percent). This increase suggests an explanation for the fact that colluvium in the lower-nose environment is deficient in gravel-size clasts (fig. 21): So many clasts are weathered that inevitably clasts retained on the screens during 


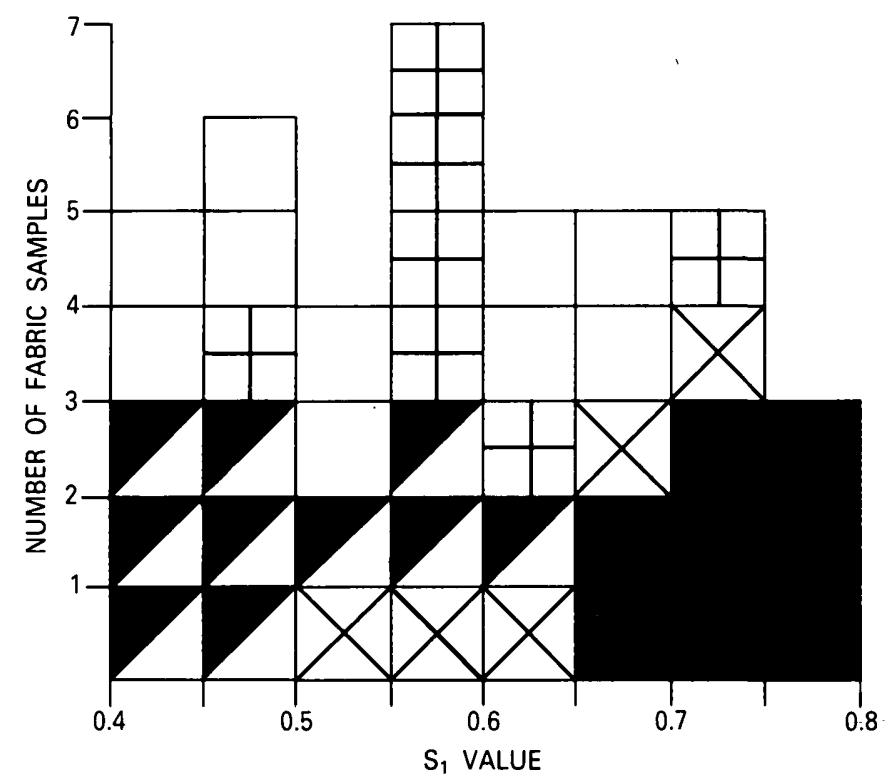

EXPLANATION

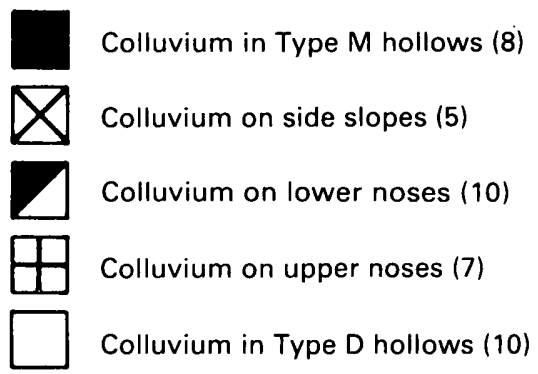

FIGURE 25.-The distribution of fabric strength for each environment, as indicated by the $s_{1}$ value, for each site.

field sieving are fewer and smaller than those occurring in other environments.

Pierce (1966) and Fiedler (1967) observed that older colluvial deposits have higher contents of the more resistant hematitic sandstone clasts than do younger deposits. The results of 21 lithology counts in uppernose, lower-nose, and hollow environments lend some support to the previous reports but also suggest that the inherent variability in abundance of hematitic sandstone clasts precludes the use of abundance as a weathering index. Some lower-nose sites were greatly enriched in hematitic clasts. One sample at site 401 (fig. 2), for example, had 73 percent hematitic clasts, whereas another sample $5 \mathrm{~m}$ away had only 50 percent. Both of these were higher than the highest percentage counted in upper-nose colluvium, but the mean percentage for upper noses (35 percent for six sites) was actually slightly higher than that for lower noses ( 31 percent for nine sites). Both means were higher than the mean percentage for hollows (24 percent for six sites). None of these differences was significant.

WEATHERING RINDS OF TUSCARORA QUARTZITE CLASTS

Sandstone weathering rinds proved too variable to use as a weathering index. These rinds, however, are very well developed and may have the potential for providing much information about the history of the colluvial deposits. I have, therefore, included a description of some representative rinds on Tuscarora Quartzite clasts, the lithology upon which rinds were best developed.

The most interesting characteristic of the rinds is that commonly there are two or even three concentric rinds of different colors on the same clast. Peltier (1949, p. 33) described such rinds on clasts composed of "medium-grained, white sandstone" (perhaps comparable to Tuscarora Quartzite) on Pleistocene terraces of the Susquehanna River. He reported that in Wisconsinan deposits, clasts commonly have a single, buffcolored rind about $3 \mathrm{~mm}$ thick. In older (Illinoian?) deposits, clasts commonly have an outer yellowishbrown rind about $3 \mathrm{~mm}$ thick underlain by a darkbrown or reddish-brown layer about 6 to $13 \mathrm{~mm}$ thick. In some older pebbles, he observed up to four "zones of weathering," including the interior of the pebble. $\mathrm{He}$ thought that the successive zones could be taken as a record of the weathering history of the pebble.

Clasts with rinds analogous to those described by Peltier occurred in colluvial deposits in the present study area. Rinds at many sites are somewhat more variable than Peltier suggested, however. A representative selection of rinds is presented schematically in figure 26. Clasts showed one to three rinds in practically every possible combination of observed colors. Variability was so great that only a few generalizations are possible. First, deeply buried clasts (generally greater than $1 \mathrm{~m}$ deep) do not have rinds as well developed as those at shallower depths. Second, clasts on steep, upper slopes or on mountain peaks and clasts in hollows or valley bottoms have less well developed rinds and are less likely to have multiple rinds than clasts on noses. At site 32 at $1,235 \mathrm{~m}$ on the south slope of Bean Field Mountain (fig. 2), for example, half of the clasts in the upper $30 \mathrm{~cm}$ had virtually no rinds, and the other half had vaguely defined light-yellow rinds (fig. 26B). At site 35 on peak 3040 near Rocky Mountain (Interior quadrangle; not shown in fig. 2), clasts had white rinds 1 to $2 \mathrm{~mm}$ thick and a gray interior (fig. $26 \mathrm{C}$ ), and a few had white rinds underneath brown ones and a light yellow interior (fig. 26E). The hollow at site $6 \mathrm{E}$ (fig. 2) showed rinds similar to those in figure $26 A$, about $1 \mathrm{~mm}$ thick. Multiple rinds were common at a few sites. Peb- 
bles on a terrace of Little Stony Creek (site 5B, fig. 2), for example, showed 2-mm-thick white outer rinds underlain by 2 -mm-thick dark-brown inner rinds (fig. 26D).

Rinds were best developed and most likely to be multiple on colluvium-capped noses; even within a single soil horizon at an individual site rinds varied greatly. Descriptions of clasts sampled in a soil pit dug at site $6 \mathrm{D}$ (fig. 2) illustrate this variety. Of 15 Tuscarora clasts taken from 0 to $30 \mathrm{~cm}$ below the surface, 7 showed the pattern of figure $26 F$, with the purple rinds ranging in thickness from 0.5 to $1 \mathrm{~mm}$ thick. Of the remaining clasts, six showed the pattern depicted in figure $26 G$, the yellow rind usually being 2 to $3 \mathrm{~mm}$ thick but $8 \mathrm{~mm}$ thick in one case. The remaining two clasts showed double rinds as shown in figure $26 \mathrm{H}$. In both clasts the outer rind was $0.5 \mathrm{~mm}$ thick; the inner rind was $2 \mathrm{~mm}$ thick in one case, $4 \mathrm{~mm}$ thick in the other.

Of 15 clasts taken from 60 to $90 \mathrm{~cm}$ depth, 9 showed the pattern depicted in figure $26 G$, although at this level the interior was commonly pink in color. The yellow rind ranged from 2 to $5 \mathrm{~mm}$ in thickness. Two clasts showed the pattern of figure $26 I$, and in one of these the red inner rind was truncated by the outer band. Three clasts showed the pattern of figure $26 \mathrm{~F}$, except that the outer rind was a pale purple and was 10 mm thick in one case. One clast was half yellow and half brick red, the boundary cutting through the clast. Note that despite the variety, the two levels did differ. In the upper $30 \mathrm{~cm}, 9$ of 15 clasts had purple outer zones, whereas in the lower $30 \mathrm{~cm}$ only 3 did, and even those were pale, perhaps suggesting that they were in the process of disappearing. Figures $26 J, 26 K$, and $26 L$ show additional combinations seen on another colluvium-capped nose (site 25A, fig. 2).

Finally, there is a suggestion that the multiple rinds of at least some clasts formed sequentially rather than simultaneously, for an outer rind truncates an inner one, indicating that the inner rind was formed first, the clast then broken, and the second rind subsequently formed. Different conditions may foster formation of different-colored rinds, so that multiple rinds may reflect a changing clast environment. Such change might be caused by climatic change or by movement of the clast into a different soil horizon by means of tree fall or other disruption of the soil profile.

\section{VERTICAL VARIATION IN WEATHERING CHARACTERISTICS}

Table 4 compares the soil A1 and B2 horizons at three sites on colluvium-capped noses with respect to hue, percent clay, and percent weathered clasts. The B2 horizons are redder, have a higher percentage of clay, and have a much higher percentage of weathered clasts than the A1 horizons. The latter difference probably
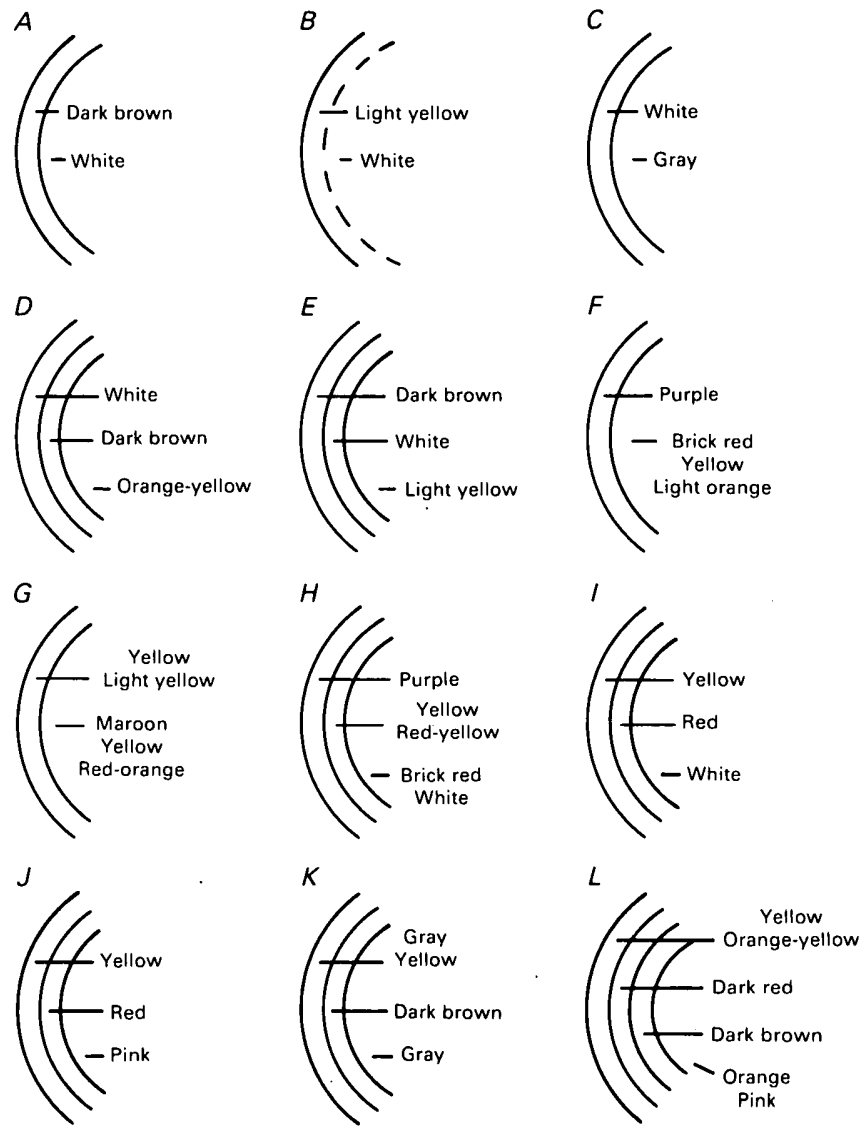

Figure 26.-Schematic diagram of colors and combinations of weathering rinds observed on sandstone clasts. Samples $A-L$ are discussed in the text.

TABLE 4.-Weathering differences between A1 and B2 soil horizons on colluvium-capped noses [Site locations are shown on figure 2]

\begin{tabular}{|c|c|c|c|}
\hline Horizon & Hue $^{1}$ & $\begin{array}{l}\text { Percent weathered } \\
\text { sandstone clasts }\end{array}$ & Percent clay \\
\hline \multicolumn{4}{|c|}{ Site 6 D } \\
\hline A1 $\ldots \ldots$ & $10.0 \mathrm{YR}$ & 20 & 17 \\
\hline $\mathrm{B} 2 \ldots$ & $5.0 \mathrm{YR}$ & 65 & 24 \\
\hline \multicolumn{4}{|c|}{ Site $25 \mathrm{~A}$} \\
\hline A1 $\ldots \ldots \ldots \ldots$ & $7.5 \mathrm{YR}$ & 0 & 16 \\
\hline B2 . . . & 5.0 YR & 24 & 39 \\
\hline \multicolumn{4}{|c|}{ Site 65} \\
\hline 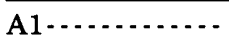 & $7.5 \mathrm{YR}$ & 8 & 21 \\
\hline B2 $\ldots$ & $2.5 \mathrm{YR}$ & 64 & 48 \\
\hline
\end{tabular}

reflects the complete destruction of even the "ghosts" of weathered clasts in the A1 horizon by bioturbation and other mechanical disturbances, so that only the most resistant clasts remain. This interpretation is supported by the fact that clasts generally are smaller and fewer in the upper horizon, as illustrated by figure 27 which is a drawing made from a photograph of the 


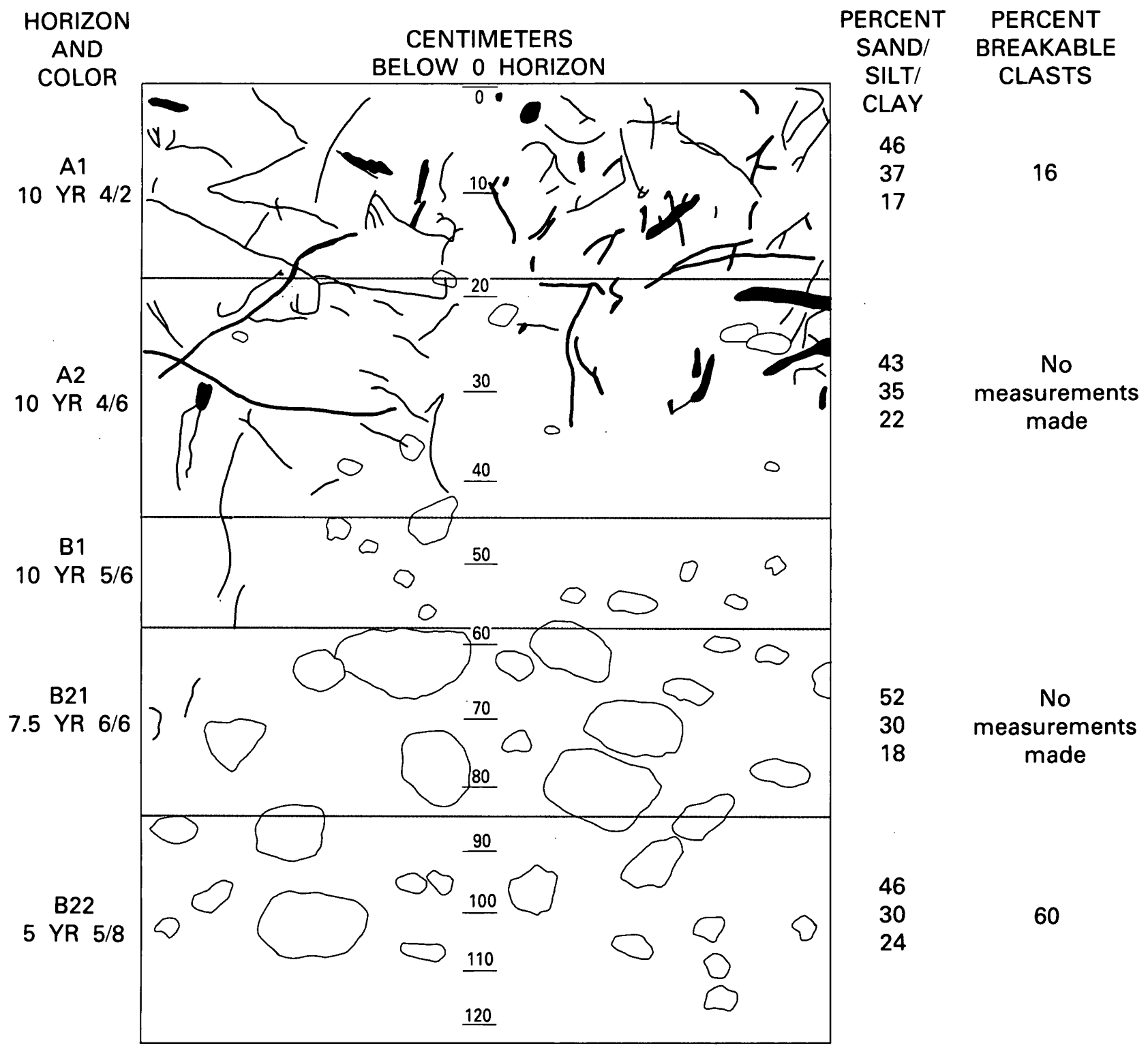

Figure 27.-Sketch of wall of soil pit at site 6D (fig. 2). Sketch was made from photograph taken at an angle to the wall, so that toward the base the vertical distance is compressed. Irregular black lines depict tree roots. Color designations are from Munsell Color (1975).

side of a soil pit at site $6 \mathrm{D}$ (fig. 2). This particular location shows little change in percent clay with depth, but there is a great difference in percent weathered clasts with depth as well as in the number and size of clasts.

The "youthfulness" of the upper horizons thus may have a pedogenic origin. At some locations, however, the thickness of this upper layer may be too great to be so explained. For example, consider site 65 (fig. 2), located at a cut through a lower nose. Table 5 shows the variation in weathering characteristics with depth at this site; the upper layer, distinguished by its percent weathered clasts and percent clay, is $1.4 \mathrm{~m}$ thick. An alternative origin for such a thick youthful layer is that a younger layer of colluvium was deposited on top of an older layer. The contact between the two layers at site

TABLE 5.-Changes in weathering characteristics with depth at site 65

[Site location is shown on figure 2]

\begin{tabular}{cccc}
\hline $\begin{array}{c}\text { Depth below surface, } \\
\text { in centimeters }\end{array}$ & Color $^{1}$ & $\begin{array}{c}\text { Percent weathered } \\
\text { sandstone clasts }\end{array}$ & Percent clay \\
\hline $20 \ldots \ldots \ldots \ldots \ldots$ & 7.5 YR 4/4 & 26 & 21 \\
$120 \ldots \ldots \ldots \ldots$. & 5.0 YR 4/6 & 28 & 22 \\
$200 \ldots \ldots \ldots \ldots$ & 2.5 YR 3/6 & 64 & 38 \\
\hline \multicolumn{2}{c}{ 1. }
\end{tabular}


65 (and at most similar sites) is so gradual that a pedogenic origin seems more likely. Until more definitive evidence is found, however, the alternative explanation should be considered possible.

\section{DISCUSSION}

\section{HILLSLOPE EVOLUTION MODEL AND COLLUVIUM}

The results indicate that colluvium on noses is somewhat older than that on side slopes and in hollows and that colluvium on lower noses is somewhat older than that on upper noses. This conclusion is compatible with the theory of hillslope evolution mentioned earlier and described in more detail elsewhere (Mills, 1981). According to this theory, bouldery colluvium protects the shale floors of hollows on the mountain flanks. In each hollow, the junction between the boulder-armored floor and the base of the unprotected shale side slope is the locus of greatest erosion. Runoff from rainstorms that have recurrence intervals on the order of perhaps 10 to 100 years incises gullies along the margins of the bouldery deposits but lacks the competence to disturb the deposits. Periodically, however, runoff from catastrophic rainstorms that have recurrence intervals on the order of perhaps 1,000 years or greater mobilizes the bouldery colluvium and deposits it in the gullies. The armored floor thus shifts laterally. Subsequently, new gullies are incised adjacent to the old ones. The result is the lateral migration of one or both walls of the hollow. Eventually, ridges between hollows are destroyed, and valley floors covered with bouldery colluvium become new interfluves. According to this theory, most colluvium is moved downslope in hollows. (Creep and slope wash, of course, are present on noses, although the boulder armor greatly reduces the rate at which they operate. In addition, because noses are characterized by convex downhill contours, debris eroded by these processes will be carried into adjacent hollows rather than straight down the nose.) Hence, once on an interfluve, colluvium essentially ceases to move until reeroded by a laterally migrating hollow; in most cases, colluvium on noses therefore is somewhat older than that in hollows, as appears to be the case in the present study area. This explanation does not directly account for the difference in degree of weathering, and thus presumably in age, between the upper and lower noses. The greater age of the lower-nose colluvium, however, may be the consequence of a lower rate of lateral migration of hollows on the gentler foot slopes. This lower rate would allow interfluves to attain greater ages than would be possible on the steeper upper slopes, so that their colluvial caps would also be older.

Because according to the above explanation most colluvium on noses was once transported in hollows, it therefore follows that such colluvium should be similar to that in modern hollows, differing only in ways that reflect degree of weathering. The findings support this prediction to some extent. Table 3, for example, shows that colluvium on upper noses does not differ from that in type $\mathrm{D}$ hollows in fabric strength or roundness, although it does differ in hue and percent weathered clasts.

Some differences between environments are difficult to explain, particularly the weakness in clast-fabric strength of upper-nose colluvium relative to that of lower-nose colluvium. Perhaps weathering intense enough to destroy many of the clasts in a deposit can also affect fabric, either by producing slight movement of the clasts or by selectively destroying those with certain orientations. A different origin for the two types of deposits cannot be ruled out, however, as an explanation for differences in fabric strength.

\section{AGES OF THE DEPOSITS}

Although no dates were obtained, probable age ranges can be established for the deposits on the basis of their degree of weathering. The assumption is made that the differences in weathering of the colluvial environments reflect mainly age rather than environmental factors. Although difficult to prove, certain data support this assumption. First, whereas differences in topography and vegetation may affect the nature of the soil profile developed, the large differences observed in clast weathering are difficult to explain on this basis. Second, a comparison of type $D$ with type $M$ hollows shows that these two environments differ significantly in no weathering characteristic (table 3), despite the fact that vegetation differences (and thus presumably the differences in microclimate and drainage) are as dramatic as those between hollows and noses. Third, it is difficult to understand how the relatively large differences in degree of weathering between upper and lower noses could be due solely to environmental differences, for the only real difference between the two is a relatively small one in slope angle.

Ciolkosz and others (1979) have noted that soils developed on colluvium in the Valley and Ridge province of Pennsylvania appear similar to soils on late Wisconsinan till farther north and therefore may have a similar age. From their profile descriptions, the soils they dealt with appear to be similar in development to those that in the present study area occur in hollows or on side slopes. On this basis, then, some of the hollow fills in 
this study may be late Wisconsinan in age, as was suggested earlier on the basis of fabric evidence. They are unlikely to be older. Side-slope deposits, however, are probably moving because of their high gradients and are unlikely to be older than late Holocene. With regard to the colluvium capping noses, a subjective comparison with glacial deposits of known age in the midwestern and northeastern United States suggests that it ranges from mid-Wisconsinan to pre-Illinoian in age; certainly some of the colluvium on lower noses seems likely to be pre-Illinoian. Houser (1980) has suggested, in the absence of any other data, that very approximate dates for terraces of the nearby New River can be obtained by dividing their heights above the modern river level by the regional erosion rate of 40 $\mathrm{mm} / 1,000$ yr determined by Hack $(1965,1979)$. This technique cannot be directly applied to the colluvial deposits, but such deposits can be crudely correlated by means of their weathering characteristics with terraces which can be so dated. An examination of the New River terraces (Mills and Wagner, 1985) shows that hues of 2.5 YR, common on lower noses, do not appear to occur in New River terrace deposits lower than $25 \mathrm{~m}$ above the river. Dividing by $40 \mathrm{~mm}$, this height yields an age of $625,000 \mathrm{yr}$ for these terraces and thus an approximate minimum age for the lower-nose deposits. Similarly, the percentage of weathered sandstone clasts shown by the lower noses is not seen on terraces lower than about $35 \mathrm{~m}$, representing an age of $875,000 \mathrm{yr}$. Although such evidence must be regarded as very tenuous because of differences in parent material, topography, and vegetation, it suggests that the age of the lower-nose colluvium is pre-Illinoian.

\section{TRANSPORT PROCESSES}

The material on side slopes very likely has reached its present location by creep and slope wash. As nose deposits are assumed to be essentially topographically inverted hollow deposits, the main problem is the manner in which the hollow deposits have been emplaced. The question of most interest is whether periglacial processes or debris flows are responsible. A review of research on particle size suggests that there is too much overlap between these two types of deposits to permit them to be distinguished on this basis. The degree of pebble roundness measured is greater than that reported previously for periglacial deposits, although this discrepancy is not definitive. Probably the most significant finding related to genesis is the difference in fabric strength between type $M$ hollows and type $\mathrm{D}$ ones. This difference suggests that gelifluction (or at least some form of laminar flow) may have been responsible for the emplacement of the type $M$ hollow deposits and debris flow (or at least some form of turbulent flow) for the type $\mathrm{D}$ hollow deposits.

Other characteristics besides particle attributes have been used to identify periglacial deposits. Benedict (1976), for example, noted that recent gelifluction deposits usually show some sorting and generally have a platy or sometimes vesicular structure. Organic-rich layers are also common due to the overrunning of soil humus by the gelifluction lobe during its downslope advance. Washburn (1973) noted that faint textural layering may be observed in gelifluction deposits. Denny (1956) reported that some presumably periglacial deposits in Pennsylvania showed rude stratification. Where bedding can be distinguished, contorted structures or "involutions" produced by freezing are often typical (Embleton and King, 1975, p. 46). None of these sedimentary features were observed in the present study area. Morphological characteristics also have been used to define periglacial deposits. For example, Benedict (1976) noted that gelifluction tends to produce sheets, benches, lobes, and streams. Again, no such forms were observed. However, because in Virginia gelifluction deposits would almost certainly be Pleistocene in age, sedimentological and morphological characteristics may well have been modified considerably during the Holocene. In particular, catastrophic floods have probably reworked many Pleistocene deposits. Dating of deposits probably will be required to demonstrate relict gelifluction deposits.

Colluvial deposits distant from the crests are unlikely to be the result of gelifluction; certainly their fabrics are incompatible with such transport. A fluvial origin, however, should be considered as an alternative to debris flow. Pierce (1966) discussed the origin of roundstone diamicton in some detail. The deposit in his study apparently is similar to the lower-nose colluvium in the present setting, although in Pierce's (1966) area it commonly occurred farther from the mountain crest and in the form of fans. Pierce (1966) considered two possible origins: debris-flow sediments and deeply weathered alluvial gravels secondarily enriched in clay. He considered the second origin more likely on the basis that (1) the diamicton is much poorer in immature clasts than is modern alluvium, suggesting a high degree of weathering; (2) debris flows on arid-region alluvial fans (where such deposits have been most studied) generally are interbedded with moderately well-sorted alluvial sediments and also commonly contain bubble cavities, whereas the diamicton shows neither; (3) pebble roundness increases with distance from the source, a characteristic more likely to be associated with stream deposits than with debris flows; and (4) the diamicton occurs along streams with gradients as low as 0.002 , probably 
too low to sustain movement of a gravel-bearing mudflow.

Pierce's arguments for an alluvial origin seem convincing with the exception of point (2), for deposition on fans in the Appalachians may take place only during catastrophic storms, so that "normal" alluvial sediments may not occur on them; also, bubble cavities probably could be readily eliminated by weathering. On the other hand, Pierce's arguments probably do not exclude a debris-flow origin for lower-nose deposits because highly weathered debris-flow deposits would also be deficient in immature clasts, and the slopes on the lower noses certainly are steep enough to permit movement of coarse debris flows.

\section{GEOMORPHOLOGY AND SEDIMENTOLOGY OF BOULDER STREAMS}

\section{A GENETIC CLASSIFICATION OF BOULDER STREAMS}

This section attempts to infer the origin of boulder streams in the Mountain Lake area by comparing their characteristics to those of boulder deposits whose origins are known. The manner in which scree is derived from bedrock will not be considered, although probably both frost riving and sapping of weaker units beneath a resistant formation are involved. Instead, the main concern is the manner in which scree is moved downhill and emplaced. The mechanisms by which boulders can be moved downhill fall into three general categories:

Type I: Gravity processes, including falling, rolling, sliding, and creep.

Type II: Periglacial processes, especially frost heave and gelifluction.

Type III: Debris flows associated with rare, catastrophic rainfalls.

These categories constitute a genetic classification of boulder streams which is most appropriate for a study emphasizing the paleoclimatic significance of boulder deposits. Many boulder deposits undoubtedly are compound in origin, but the above three types can be considered as endpoints. An important question to be addressed here is whether these three types can be distinguished on the basis of their geomorphology and sedimentology.

\section{PROCEDURE AND SEDIMENTOLOGIC CONSIDERATIONS}

Boulder streams considered to exemplify well the several types in the Mountain Lake area were selected for analysis. The streams studied thus did not represent a randomly selected sample; many boulder-stream sites probably have properties intermediate between the ones investigated. The present study, however, was designed to demonstrate the existence of different types of boulder streams rather than to characterize the average boulder stream. A separate classification system (A, B1, B2, and C) is used for the Mountain Lake boulder streams, whose origins are unknown, in order to avoid confusion with the genetic types (I, II, and III):

\begin{tabular}{|c|c|}
\hline $\begin{array}{l}\text { Classification used for } \\
\text { Mountain Lake boulder streams }\end{array}$ & $\begin{array}{l}\text { Possible genetic } \\
\text { equivalent }\end{array}$ \\
\hline $\begin{array}{l}\text { ype } \mathrm{B} 1 \\
\text { ype } \mathrm{B} 2\end{array}$ & $\begin{array}{l}\text { Type I } \\
\text { Type II (frost heave) } \\
\text { Type II (gelifluction) } \\
\text { Type III }\end{array}$ \\
\hline
\end{tabular}

An important property in the identification of boulder deposits is fabric. Most commonly the direction and dip of the $\mathbf{A}$ (long) axes of elongate clasts are measured, as discussed previously. However, where the clasts are tabular in shape, the orientation of the plane formed by the long and intermediate axes (the A-B plane) commonly is measured (fig. 28). When long axes are measured, by far the most common fabric is one in which the axes tend to lie parallel to slope, the average dip being downhill at an angle less than that of the slope

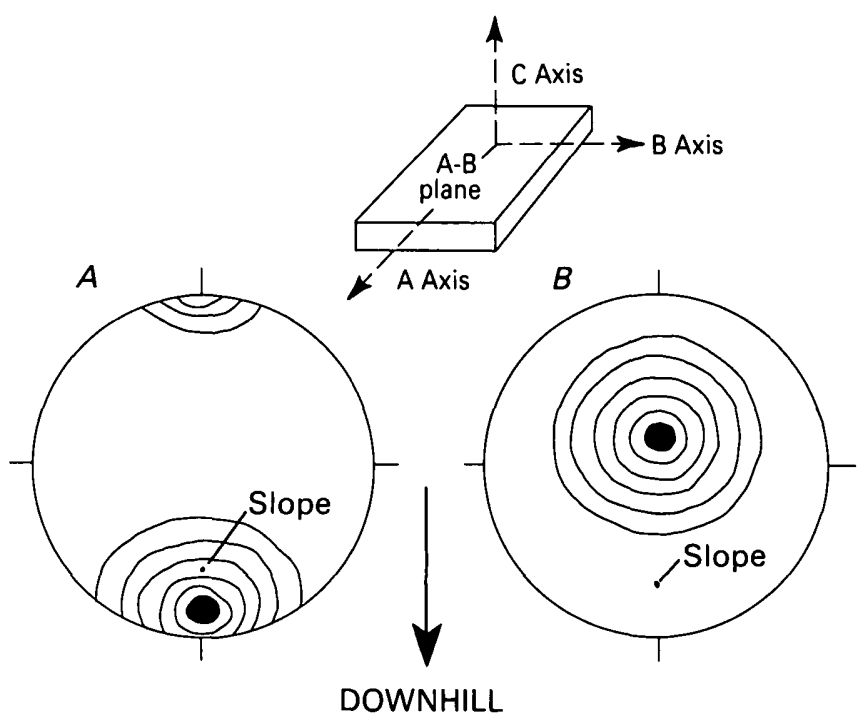

FIGURE 28.-Most commonly observed fabric patterns of slope deposits, plotted as contoured, equal-area (Schmidt, lower hemisphere) stereographic nets. Contour intervals are arbitrary. The line of slope is plotted for comparison. A, Most common pattern for long axes. Note that the preferred direction of the long axes (indicated by dark area on net) has a dip angle lower than that of the slope angle, showing uphill imbrication with respect to the surface. $B$, Most common pattern for short axes. The preferred dip angle of the A-B plane is found by subtracting the preferred angle of the short axes (dark area) from $90^{\circ}$. Note that in the example, this calculation yields a dip angle less than the slope angle, again indicating uphill imbrication. 
angle and thus giving an uphill imbrication with respect to the surface. Figure $28 \mathrm{~A}$ shows a typical example of this fabric as it appears on a contoured equal-area stereographic net; actual examples have been presented previously (fig. 23). When the A-B plane is measured, the average dip of this plane also generally is downslope at an angle less than that of the slope. In this case, the orientation of the A-B plane is determined by measuring the $\mathrm{C}$ (short) axis (which is the pole or normal to the A-B plane); a typical stereographic-net depiction of this short-axis pattern is shown in figure $28 B$. Note that the mode of the $\mathrm{C}$ axes is uphill, indicating a downhill dip of the A-B plane. The fabric patterns illustrated in figure 28 are so prevalent in many kinds of slope deposits that I have termed them the "standard" fabric patterns. Reporting such a pattern in fact supplies little information because the pattern is so common. Even where the standard pattern is found, however, the strength of the fabric (that is, the consistency of axial orientation) may constitute significant information, as illustrated by the variation of $s_{1}$ values in figure 25, discussed previously.

Because the boulders in the present study area tended to be tabular in shape (fig. 29), the orientation of the A-B plane was measured, although the A-axis orientation was also measured at some sites. Significant differences in Zingg shapes (Zingg, 1935) between sites were demonstrated by an analysis of variance, but figure 29 shows that this difference is not great and

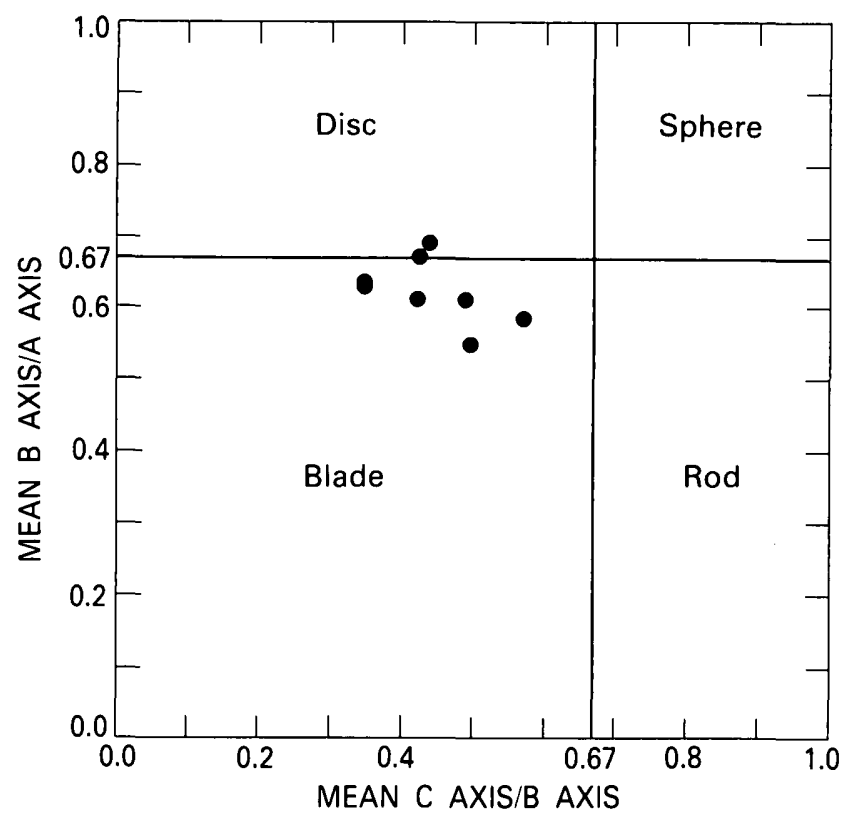

Figure 29.-Zingg diagram of boulder shapes at eight sites. Each dot represents the mean ratios of at least 25 boulders. Only boulders for which close estimates of the lengths of all three axes could be made were used. therefore is not likely to have affected the results. Boulder size varied somewhat more, intermediate diameters ranging from 393 to $791 \mathrm{~mm}$. Size differences, however, are less likely to affect fabric.

At each site, a tape was laid down the center of the boulder stream, and the orientation of the short axis (and long axis at some sites) measured for the boulder beneath each meter mark on the tape. The short-axis orientation was measured for 50 boulders at each site; the number for which the long-axis orientation could be measured commonly was smaller owing to boulders with indistinguishable $A$ and $B$ axes.

\section{POSSIBLE TYPE I DEPOSITS: PRODUCTS OF GRAVITY PROCESSES}

Most studies of type I boulder deposits have been made on alpine taluses. Generally these have high surface angles $\left(30^{\circ}-40^{\circ}\right)$ that may be equal to the angle of repose of the scree (Carson, 1977) or slightly less (Statham, 1976; Chandler, 1973). Slope profiles are straight or slightly concave (Gardner, 1971; Statham, 1976; Church and others, 1979). The upper layer of boulders has an open framework, but beneath this layer the interstices between the boulders may consist almost entirely of fines (Church and others, 1979). Size of the surface blocks generally increases (fall sorting) or decreases (reverse fall sorting) in a downhill direction (Gardner, 1971; Bones, 1973; Statham, 1976; Church and others, 1979). Investigators of long-axis fabrics generally have found the standard fabric to predominate (Gardner, 1971, McSaveney, 1972), although Caine $(1967,1969)$ found little preferred orientation. No shortaxis fabrics have been reported.

In the Mountain Lake area, possible type I deposits (here designated type A) are confined largely to the canyon of Little Stony Creek below the Cascades (fig. 3 ), where valley walls are the steepest in the area. The exceptionally steep slopes and instability of the deposits suggest that they are transported mainly by gravity processes.

Sites 156 and 137 (fig. 2) were selected for detailed study of type A deposits. Site 156 is on a boulder stream on the south flank of Butt Mountain at an elevation of $1,105 \mathrm{~m}$. The stream is 15 to $20 \mathrm{~m}$ wide and has a slope of $36^{\circ}$. As shown in figure 30, few trees grow on the surface of the stream near site 156, and the boulders, although lichen covered, are relatively angular. The clasts average $529 \mathrm{~mm}$ in intermediate diameter. Many of the boulders are unstable when walked upon. The surface boulders have an open framework; whether fines exist at depth could not be determined. The slope profile over several tens of meters is linear. 


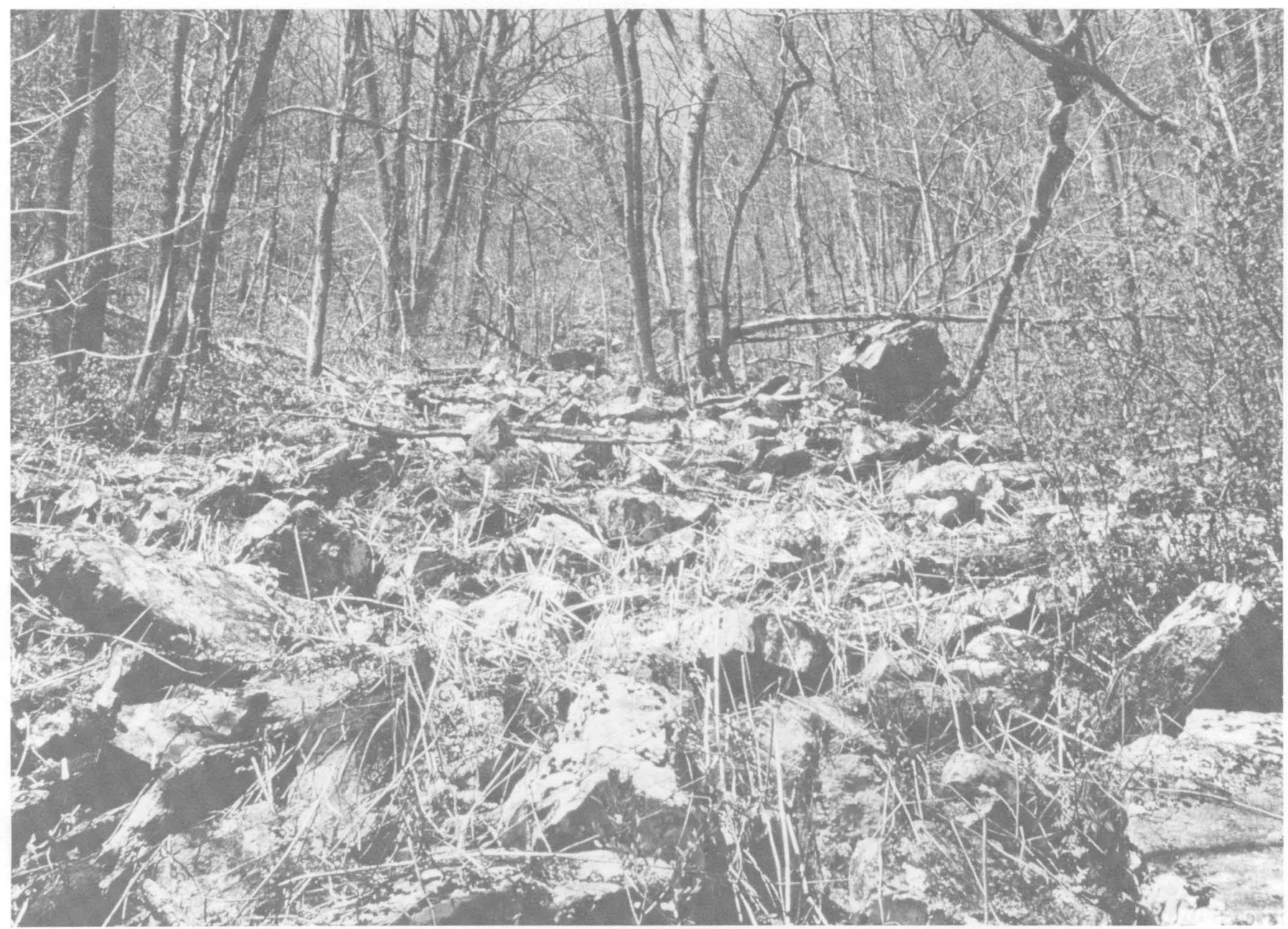

FIGURE 30.-Type A boulder stream near site 156. Note absence of trees on stream and the relative angularity of clasts. Slope angle is $36^{\circ}$. Site location is shown on figure 2 .

Short- and long-axis boulder fabrics are shown in figure 31 in the form of Schmidt nets. Note that the short axes have a preferred orientation of plunge in an uphill direction, which means that the A-B planes preferentially dip downslope. The $V_{1}$ dip for the short axes is $60^{\circ}$, corresponding to a mean A-B plane dip of $30^{\circ}$. As $30^{\circ}$ is less than the hillslope angle, the fabric thus shows uphill imbrication with respect to the surface, which is the standard fabric pattern. Figure 31 shows that the long axes also have a standard pattern, the $V_{1}$ dip being $22^{\circ}$.

Site 137 (fig. 2) is on a north-facing valley side slope at an elevation of $795 \mathrm{~m}$. The slope angle is $34^{\circ}$, and unlike conditions at site 156 , trees are plentiful, perhaps indicating greater stability, although the boulders appear to be nearly as unstable underfoot as at site 156 . Also in contrast to site 156, the blocks at site 137 have considerable moss cover, probably reflecting a moister rather than a more stable microenvironment. In other ways, including fabric patterns (fig. 31), the two sites appear similar.

The characteristics of these deposits thus resemble those described for type I deposits on high-angle alpine taluses. The only obvious difference is that in the present study area the deposits show no apparent change in clast size downslope. This similarity is of interest, for the settings of the Virginia talus obviously differs greatly from that of alpine talus. Besides the climatic difference, the "cliffs" above the deposits of this study area rarely are higher than $15 \mathrm{~m}$ or so and have restricted lateral extents. That the blocks rolled to their present position under the momentum provided by a fall from these cliffs, as is the case on alpine taluses, seems unlikely. Rather, it is probable that many of the blocks in this study area have moved to their present positions by creep or perhaps by sporadic sliding and tumbling, which may explain the lack of fall sorting or reverse fall sorting. 


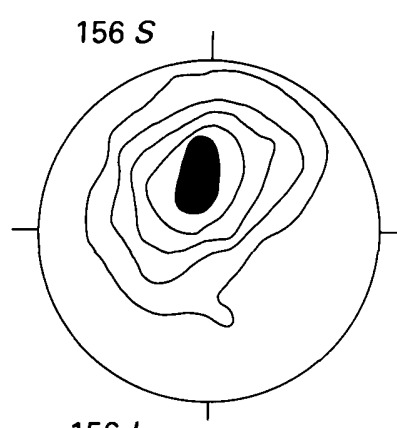

$156 L$

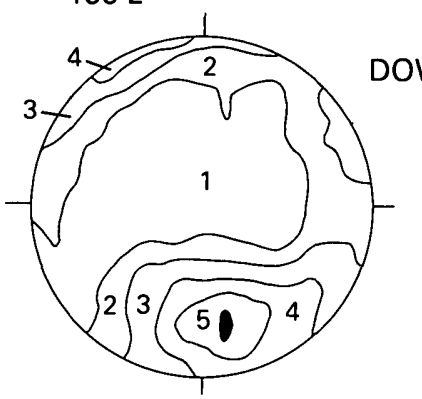

DOWNHILL

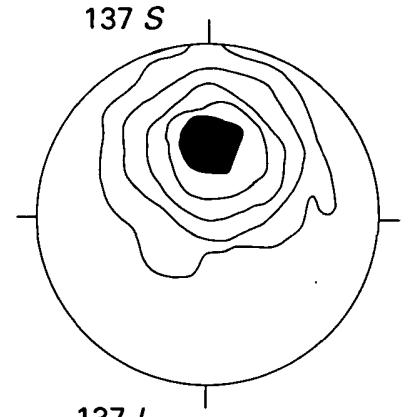

$137 L$

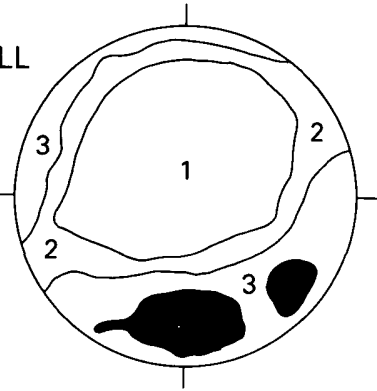

Figure 31.-Surface-boulder fabrics at sites 156 and 137 (type A boulder streams), presented as contoured Schmidt nets. In this and subsequent fabric illustrations, all nets have been rotated so that the downhill direction is toward the bottom. $S$ indicates short-axis fabrics and $L$ indicates long-axis fabrics. The black areas represent the densest concentration of axes. Where intervals have been numbered, higher numbers represent denser concentrations. Contouring is by Kamb's (1959) method in which the data-point densities on the Schmidt net are contoured at the desired significance levels. Contour interval is two standard deviations. Contouring was done by computer using a subroutine by Corbató (1965). Site locations are shown on figure 2 .

Although the deposits in the present study area may have been moving more rapidly in past times than at present, it seems unlikely that they are now completely stabilized. The large number of unstable boulders suggests that downhill motion of some kind persists. A lichen cover means little in a climate where lichens grow very rapidly, and even the presence of trees does not eliminate the possibility of intermittent movement on parts of the slope. At some locations trees appear to have been tilted by blocks piling up on their uphill sides, as observed by Fielder (1967). Evidence that scree is currently being produced at one locality in the study area has been discussed in the section titled "Little Stony Creek basin below the Cascades."

\section{POSSIBLE TYPE II DEPOSITS: PRODUCTS OF PERIGLACIAL PROCESSES}

\section{POSSIBLE FROST-HEAVE DEPOSITS}

Block or boulder fields, slopes, and streams in periglacial regions have been studied by many workers.

Dahl (1966) found block fields in Norway to have an open-block layer no thicker than $2 \mathrm{~m}$ and to show a transition to finer materials at depth. Caine (1968) found block fields in Tasmania to have an open-block layer no thicker than $3 \mathrm{~m}$ and also to show a transition to finer materials. He reported that the block-field material rests unconformably upon deeply weathered clay of pre-Pleistocene age with which there has been little mixing.

The crucial question for the present study is whether there are any characteristics of boulder deposits produced under periglacial regimes that can distinguish them from those produced under nonperiglacial regimes. One distinctive characteristic of at least some periglacial block streams is an on-edge orientation of clasts. This feature appears to be the product of frostheave, which involves upfreezing. Wherever frost heav. ing is prominent, tabular clasts within the soil tend to be on edge (Vorndrang, 1972; Washburn, 1980, p. 80). As there appears to be no other mechanism that has been shown to be capable of orienting boulder-size clasts in this manner, such an orientation certainly suggests an origin related to periglacial processes. Onedge fabrics have been reported for clasts in boulder streams and related deposits in the Appalachians. Smith (1953) and Potter and Moss (1968) have reported them in Pennsylvania, and Godfrey (1975) has found them in Maryland. Potter and Moss were able to define lobes within the Blue Rocks block field by the use of boulder fabrics.

The work of Clark (1968; oral commun., 1979), who studied sorted stone nets and stripes in the vicinity, indicates that periglacial relicts may well exist in the Mountain Lake area. Although no deposit even approaching the dramatic appearance of the Blue Rocks block field was encountered, many boulder streams containing large numbers of on-edge boulders were observed. These streams will be referred to as type B1 streams. Gradients range from $8^{\circ}$ to $30^{\circ}$, widths from $10 \mathrm{~m}$ to $100 \mathrm{~m}$, and lengths from $50 \mathrm{~m}$ to $800 \mathrm{~m}$. Generally locations characterized by large numbers of on-edge boulders occur relatively close to the mountain crests, although they can occur anywhere along the stream. All streams are forested. The surfaces are uneven and have pits too large to be explained by tree throw, although no clearly lobate forms similar to those reported by Potter and Moss (1968) could be detected. There appeared to be no regular changes in clast size downhill. Only one type B1 boulder stream was found exposed by an artificial cut. In comparison to the type A streams, these streams appear to be more weathered, more stable underfoot, and to contain more humic matter in the interstices between the boulders, although the uppermost layer of clasts still has an open framework. 


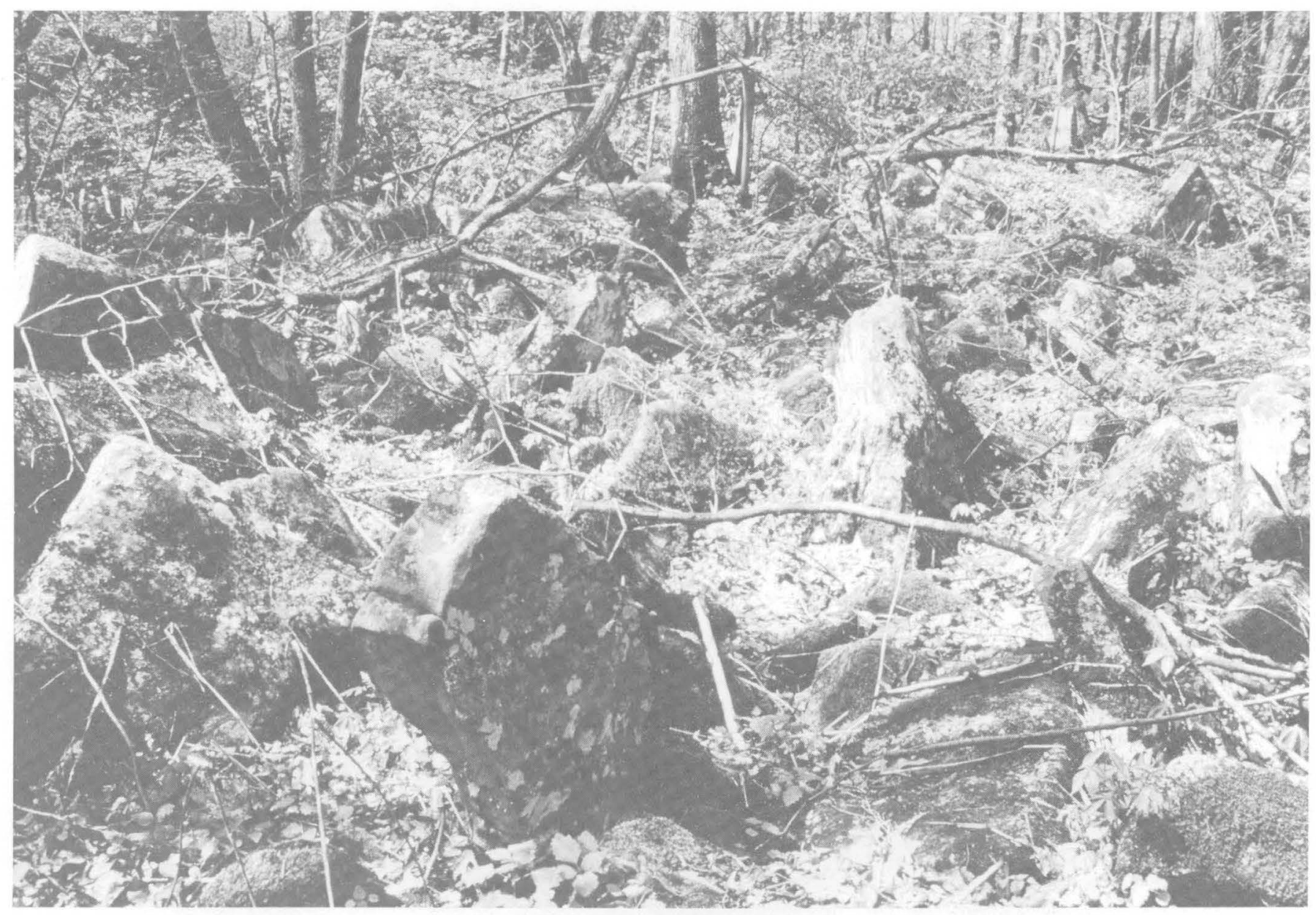

Figure 32.-Type B1 stream at site 141. Note the abundance of on-edge boulders. Boulder corners are more rounded than those in type A boulder streams (fig. 30). Site location is shown on figure 2 .

Four sites were selected for detailed study. Site 141 (fig. 2; elev. 1,065 m) is located along the crest of Doe Mountain near the contact between the Tuscarora Quartzite and the Juniata Formation. Figure 32 shows on-edge boulders in this stream. The gradient is $8^{\circ}$, and the average clast size (intermediate axis) is $791 \mathrm{~mm}$. Site 154 (fig. 2; elev. 1,110 m) is located on the Martinsburg Formation on the north flank of Salt Pond Mountain and has a gradient of $22^{\circ}$ and an average clast size of $661 \mathrm{~mm}$. Site 142 (fig. 2; elev. 1,115 m) is located on the Tuscarora Quartzite on the west side of a bog near the crest of Big Mountain and has a gradient of $8^{\circ}$ and an average clast size of $598 \mathrm{~mm}$. Site 100 (elev. $775 \mathrm{~m}$ ) is located on the Juniata and Martinsburg Formations on a north-facing slope near the gap between Gap Mountain and Sinking Creek Mountain (fig. 2) and has a gradient of $30^{\circ}$ and a mean clast size of $553 \mathrm{~mm}$.

Short-axis boulder-fabric plots for all four sites and long-axis plots for all but site 142 are presented in figure 33 . The three long-axis fabrics are all weak and display three different patterns. Site 100 shows a downslope alignment, site 141 shows some tendency for an on-end orientation, and site 154 shows a cross-slope preference. Of the four short-axis fabrics, only site 141 shows a pattern indicating steeply dipping A-B planes similar to the patterns reported by Potter and Moss (1968). The other three show only very weak preferred orientations and give no indication at all of the steeply dipping A-B planes. This finding seemed to contradict the intuitive impression that these deposits possess an exceptionally large number of steeply dipping blocks; therefore, an alternative method analyzing the dip angles of the A-B planes without reference to the direction of dip was used. In table 6, the numbers (out of a sample of 50) of clasts falling into each of four categories of A-B plane dip-angle values have been tallied. The categories are $0^{\circ}-10^{\circ}, 11^{\circ}-30^{\circ}, 31^{\circ}-60^{\circ}$, and $61^{\circ}-90^{\circ}$, selected so as to give an approximately sym- 
metrical distribution of expected number of clasts assuming a uniform distribution on a sphere, the commonly assumed null hypothesis for statistical testing of fabric data. ${ }^{2}$ Chi-square values were then calculated to show the size of the departure of the observed values from this expected distribution for each site.

The four sites on type B1 deposits show high chisquare values, chiefly owing to large numbers of clasts in the greater-than $-60^{\circ}$ category. The two sites on type A deposits also show significant chi-square values (though lower than those of the former sites), owing chiefly to a lack of clasts with dips of $10^{\circ}$ or less. Of the remaining sites (discussed below), two have significant fabrics because of large numbers of clasts between $11^{\circ}$ and $30^{\circ}$ and small numbers greater than $60^{\circ}$; the other two lack fabrics significantly different from a uniform distribution.

Thus, it is possible to demonstrate that the type B1 deposits have unusually large numbers of clasts with steeply dipping A-B planes and thereby are distinguished from the other types of block streams. The

\footnotetext{
${ }^{2}$ This number was determined as follows. On a Schmidt net a plane usually is represented by an arc. A plane can also be represented, however, by a point representing the pole to the plane or by a point representing the direction and angle of the dip of the plane. In the present analysis the latter method is used. In this manner any possible orientation of a boulder A-B plane can be represented by a point on the Schmidt net, which is a stereographic projection of a hemisphere. Assuming a uniform distribution of dip orientations on a hemisphere, the problem of determining the frequency distribution of dip-angle values reduces to one of determining the distribution of area on the hemisphere as a function of the angular distance from the base of the hemisphere. This problem in turn lends itself to a simple geometric solution. The area of a spherical segment defined by two parallel planes cutting a sphere is given by

$$
\mathrm{A}=2 \pi r h \text {, }
$$

where $r$ is the radius of the sphere and $h$ is the distance between the parallel planes. If one plane cuts through the equator of the sphere (thus dividing the sphere into two hemispheres), $h$ is given by

$$
h=r \sin \theta \text {, }
$$

where $\theta$ is the "latitude" (that is, the angular distance from the base of the hemisphere) at which the other plane cuts the sphere. Thus, for this situation,

$$
\mathrm{A}=2 \pi r^{2} \sin \theta
$$

and if, for simplicity, a value of $r$ is selected so as to make $2 \pi r^{2}=1.0$ (the $r$ value can be so selected because the absolute value of $r$ is irrelevant), then

$$
\mathrm{A}=\sin \theta .
$$

Note that the area of the entire hemisphere thus is $\sin 90^{\circ}=1.0$, so that areas of parts of the hemisphere can be expressed readily as percentages of the total area. For example, if $\theta=10^{\circ}$, then $A=\sin 10^{\circ}=0.174$ or 17.4 percent of the total. This means that $\mathbf{1 7 . 4}$ percent of the dip-angle values in a uniform distribution of dips on a hemisphere fall between $0^{\circ}$ and $10^{\circ}$. If there are 50 dip-angle values, this translates into 8.7 values, the figure used in table 1. To find the area between $10^{\circ}$ and $30^{\circ}$, the area between $.0^{\circ}$ and $30^{\circ}$ is first calculated: $A=\sin$ $30^{\circ}=0.500$. Then the area within $10^{\circ}$ of the equator is subtracted from the latter value: $0.500-0.174=0.326$. In other words, 32.6 percent of the dip-angle values fall between $10^{\circ}$ and $30^{\circ}$, corresponding to 16.3 values if there are 50 values total. A similar procedure is used to determine the percentages of values in other dip-angle categories. question arises, however, as to why the type B1 boulderstream clast fabrics are so much weaker than, for example, those measured by Potter and Moss (1968) in Pennsylvania. This weakness may indicate that the fabrics
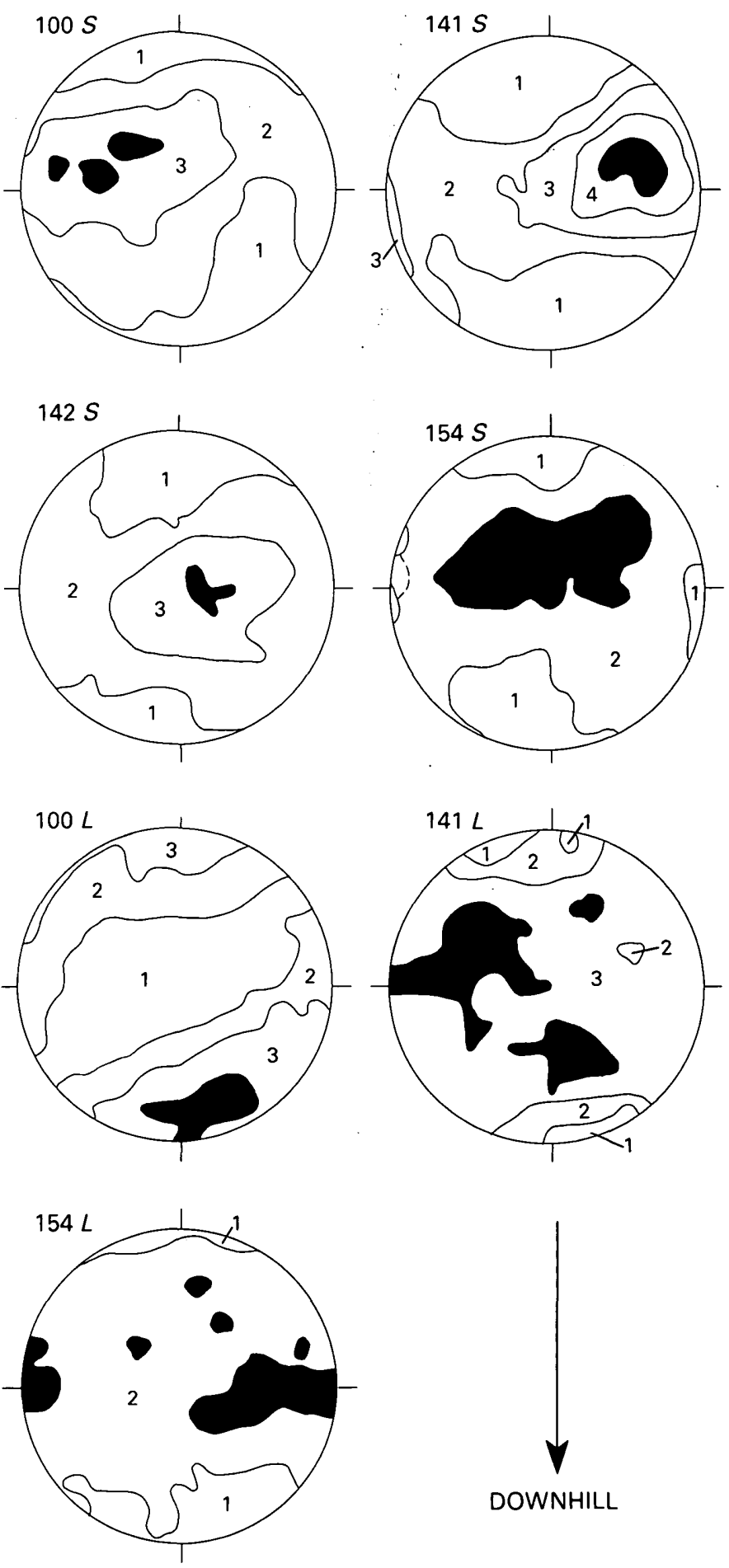

Figure 33.-Surface-boulder fabrics at sites 100, 141, 142, and 154 (type B1 boulder streams). $S$ indicates short-axis fabrics, and $L$ indicates long-axis fabrics. Site locations are shown on figure 2. 
TABLE 6. $-A-B$ plane dip distributions in boulder fabrics $(n=50)$

\begin{tabular}{|c|c|c|c|c|c|c|}
\hline \multirow{2}{*}{$\begin{array}{l}\text { Type of } \\
\text { boulder-stream } \\
\text { deposit }\end{array}$} & \multirow{2}{*}{$\begin{array}{c}\text { Site } \\
\text { number }\end{array}$} & \multicolumn{4}{|c|}{ Number of clasts with A-B plane dips of: } & \multirow[b]{2}{*}{$\underset{\text { square }}{\text { Chi }}$} \\
\hline & & $0^{\circ}-10^{\circ}$ & $11^{\circ}-30^{\circ}$ & $31^{\circ}-60^{\circ}$ & $61^{\circ}-90^{\circ}$ & \\
\hline A $\ldots \ldots$ & 137 & 0 & 16 & 25 & 9 & ${ }^{1} 12.0$ \\
\hline A $\ldots \ldots \ldots . .$. & 156 & 1 & 18 & 21 & 11 & ${ }^{1} 10.2$ \\
\hline B1 ......... & 100 & 3 & 10 & 19 & 18 & ${ }^{1} 25.3$ \\
\hline B1 ......... & 141 & 1 & 13 & 14 & 21 & ${ }^{1} 39.0$ \\
\hline B1 .......... & 142 & 4 & 10 & 18 & 18 & ${ }^{1} 24.0$ \\
\hline B1 ......... & 154 & 0 & 9 & 25 & 16 & ${ }^{1} 27.3$ \\
\hline $\mathrm{C} \ldots \ldots \ldots$ & 75 & 9 & 31 & 8 & 2 & ${ }^{1} 22.4$ \\
\hline $\mathrm{C} \ldots \ldots \ldots \ldots$ & 140 & 10 & 20 & 17 & 3 & 3.2 \\
\hline $\mathrm{C} \ldots$ & 151 & 5 & 19 & 20 & 6 & 2.3 \\
\hline C ............. & 153 & 7 & 32 & 10 & 1 & ${ }^{1} 24.1$ \\
\hline \multicolumn{7}{|c|}{$\begin{array}{l}\text { Expected, assuming } \\
\text { uniform distribution }\end{array}$} \\
\hline
\end{tabular}

were formed by nonperiglacial processes. On the other hand, it may simply result from the fact that Pleistocene frost action was less intense in Virginia than in Pennsylvania. Also, because of the absence of trees, fabrics on the Pennsylvania deposits may be better preserved.

Site 100 (figs. 2, 34) is an atypical type B1 boulder stream because of its small size and steep gradient. However, it has the unique advantage of a completely exposed cross section, and for this reason it was studied in some detail. To portray the surface distribution of blocks graphically, I hand-surveyed topographic profiles up and also across the stream and measured clast diameters at regular intervals along the survey lines. Along the longitudinal profile (fig. 35) boulder diameter was measured every $3 \mathrm{~m}$ and is indicated by the length of the vertical line. In the field, the stream appears to begin at $X$, although a few large clasts occur above this point. Note that there are no large blocks on the Tuscarora Quartzite itself, the blocks of the boulder stream perhaps having been derived from the base of the formation. Also note that there is no semblance of a cliff above the head of the boulder stream, a finding true of many other B1 boulder streams. The downstream end of the stream has been destroyed by road construction.

The transverse profile (fig. 36), with boulder-diameter measurements every $0.5 \mathrm{~m}$, shows a rather abrupt transition from the side slopes to the 15 -m-wide boulder stream. This abruptness shows that the boulder stream is a distinct entity, not merely an apparent one formed by runoff scouring the leaves and forest litter from the floor of the hollow. This situation was typical of many streams. The boulder layer appeared to be about $1 \mathrm{~m}$ or so thick.

The boulder stream is underlain by a channel-shaped trough cut into residuum of the Martinsburg Forma-

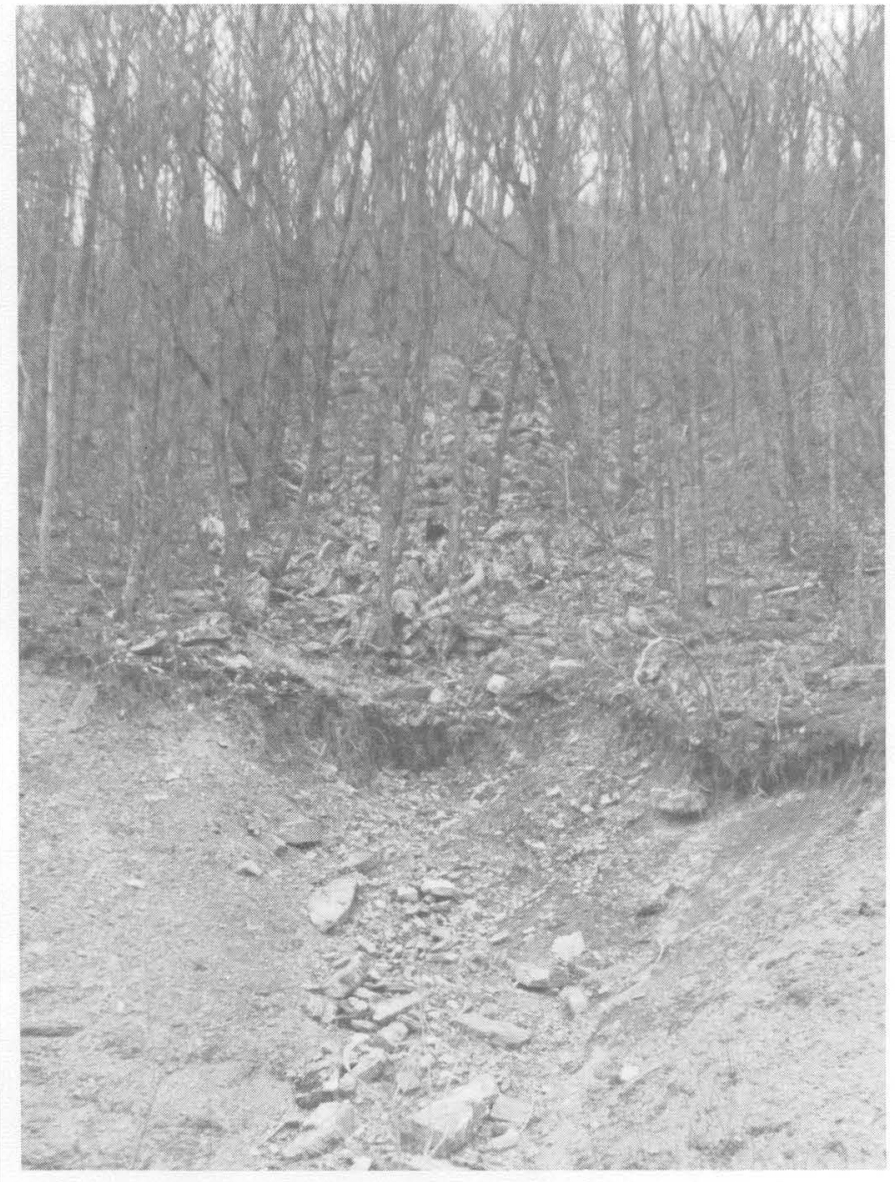

FigurE 34.-Site 100 boulder stream (type B1). Exposure reveals a colluvium-filled trough eroded into Martinsburg Formation residuum (partly obscured by slumping) beneath the surface boulders. An outline of the trough cross section is shown in figure 38 . The thickness of the surface boulder layer is greater than appears here, for most of the boulders at the top of the cut have fallen down. Site location is shown on figure 2.

tion and filled with colluvium. (This trough appears, though not clearly, in fig. 34.) A section on the right side of the cut through the trough (fig. 37) reveals a stony sandstone-rich diamicton, relatively free of boulders, which contains an increasing number of yellowish clasts of weathered Martinsburg shale downward. There is a gradational contact between the diamicton and the Martinsburg residuum. Note the decrease in percent sand and corresponding increase in percent clay as the Martinsburg shale component increases. Weathered in situ Martinsburg shale occurs $2 \mathrm{~m}$ or so below the base of this section. The structure of the boulder stream here seems comparable to that described for streams studied by Dahl (1966) and Caine (1968) in that the boulders are underlain by colluvium and the colluvium becomes finer at greater depths. 


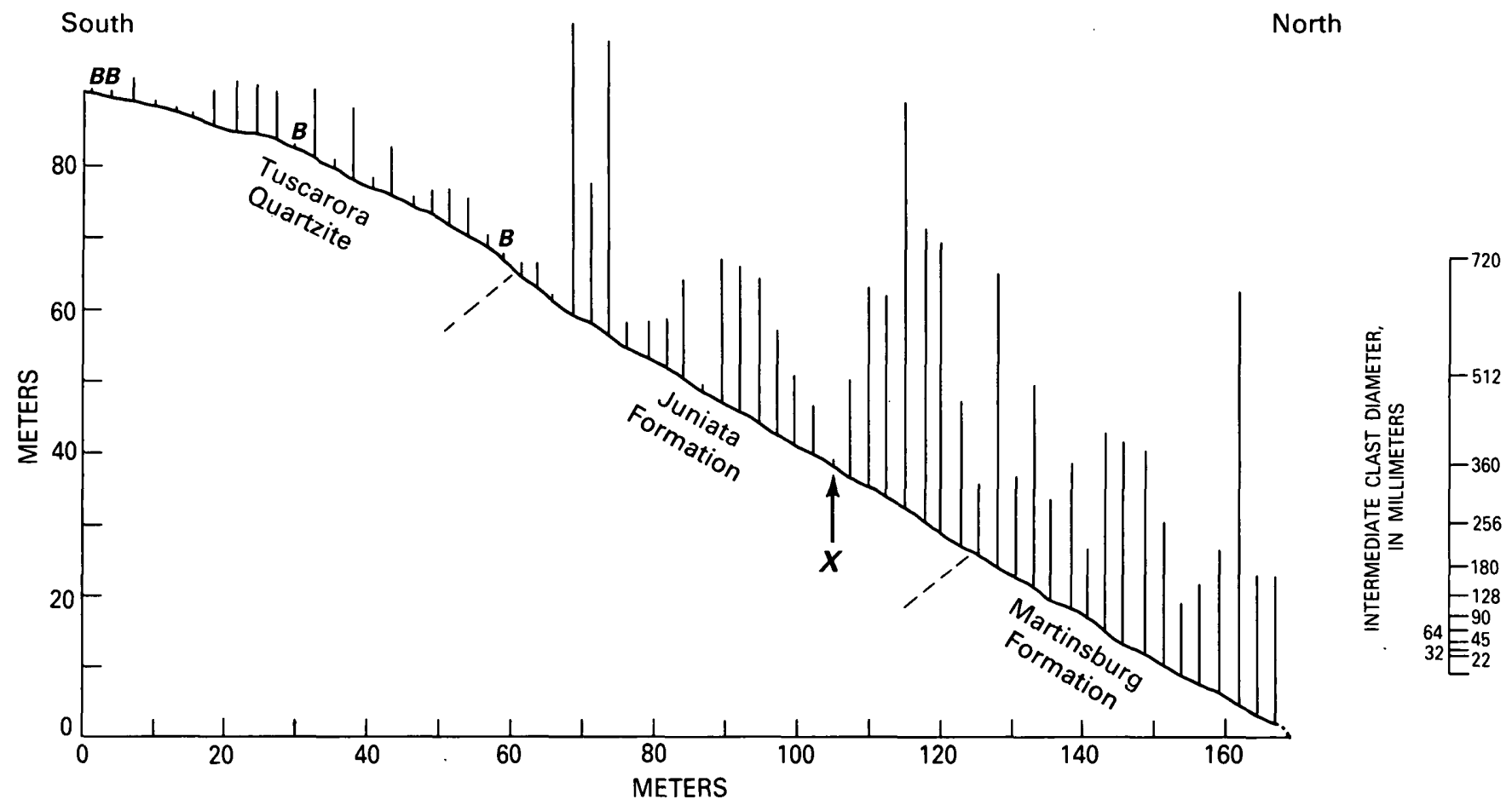

Figure 35.-Hand-surveyed longitudinal topographic profile along the central axis of the site 100 boulder stream, measured from the crest of Gap Mountain to the lower end of the stream. Boulder size was measured to the nearest $1 / 2 \phi$ at $3-\mathrm{m}$ intervals and is indicated by the length of the vertical line. Size scale is logarithmic, owing to the extreme size range. Contacts are approximate. $X$ marks the location at which the boulder stream appears to head. $B$ marks bedrock outcrops. Site location is shown on figure 2.

Study of long-axis fabrics of pebbles and cobbles in the cut yielded an interesting result. Fabrics were measured at four locations within the trough cross section, and the results are presented as contoured Schmidt nets (fig. 38). The two fabrics near the center of the trough show a strong standard fabric pattern parallel to the long axis of the boulder stream. The two fabrics near the sides, however, show orientations intermediate between this direction and a transverse one. Such oblique preferred orientations imply that material is transported laterally into the trough from the side slopes as well as directly down the slope of the boulder stream. Similar trough-shaped contacts between colluvium and residuum were not seen beneath other boulder streams, probably because of inadequate exposures.

\section{POSSIBLE GELIFLUCTION DEPOSITS}

Although frost heave appears to produce a distinctive sedimentologic feature, gelifluction, another common periglacial process, apparently does not. Benedict (1976) found gelifluction to produce the standard fabric pattern rather than an on-edge pattern. Deposition by gelifluction may explain why many workers in periglacial regions have failed to find on-edge fabrics in boulder deposits (for example, Cailleux, 1947; Klatka, 1961, 1962; Dahl, 1966). In addition, as discussed previously, other sedimentary characteristics of gelifluction deposits are either not very distinctive or are unlikely to be preserved very long after gelifluction ceases. Thus, unlike boulder deposits emplaced by frost heave, deposits emplaced by gelifluction may be difficult to distinguish from those emplaced by nonperiglacial processes such as debris flows. Type B2 boulder deposits, those thought most likely to be of gelifluction origin, were covered by dense rhododendron growths, and no surface boulder fabrics were measured. However, the fabrics of these deposits appeared to differ little from those of type $\mathrm{C}$ deposits (possible debris-flow deposits), and as discussed in the following section, only subsurface characteristics appeared to offer the possibility of distinguishing these two types of boulder streams.

POSSIBLE TYPE III DEPOSITS: PRODUCTS OF DEBRIS FLOWS

In the Appalachian region, deposits of catastrophic floods (type III) have received less attention than have possible type II deposits. Hack and Goodlett (1960) 


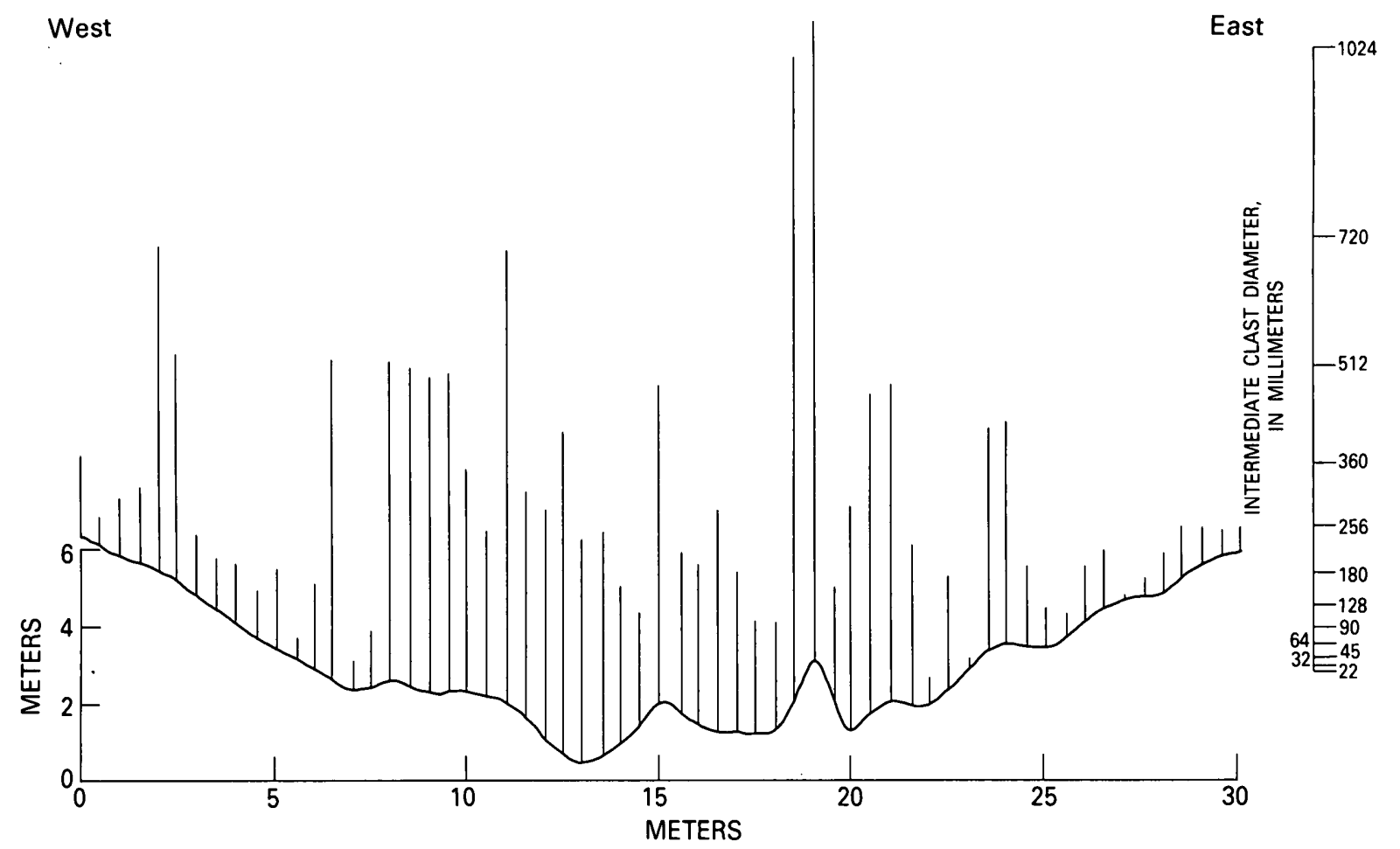

Figure 36.-Hand-surveyed transverse topographic profile across site 100 boulder stream. Boulder size was measured every $0.5 \mathrm{~m}$ and is indicated by the length of the vertical line. Boundaries between the boulder stream and the side slopes, as defined texturally, are rather abrupt. Bedrock is the Martinsburg Formation. Site location is shown on figure 2.

and Bogucki (1970, 1976) have given brief descriptions of such deposits, but the most detailed description is that by Williams and Guy (1973) of the flood deposits laid down in Nelson County, Va., during Hurricane Camille in 1969. Deposits at the base of hillslopes were found to lack any recognizable sedimentary features such as bedding, lamination, or crossbedding. In other words, they were similar in this regard to many gelifluction deposits. On the other hand, the authors reported that fabrics appeared to be very weak (although they made no actual measurements). If this finding is generally true for catastrophic flood deposits on hillslopes throughout the Appalachians, it may provide a basis for distinguishing such deposits from gelifluction deposits because the latter, as discussed earlier, generally have strong fabrics. Deposits of possible debrisflow origin are referred to as type $\mathrm{C}$.

Many boulder streams in the Mountain Lake area display a standard fabric pattern and thus are consistent with either a gelifluction or debris-flow origin. Both differ from the type B1 streams in ways other than fabric. First, they generally occur farther from the crest and have larger drainage basins. Second, their surfaces are somewhat smoother because pits are generally absent. Third, although an open framework may be present, commonly the interstices of the upper boulder layer are filled with fine sediment, and individual blocks may be partly covered with finer sediment or may be resting on the surface of a fine-grained substrate rather than being in contact with other blocks. Fourth, the boulders generally are less stable (although much more stable than type A streams). Similarities to type B1 streams include gradient, length, width, and presence of trees. Boulder roundness is generally comparable, although at some locations it is greater than that associated with type B1 deposits.

Four sites were selected for detailed study; all overlie the Martinsburg Formation. Site 75 (fig. 2; elev. 1,035 $\mathrm{m}$ ) is located on the southwest slope of Bean Field Mountain and has a gradient of $17^{\circ}$ and a mean clast size of $543 \mathrm{~mm}$. Site 140 (fig. 2; elev. $1,025 \mathrm{~m}$ ) is also located on the southwest slope of Bean Field Mountain and has a gradient of $15^{\circ}$ and a mean clast size of 514 $\mathrm{mm}$. Site 151 (fig. 2; elev. $840 \mathrm{~m}$ ) is located on the south flank of Johns Creek Mountain and has a gradient of $22^{\circ}$ and a mean clast size of $507 \mathrm{~mm}$. Site 153 (fig. 2; elev. $1,120 \mathrm{~m}$ ) is located on the northwest flank of Salt Pond Mountain and has a gradient of $25^{\circ}$ and a mean clast size of $572 \mathrm{~mm}$. Sites 75 and 153 are on streams that lie on the floors of hollows (fig. 39), whereas sites 


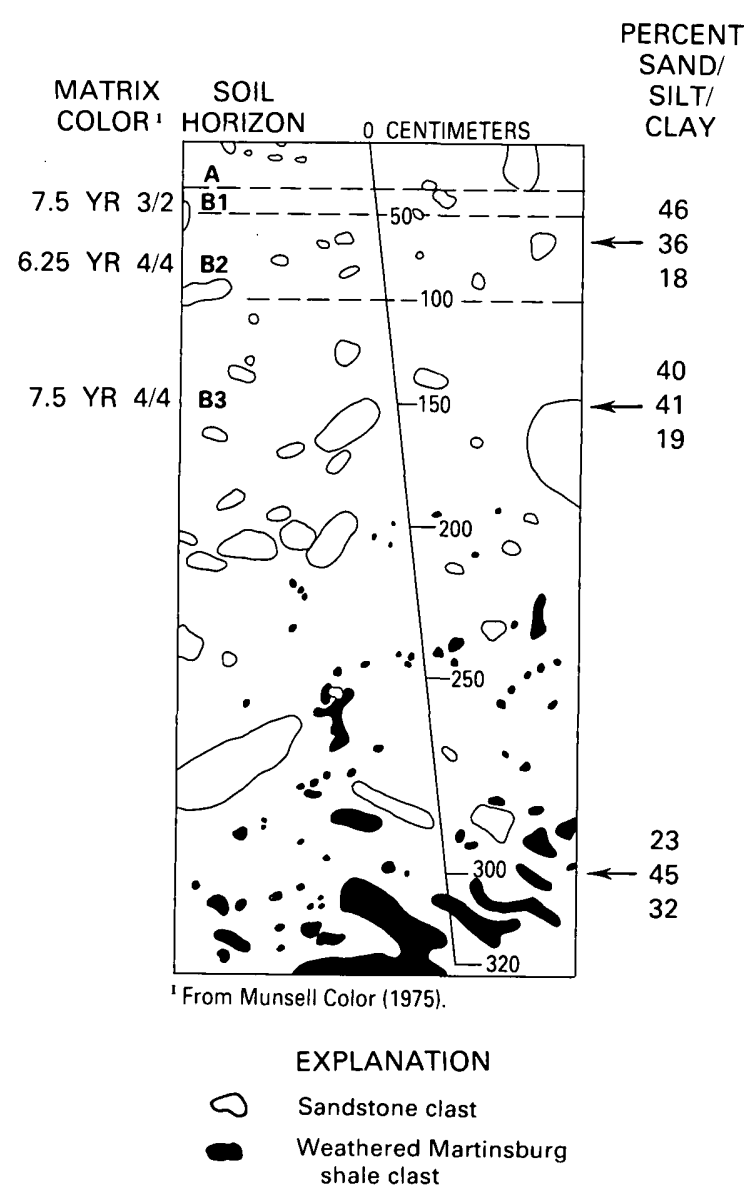

Figure 37.-Close-up of vertical section on right side of trough cross section at site 100 (fig. 2). This sketch was made from a photograph taken at an angle, so that vertical scale is compressed toward the top. The oblique scale was drawn from a tape-measure included in the photograph. The B2 horizon, defined on the basis of color (reddest hue), occurs approximately between $50 \mathrm{~cm}$ and $100 \mathrm{~cm}$ on the tape. Above the $200-\mathrm{cm}$ mark there are no shale clasts; such clasts increase downward until, below the $300-\mathrm{cm}$ mark, they are the only ones present.

140 and 151 are on streams that occupy positions several meters above the lowest point of the hollow cross section. Sites 140 and 151 thus probably are older, although the age difference may not be great. Sites such as 140 and 151 often have convex-up crossvalley profiles (fig. 40).

Short-axis boulder fabrics from all four sites and long-axis fabrics from two sites are presented in figure 41. All show a standard short-axis fabric pattern, although the preferred orientation is somewhat stronger at sites 75 and 153. This difference in strength is also shown by the dip angles alone: Table 6 shows that the dip-angle distributions at sites 75 and 153 differ significantly from a uniform one, whereas the distributions at sites 140 and 151 do not. Thus, the topograph-

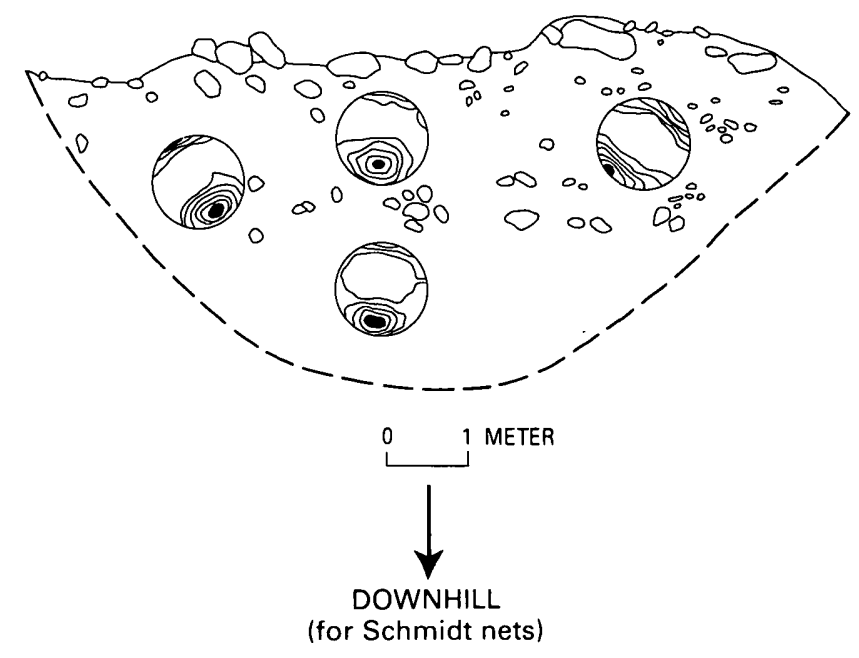

Figure 38.-Cross section of trough beneath site 100. This cross section can be discerned vaguely in figure 34 . Each Schmidt net shows the fabric pattern based on long axes of clasts in colluvium at that location. All nets have been rotated so that the downhill direction (parallel to the long axis of the boulder stream) is toward the bottom.

ically younger type $\mathrm{C}$ sites have the stronger fabrics, although whether this is a general relationship is not known. Site 153 shows a weak standard long-axis fabric pattern, whereas site 140 shows a very weak oblique tendency.

Deciding between a gelifluction and a debris-flow origin for these deposits is difficult. Weak long-axis boulder fabrics appear to be typical of these streams, although only two fabrics were actually measured. These fabrics probably support the catastrophic flood hypothesis more than the gelifluction one, for the latter should produce strong boulder orientations according to Lundqvist (1949). Previous workers have focused attention on streams having convex-up transverse profiles (such as that shown by site 140 in fig. 40). Fiedler (1967) considered such deposits to be relict rock glaciers. Pierce (1966) termed such features "rubble ridges" and dismissed the rock-glacier hypothesis because the streams are much too thin to have allowed such movement. (Wahrhaftig and Cox (1959) have suggested that a minimum thickness of $30 \mathrm{~m}$ is required for flow of rock glaciers). Pierce (1966) also doubted that rubble ridges were the result of debris slides or avalanches because they did not display the forms he considered characteristic of such features. Convex-up profiles may also be explained simply as a result of postdepositional topographic reversal, for the unprotected colluvium or shale residuum on either side of the stream may undergo greater erosion than that which is covered with Tuscarora boulders. Pierce (1966), however, thought this explanation inadequate, for it could not explain the 


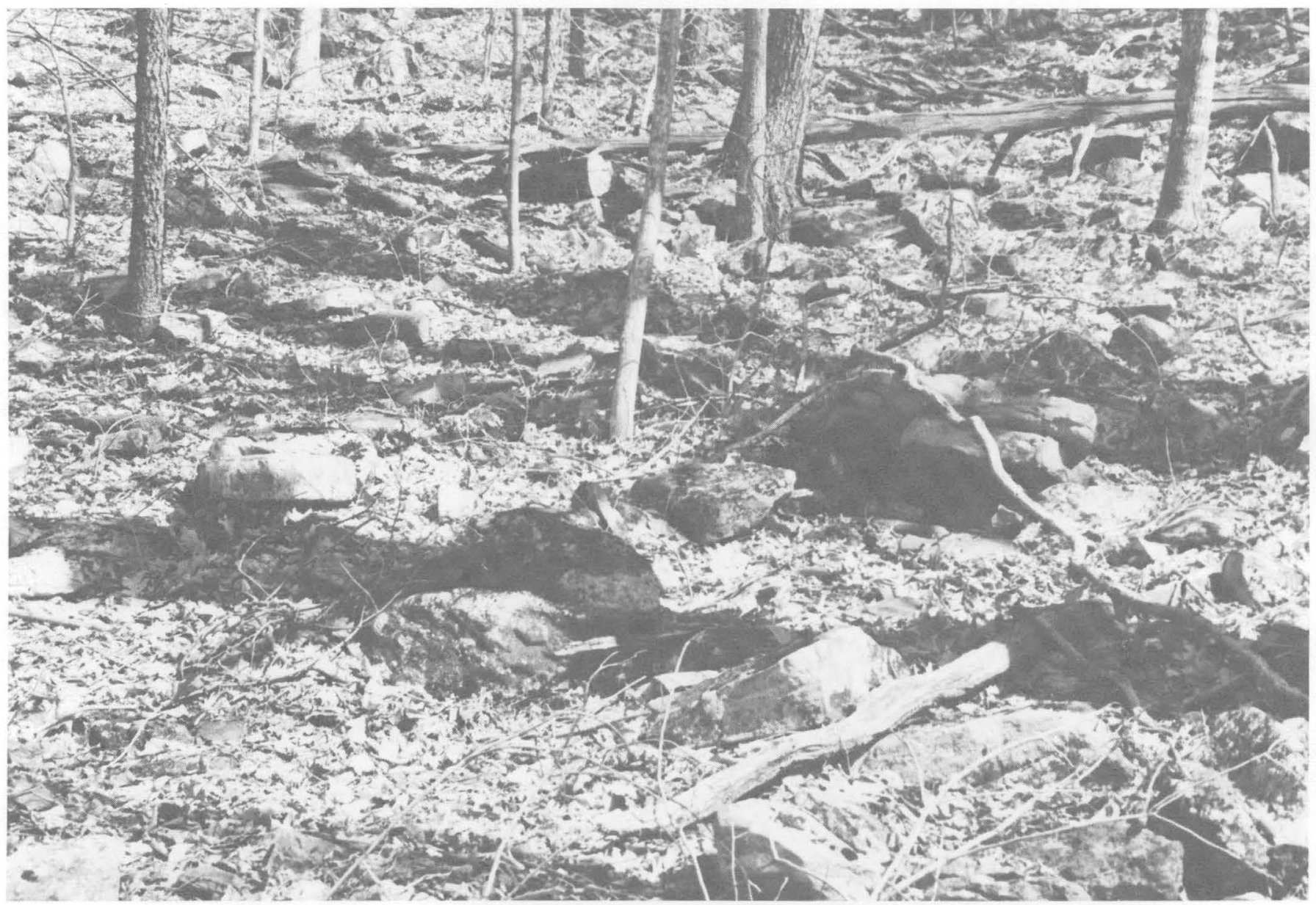

FIGURE 39.-Boulder stream at site 75. Deposits occur on lowest part of hollow floor. Site location is shown on figure 2.

relatively steep toes on some of the ridges. By "steep" Pierce meant $14^{\circ}$, which contrasted with a $6^{\circ}$ slope on the surface of the features. In the present study area, however, no really steep toes on such features were observed, so this hypothesis appears to be more tenable. In addition, if only morphology is considered, it would seem that deposits with steep toes could originate either as gelifluction lobes or as debris dams associated with catastrophic floods. Thus, external form alone probably sheds little light on the origin of such deposits.

The fabrics in the underlying colluvium may allow type B2 and type C boulder streams to be distinguished. As discussed earlier, colluvial fabrics measured in moist hollows fairly near the mountain crest (type $\mathrm{M}$ hollows) tend to be much stronger than those measured in dry or distal hollows (type D hollows). It was hypothesized that the fabrics in type $\mathrm{M}$ hollows are the product of gelifluction or some other form of laminar flow, whereas those in type $\mathrm{D}$ hollows are the product of turbulent flows associated with catastrophic flooding. Since both types of streams occur in both of the above- mentioned types of hollows, these streams can be discriminated by colluvial fabric strength: Type B2 boulder streams are those with strong subsurface fabrics and, therefore, are more likely to be the product of gelifluction; type $\mathrm{C}$ streams are those with weak subsurface fabrics and, therefore, are more likely to be the product of catastrophic floods. Of course, distinguishing type $\mathrm{B} 2$ and type $\mathrm{C}$ streams on the basis of subsurface fabric strength means that identification is possible only where the subsurface exposures are observable. On the basis of weak fabrics in subsurface colluvium, the boulder streams at sites $75,140,151$, and 153 (fig. 2) were classified as type C. On the basis of strong fabrics in subsurface colluvium, the streams at sites 69,160 , 164, and 165 (fig. 2) (on which no boulder fabrics were measured, owing to the dense rhododendron growths) were classified as type B2.

\section{OBSERVATIONS ON RELATIVE AGES OF THE DEPOSITS}

Relative age is of interest in comparing the several types of boulder streams. If the type B1 deposits, for 


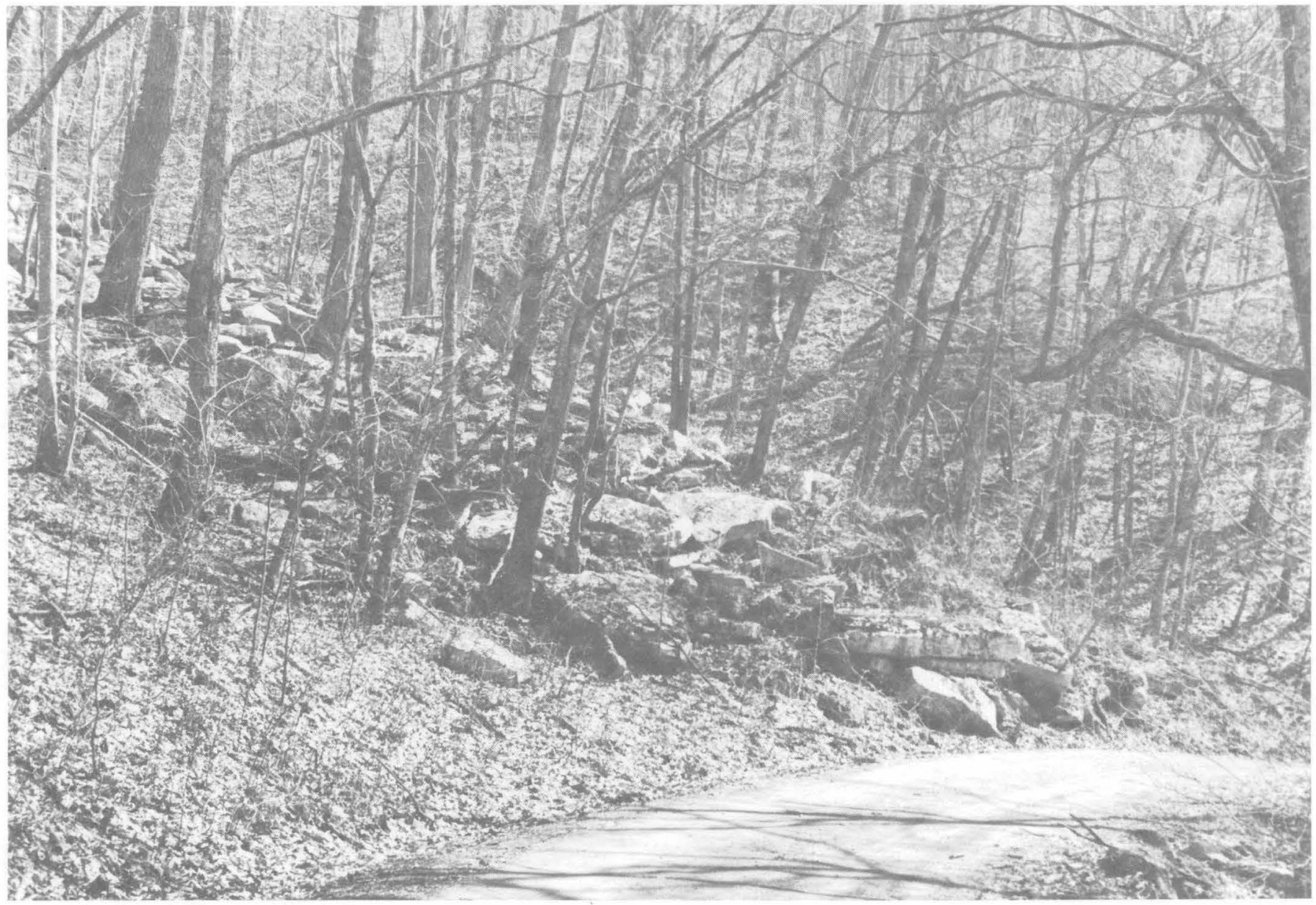

FigURE 40.-Boulder stream at site 140. Deposit has convex-up transverse topographic profile and lies above the lowest part of the hollow floor. Site location is shown on figure 2.

example, are indeed Pleistocene relics, then it is probable that they are older and, therefore, likely to be more weathered than many type $\mathrm{C}$ deposits. In an attempt to see whether the type B1 deposits were older than type C deposits, I compared some of these deposits with respect to several relative-age dating criteria. The two deposits showed few differences in weathering rinds, rounding, and pitting of boulders, which perhaps should be expected in a forested area. Birkeland (1973) pointed out that in Colorado, forest fires, which cause spalling of the surface layers of boulders, are apt to obscure such differences between deposits of different ages. Better results were obtained by counting the percent of cracked boulders at sites. Four counts were made, two on type $\mathrm{B} 1$ boulder streams and two on type $\mathrm{C}$ streams. The results are presented in table 7. Type B1 deposits have far more cracked boulders. The majority of cracks are along bedding planes, but there are also many cracks oblique to or at right angles to bedding. Whether the cracking was caused by frost riving is not known, but clearly the cracking suggests that the type B1 boulders are older. Although no counts were made, the percent of cracked boulders on type B2 deposits appeared to be variable but somewhat less than that at type B1 sites, which may reflect reworking of the surface of the B2 boulder streams. Type A deposits appeared to have very few cracked boulders, as might be expected, for these deposits appear too unstable to be very old.

Another observation that may bear on relative age is that the boulders in type B1 streams commonly are more rounded than those in type A streams. As boulders in neither type of stream presumably have been rounded by water transport, this difference may be due to the greater age of (and hence greater weathering of) type B1 streams. Rounding was much more variable in type $\mathrm{C}$ streams, but as rounding in such streams may have been caused in part by water transport, this property cannot be used as a relative-age index. In addition, the boulders in type B1 streams commonly are more stable than either type A or C streams, again suggesting a greater age for the type B1 streams. 

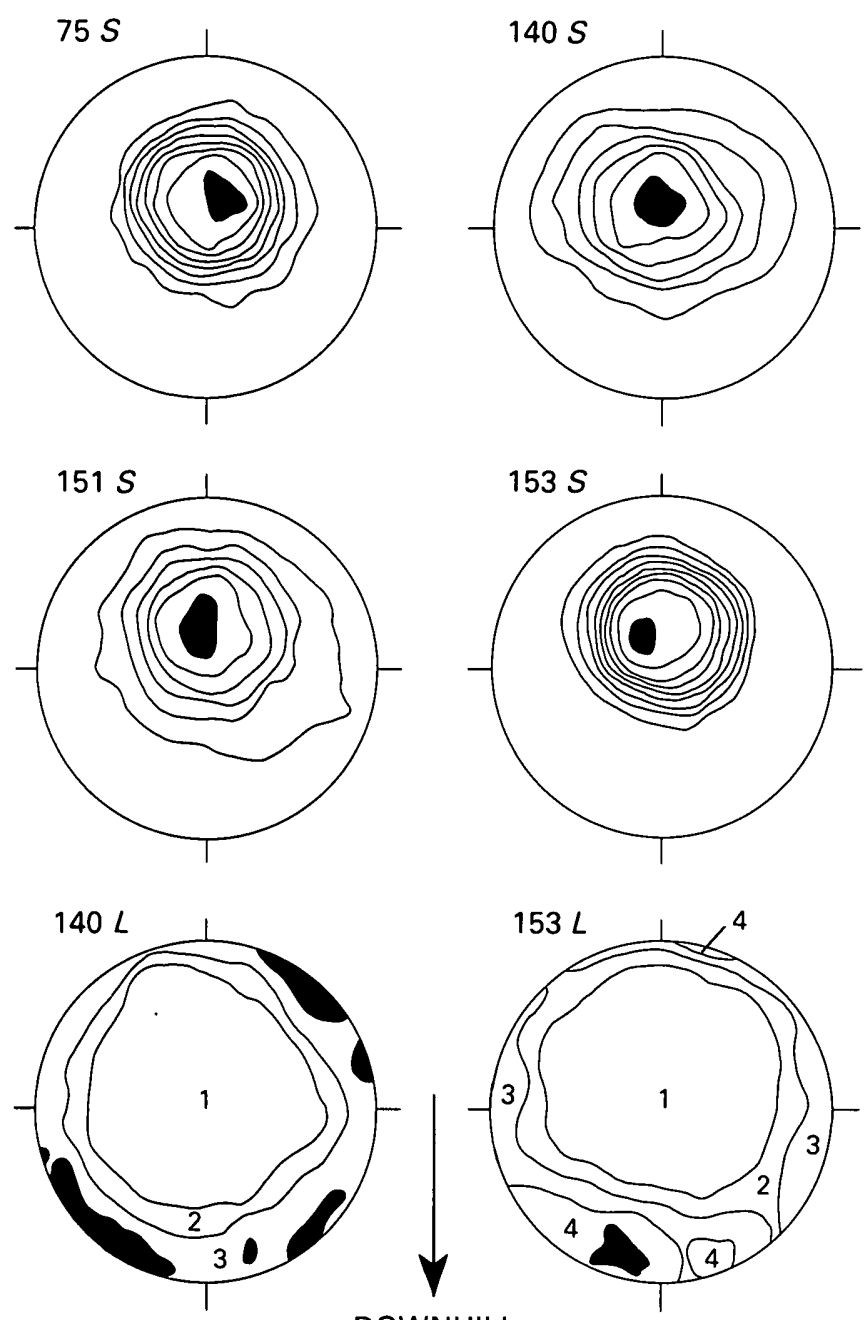

DOWNHILL

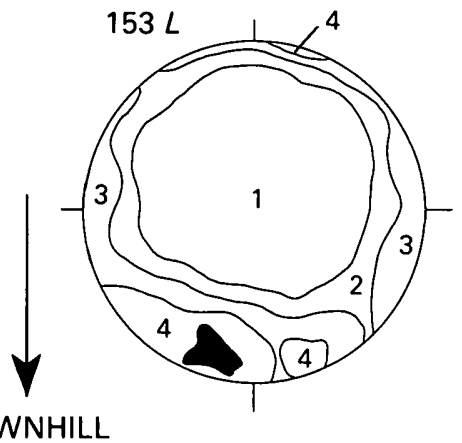

FIGURE 41.-Surface-boulder fabrics at sites 75, 140, 151, and 153. $S$ indicates short-axis fabrics and $L$ indicates long-axis fabrics. Site locations are shown on figure 2.

\section{DISCUSSION}

Table 8 summarizes the properties of the different types of boulder streams in the study area. Of these, type B streams have the greatest climatic significance and raise the most questions concerning their development. Washburn $(1980$, p. 221) suggested that most periglacial block slopes and streams have a developmental history consisting of (1) production of blocky material by weathering; (2) some frost-sorting effects; (3) movement by mass wasting; and (4) subsequent removal of some interstitial matrix.

Concerning (1) in the present study area, it has been demonstrated that in at least one location scree is being produced under the present climatic regime by the sapping of a sandstone cliff. Thus, as Hack $(1960,1965)$ has suggested, it appears that frost riving is not neces-
TABLE 7.-Percent cracked boulders at selected sites [A minimum of 100 boulders was counted at each site, and all boulders were at least $360 \mathrm{~mm}$ in intermediate diameter; site locations are shown on figure 2]

\begin{tabular}{|c|c|}
\hline Site & Percent cracked \\
\hline \multicolumn{2}{|l|}{ Type C streams } \\
\hline $\begin{array}{r}75 \\
153\end{array}$ & $\begin{array}{l}3 \\
8\end{array}$ \\
\hline \multicolumn{2}{|l|}{$\begin{array}{ll}\text { Type B1 streams } \\
\end{array}$} \\
\hline $154(1410010$ & $\begin{array}{l}27 \\
37\end{array}$ \\
\hline
\end{tabular}

sary for the production of scree, even though it may increase the rate of scree production. Therefore, the question of how the scree originates probably is less important than that of how it is transported downslope after its formation, at least in terms of paleoclimatic significance.

Regarding (2) and (3), it is of great interest to know under what circumstances frost-sorting, which involves frost-heaving, dominates as opposed to mass wasting, which includes gelifluction and frost creep, and whether the relative importance of the two types of processes may vary over time at the same location. We lack precise understanding of the circumstances under which frost-heaving dominates over gelifluction and vice versa. The dominant process, however, greatly affects the resulting sedimentary characteristics, especially the fabric, frost-sorting favoring on-end or onedge fabrics and gelifluction favoring standard slope fabrics. Thus, where the on-end or on-edge fabrics are developed, the last periglacial process to affect the deposits (or at least the upper layers of deposits) might have been frost-sorting, involving little lateral motion. Where the standard fabrics are developed, gelifluction and (or) frost creep, involving somewhat greater lateral motion, presumably were the last processes, assuming, of course, other nonperiglacial processes were not responsible.

Where deposits of on-edge Tuscarora blocks occur over Tuscarora bedrock, it can be postulated that most motion undergone by the clasts was of the vertical, frost-sorting type, so that gelifluction need never have been involved. Where such deposits occur some distance downhill from Tuscarora outcrops, however, as they commonly do, there are at least two ways to explain them: (1) Frost-sorting activity, as well as creating on-edge fabric, was also able to move blocks laterally (the deposits of the Blue Rocks block field (Potter and Moss, 1968) would seem to suggest such an origin); and (2) gelifluction (or nonperiglacial processes) moved the deposits downhill, then lateral motion ceased or greatly decreased and frost-sorting became the dominant process. A change from gelifluction to frostsorting perhaps could have resulted from a change in climatic regime. 
TABLE 8.-Comparison between types of boulder streams

\begin{tabular}{|c|c|c|c|c|}
\hline Characteristic & $\begin{array}{l}\text { Type A/ } \\
\text { type I }\end{array}$ & $\begin{array}{c}\text { Type B1/ } \\
\text { type II (frost heave) }\end{array}$ & $\begin{array}{c}\text { Type B2/ } \\
\text { type II (gelifluction) }\end{array}$ & $\begin{array}{l}\text { Type C/ } \\
\text { Type III }\end{array}$ \\
\hline Abundance........................ & Uncommon & Less common & Common & Common. \\
\hline Study sites & 137,156 & $100,141,142,154$ & $69,160,164,165$ & $75,140,151$ \\
\hline Topographic setting ........ & Upper slopes & Upper slopes & $\begin{array}{l}\text { North-facing upper } \\
\text { slopes. }\end{array}$ & $\begin{array}{c}\text { Lower slopes or } \\
\text { south-facing } \\
\text { upper slopes. }\end{array}$ \\
\hline Surface form & $\begin{array}{l}\text { Smooth with } \\
\text { straight slopes. }\end{array}$ & Irregular with pits. & $\begin{array}{l}\text { Less regular } \\
\text { than A, no pits. }\end{array}$ & $\begin{array}{l}\text { Less regular } \\
\text { than A, no pits. }\end{array}$ \\
\hline Slope angle & About $35^{\circ}$ & $10^{\circ}$ to $30^{\circ}$ & $10^{\circ}$ to $30^{\circ}$ & $10^{\circ}$ to $30^{\circ}$ \\
\hline Boulder stability & Lowest stability & Highest stability & $\begin{array}{l}\text { Intermediate } \\
\text { stability. }\end{array}$ & $\begin{array}{l}\text { Intermediate } \\
\text { stability. }\end{array}$ \\
\hline \multicolumn{5}{|l|}{ Matrix in upper } \\
\hline layer? & No & Commonly no & Commonly yes & Commonly yes. \\
\hline Boulder roundness & Lowest roundness & $\begin{array}{l}\text { Intermediate } \\
\text { roundness. }\end{array}$ & $\begin{array}{l}\text { Variable, but } \\
\text { includes greatest } \\
\text { roundness. }\end{array}$ & $\begin{array}{l}\text { Variable, but } \\
\text { includes greatest } \\
\text { roundness. }\end{array}$ \\
\hline \multicolumn{5}{|l|}{ Number of cracked } \\
\hline boulders & Few & Many & Variable & Variable. \\
\hline Boulder-fabric pattern -.... & Standard & $\begin{array}{l}\text { Many on-edge } \\
\text { clasts. }\end{array}$ & Standard & Standard. \\
\hline $\begin{array}{l}\text { Boulder-fabric } \\
\text { strength } \\
\text { Subsurface clast-fabric }\end{array}$ & Moderately strong. & Weak & Moderately strong & Moderately strong. \\
\hline strength & Unknown & Strong & Strong & Weak. \\
\hline
\end{tabular}

The strong resemblance of the subsurface colluvial fabrics of type $\mathrm{B} 1$ and type $\mathrm{B} 2$ deposits requires explanation. Perhaps, as was suggested previously, the type B2 deposits once were type B1 deposits whose surface boulder fabrics were destroyed by Holocene catastrophic floods. Alternatively, original on-edge surface fabrics on the type $\mathrm{B} 2$ deposits might have been destroyed by an episode of gelifluction that preferentially affected the lower slopes, perhaps because of greater moisture there than on the upper slopes, toward the close of the last glaciation. This sequence of events would have preserved on-edge fabrics mainly on the higher slopes. This interpretation has some support from Denny and Lyford (1963) and Delcourt (1980a, b), who have proposed an episode of colluviation at the close of the last glaciation elsewhere in the unglaciated Appalachians.

Point (4) of Washburn's suggested developmental history addresses the removal of interstitial matrix. Attributing the postglacial removal to eluviation, which is the most common interpretation, appears to be a reasonable course. Streams running beneath the upper layer of boulders could produce differential fluvial erosion beneath this layer, which in turn could result in differential settling and hence account for the pits associated with the type B1 boulder streams. It is likely, however, that some of the boulder streams, particularly the high-angle type A ones, never possessed a fine matrix between the boulders, at least not in the upper layers.

Type A boulder streams do not necessarily have any climatic significance. As scree is being actively produced today at some locations, boulder movement down the steep gradients associated with these streams can occur by gravity alone. To demonstrate that such streams are relict it would be necessary to establish that they are no longer moving, and as discussed earlier, the presence of trees on the streams does not constitute sufficient evidence for complete cessation of movement. Accurate surveys over a period of years probably would be required to prove such stability. Type $\mathrm{C}$ boulder streams likewise have no obvious climatic implications. Whether catastrophic rainfalls were more or less common during Pleistocene glacial stages than during interglacials and the Holocene is not known, although it is likely that they are more common during the warmer intervals when tropical storms reach the latitude of Virginia more often. In any case, because catastrophic floods are known to occur under the present climatic regime, a deposit that can be shown to be a flood deposit on the basis of its sedimentary properties is best considered to be Holocene in age unless dating or physical association with deposits of known age can demonstrate otherwise.

The areas of unforested boulder fields, slopes, and streams increase northward in the Appalachians. There 
is nothing in Virginia, for example, to compare with the unforested boulder fields in Pennsylvania described by Potter and Moss (1968) and Smith (1953). Even within Virginia a north-south difference can be seen. Hack (1965, fig. 19, p. 36), for example, was able to map scree deposits in the Shenandoah Valley from aerial photographs, something impossible to do in Giles County $(90$ $\mathrm{km}$ to the south) except for a few high-angle boulder streams. Part of this difference, however, may be related to the fact that the scree studied by Hack consists largely of metaquartzite, whereas the scree in Giles County consists of orthoquartzite.

Explaining this north-south difference in vegetation on boulder fields is not simple. Assuming that lithologic factors are not responsible, a difference in climate must somehow be involved, but whether present or past climatic differences are most important is unclear. Present climatic differences may affect the rate at which reforestation may occur. Perhaps a higher chemical weathering rate in the southern locales forms soil more rapidly, or perhaps a longer growing season allows trees to invade the boulder fields more rapidly. Differences in types of trees in the two areas may be another factor. Still another possibility is that the boulder deposits in the northern locales continue to be active to some extent today, although this seems unlikely.

Alternatively, Pleistocene climatic differences may be responsible. More intense frost action in the north may have produced boulder deposits that are more difficult to reforest. For example, the northern fields may have larger blocks, a thicker layer of blocks, or less matrix. Or, perhaps the northern fields were originally much larger than the southern ones. The treeless northern fields are surrounded by similar deposits that are covered with forest (Potter and Moss, 1968), suggesting that reforestation is taking place laterally from the margins. If so, then the very size of these northern fields may account for the large unforested areas they contain-there just has not been enough time to complete the reforestation process. Boulder deposits farther south, which were much smaller in their original extents, would have been quickly engulfed by the encroaching forests.

\section{SURFICIAL DEPOSITS AND SEISMICITY}

Giles County is the locus of a newly recognized seismic zone (Bollinger and Wheeler, 1982). The second largest earthquake known in the southeastern United States (MMI VIII), which occurred on May 31, 1897, apparently was centered here, and many lesser shocks have taken place since. Therefore, a major effort was made to find evidence of seismic activity in the regolith in order to obtain information on recurrence intervals. Owing to the general lack of layering of the surficial sediments, the best opportunity for finding fault movement is provided by soil profiles and the transported regolith/bedrock residuum contact. No displacement that would suggest a fault was found. Similarly, no evidence of differential uplift or subsidence, such as that reported by Russ (1982), was found, although small movements would be difficult to recognize in the rugged topography of Giles County. No features indicative of shaking, such as sand dikes (Russ, 1979), were observed in cuts through flood plains and terraces, although the coarseness of the sediments here may make such phenomena unlikely.

Boulder streams may help in the study of seismicity in this area. During the 1897 earthquake many rockfalls were observed. For example, along the railroad track tons of rock fell from overhanging cliffs; at Narrows, large rocks rolled down the mountain (Bollinger and Hopper, 1971). Seismic events of this intensity are likely to affect boulder streams, especially the unstable type A ones. Whether boulder streams differ between areas having similar bedrock geology but dissimilar seismic settings is unknown, but it seems possible that an area having more intense and frequent earthquakes, for example, might have a greater number of type $A$ streams. Differences in abundance of type A boulder streams might aid in delineation of seismic zones.

\section{CONCLUSIONS}

Hillslope deposits have rarely been studied as geomorphic entities, particularly in the unglaciated Appalachians. This paper has attempted to show that the mapping and sedimentological study of these deposits increase our understanding of landscape development. Mapping has revealed the relict nature of some transported regolith, thereby providing evidence of past changes in the topography. The presence of sandstonerich colluvium on hilltops where there are no parent sandstone outcrops upslope, for example, demonstrates the retreat of sandstone escarpments in this area. Mapping has also revealed how the surficial deposits influence hillslope form. For example, whether or not a caprock supplies resistant sandstone boulders to a mountain slope greatly affects the form of the slope by determining both the amount of retreat it undergoes and the form of the hollows incised into it.

Studies of colluvium demonstrate relative-age differences between deposits in different topographic situations, providing additional information on how the landscape evolves. Colluvium in hollows, for example, is relatively young compared to that on noses. This find- 
ing, together with the nature of the contacts between colluvium and residuum and the distribution of surface boulders, supports the concept that most downslope movement of colluvium takes place in hollows, colluvial caps on noses representing former hollow fills that reached their present positions by means of topographic inversion. That colluvial caps on lower noses are older than those on higher noses probably reflects a reduced tendency for the lateral migration of hollows on the gentler foot slopes than on the steeper higher slopes.

Sedimentological data also provide information concerning the manner in which the colluvium and boulder deposits were transported and emplaced. For example, some colluvial deposits appear to have been emplaced by laminar flow, others by turbulent flow. Some boulder streams appear to reflect the action of frost heave. Although these data by no means allow specific origins to be inferred, they do narrow the range of possibilities and also suggest that the type and (or) intensity of transport processes have varied as a function of both topographic setting and time. To the extent that the action of processes common to cold regions but not to present-day Virginia can be demonstrated (such as frost heave of boulders), evidence for former periglacial conditions can be provided.

No radiometric dates were obtained for the surficial deposits, but an order-of-magnitude estimate of age can be made by a comparison of colluvium weathering characteristics with those of Pleistocene deposits of known age elsewhere. Results of these comparisons suggest that the hollow deposits are no older than late Wisconsinan, whereas some deposits on lower noses probably are pre-Illinoian in age. Support for the latter estimate was provided by comparing the weathering characteristics of the colluvium with those of New River terrace sediments, the terraces being approximately dated by dividing their heights above the modern river level by the regional erosion rate.

Many possibilities exist for future work. Additional detailed mapping of small areas in settings of geomorphic interest would be useful. Regional mapping of boulder streams and related features thought to be relics of past climates would also be informative, as the manner in which these deposits vary as a function of latitude and altitude might indicate the degree to which they are climatically controlled. Datable organic material might be found in hollows by trenching. The best opportunities for dating surficial deposits in the Appalachians, however, exist in the terrace sediments of larger rivers, where lower terraces yield radiocarbon dates and higher terraces conceivably might be dated paleomagnetically. Most upland colluvial deposits probably can be dated only by correlation with dated terraces. Although in a few locations this correlation might be done by the physical association of colluvium and terraces, in most cases it probably will have to be done by relative-age dating techniques.

Modern hillslope processes also should be investigated in more detail. Long-term instrumental studies of creep and frost action, for example, could indicate which features are likely to be relics of former climates, and which features were formed under the modern climatic regime. In addition, much more work on the sedimentary properties of modern hillslope deposits in both temperate and periglacial climates is needed. More data are needed to allow a decision as to whether, for example, fabric strength can be used to discriminate between debris-flow and gelifluction deposits.

\section{REFERENCES CITED}

Anderson, T.W., and Stephens, M.A., 1971, Tests for randomness of directions against equatorial and bimodal alternatives: Stanford University, Department of Statistics Technical Report 5, 19 p.

Baulig, Henri, 1957, Peneplains and pediplains: Geological Society of America Bulletin, v. 68, p. 913-929.

Benedict, J. B., 1970, Downslope soil movement in a Colorado alpine region: rates, processes, and climatic significance: Arctic and Alpine Research, v. 2, p. 165-226.

1976, Frost creep and gelifluction features: a review: Quaternary Research, v. 6, p. 55-76.

Birkeland, P.W., 1973, Use of relative age-dating methods in a stratigraphic study of rock glacier deposits, Mt. Sopris, Colorado: Arctic and Alpine Research, v. 5, p. 401-416.

1974, Pedology, weathering, and geomorphological research: New York, Oxford University Press, 285 p.

Blackwelder, E. 1931, Desert plains: Journal of Geology, v. 39, p. 133-140.

Bogucki, D.J., 1970, Debris slides and related flood damage associated with the September 1, 1951, cloudburst in the Mt. Le Conte-Sugarland Mountain area, Great Smoky Mountains National Park: Knoxville, University of Tennessee, unpublished Ph.D. dissertation, 165 p.

1976, Debris slides in the Mt. Le Conte area, Great Smoky Mountains National Park, U.S.A.: Geografiska Annaler, v. 58A, p. 179-191.

Bollinger, G. A., and Hopper, M. G., 1971, The earthquake history of Virginia, 1774 to 1900: Blacksburg, Department of Geological Sciences, Virginia Polytechnic Institute and State University, $87 \mathrm{p}$.

Bollinger, G. A., And Wheeler, R. L., 1982, The Giles County, Virginia, seismogenic zone-Seismological results and geological interpretations: U.S. Geological Survey Open-File Report 82-585, $136 \mathrm{p}$.

Bones, J. G., 1973, Process and sediment size arrangement on high arctic talus, southwest Devon Island, N.W.T., Canada: Arctic and Alpine Research, v. 5, p. 29-40.

Brochu, Michel, 1978, Disposition des fragments rocheux dans les dépôt de solifluxion, dans les éboulie de gravité et dans les dépôts fluviatiles: measures dans l'est Arctique nord-Américain et comparison avec d'autres régions du globe: Biuletyn Peryglacjalny, v. 27, p. 35-51.

Bull, W. B., 1962, Relation of textural (CM) patterns of depositional environment of alluvial-fan deposits: Journal of Sedimentary Petrology, v. 32, p. 211-216. 
1964, Alluvial fans and near-surface subsidence in western Fresno County, California: U.S. Geological Survey Professional Paper 437-A, $71 \mathrm{p}$.

Burke, R. M., and Birkeland, P. W., 1979, Reevaluations of multiparameter relative dating techniques and their application to the glacial sequence along the eastern escarpment of the Sierra Nevada, California: Quaternary Research, v. 11, p. 21-51.

Cailleux André, 1947, Caractères distinctifs des coulées de blocailles liées au gel intense: Societé Geologique de France Comptes rendus, p. 323-324.

Caine, Nel, 1967, The texture of talus in Tasmania: Journal of Sedimentary Petrology, v. 37, p. 796-803.

1968, The blockfields of northeastern Tasmania: Australian National University, Department of Geography Publication G16, $127 \mathrm{p}$.

1969, A model for alpine talus slope development by slush avalanching: Journal of Geology, v. 77, p. 92-100.

Carson, M. A., 1977, Angles of repose, angles of shearing resistance and angles of talus slopes: Earth Surface Processes, v. 2, p. 363-380.

Chandler, R. J., 1973, The inclination of talus, arctic talus terraces, and other slopes composed of granular materials: Journal of Geology, v. 81, p. 1-14.

Church, Michael, Stock, R. F., and Ryder, J. M., 1979, Contemporary sedimentary environments on Baffin Island, NWT, Canada: Debris slope accumulations: Arctic and Alpine Research, v. 11, p. 371-402.

Ciolkosz, E. J., Petersen, G. W., Cunningham, R. L., and Matelski, R. P., 1979, Soils developed from colluvium in the Ridge and Valley area of Pennsylvania: Soil Science, v. 128, p. 153-162.

Clark, G. M., 1968, Sorted patterned ground: new Appalachian localities south of the glacial border: Science, v. 161, p. 355-356.

Corbato, C. E., 1965, Fabric diagrams by computer: Unpublished manuscript, Department of Geology, University of California, Los Angeles.

Dahl, Ragnar, 1966, Block fields, weathering pits and tor-like forms in the Narvik mountains, Nordland, Norway: Geografiska Annaler, v. 48A, p. 55-85.

Delcourt, P. A., 1980a, Landscape response to Quaternary climatic change in east Tennessee (abs.): Geological Society of America Abstracts with Programs, v. 12, p. 411.

1980b, Quaternary alluvial terraces of the Little Tennessee River valley, east Tennessee, in Chapman, Jefferson, ed., The 1979 archaeological and geological investigations in the Tellico Reservoir: University of Tennessee Department of Anthropology Report of Investigations 29, p. 110-121.

Denny, C. S., 1951, Pleistocene frost action near the border of the Wisconsin drift in Pennsylvania: Ohio Journal of Science, v. 51, p. $116-125$.

1956, Surficial geology and geomorphology of Potter County, Pennsylvania: U. S. Geological Survey Professional Paper 288, $72 \mathrm{p}$.

Denny, C. S., and Lyford, W. H., 1963, Surficial geology and soils of the Elmira-Williamsport region, New York and Pennsylvania: U.S. Geological Survey Professional Paper 379, 60 p.

Dietrich, R. V., 1957, Mountain Lake [Virginia]: Mineral Industries Journal, v. 4, p. 7-8.

Eckroade, W. M., 1962, Geology of the Butt Mountain area, Giles County, Virginia: Blacksburg, Virginia Polytechnic Institute and State University, M.S. thesis, 62 p.

Embleton, Clifford, and King, C. A. M., 1975, Periglacial geomorphology: New York, John Wiley \& Sons, 203 p.

Fiedler, F. J., 1967, Surficial geology of the Mountain Lake area, Giles County, Virginia: Blacksburg, Virginia Polytechnic Institute and State University, M.S. thesis, 108 p.
Folk, R. L., and Ward, W. C., 1957, Brazos River bar: a study in the significance of grain size parameters: Journal of Sedimentary Petrology, v. 27, p. 3-26.

Gardner, J. S., 1971, Morphology and sediment characteristics of mountain debris slopes in Lake Louise district (Canadian Rockies): Zeitschrift fuer Geomorphologie, v. 15, p. 390-403.

Godfrey, A. E., 1975, Chemical and physical erosion in the South Mountain anticlinorium, Maryland: Maryland Geological Survey, Information Circular 19, $35 \mathrm{p}$.

Gryta, J. J., and Bartholomew, M. J., 1983, Debris-avalanche type features in Wautauga County, North Carolina, in Lewis, S. E. ed., Geologic investigations in the Blue Ridge of northwestern North Carolina: Carolina Geological Society Field Trip Guidebook, Oct. 21-23, 1983, 22 p.

Hack, J. T., 1960, Origin of talus and scree in northern Virginia [abs.] Geological Society of America Bulletin, v. 71, p. 1877-1878.

1965 , Geomorphology of the Shenandoah Valley, Virginia and West Virginia, and origin of the residual ore deposits: U.S. Geological Survey Professional Paper 484, 83 p.

1973, Stream-profile analysis and stream-gradient index: U.S. Geological Survey Journal of Research, v. 1, p. 421-429.

1979, Rock control and tectonism-Their importance in shaping the Appalachian Highlands: U.S. Geological Survey Professional Paper 1126-B, $17 \mathrm{p}$.

Hack, J. T., and Goodlett, J. C., 1960, Geomorphology and forest ecology of a mountain region in the central Appalachians: U.S. Geological Survey Professional Paper 347, 66 p.

Hadley, J. B., and Goldsmith, Richard, 1963, Geology of the eastern Great Smoky Mountains, North Carolina and Tennessee: U.S. Geological Survey Professional Paper 349-B, 118 p.

Haselton, G. M., 1973, Possible relict glacial features in the Black Balsam Knob and Richard Balsam area, North Carolina: Southeastern Geology, v. 15, p. 119-125.

Hedges, James, 1975, Multiple cycles of cryoplanation on Sugarloaf Mountain, Maryland: Biuletyn Peryglacjalny, v. 24, p. 233-244.

Houser, Brenda, 1980, Erosional history of the New River, southern Appalachians, Virginia: Blacksburg, Virginia Polytechnic Institute and State University, unpublished Ph.D. dissertation, $309 \mathrm{p}$.

Hutchinson, G. E., and Pickford, G. E., 1932, Limnological observations on Mountain Lake, Virginia: Internationale Revue Gesamten Hydrobiologie, v. 27, p. 252-264.,

Kamb, W. B., 1959, Ice petrofabric observations from Blue Glacier, Washington, in relation to theory and experiment: Journal of Geophysical Research, v. 64, p. 1891-1904.

King, P. B., 1964, Geology of the central Great Smoky Mountains, Tennessee: U.S. Geological Survey Professional Paper 349-C, $148 \mathrm{p}$.

Kirby, R. P., 1967, The fabric of head deposits in south Devon: Redruth, England, Proceedings of the Ussher Society, v. 1, p. 288-290.

Klatka, Tadeusz, 1961, Indices de structure et de texture des champs de pierres des Lysógory: Bulletin de la Societé des Sciences et des Letteres de Lodz, v. 12, no. 10, p. 1-21.

1962, Geneza i wiek globorzy Lysogorskich: Acta Geographica Lodziensia, v. 12, 129 p.

Kochel, R. C., and Johnson, R. A., 1984, Geomophology and sedimentology of humid-temperate alluvial fans, central Virginia, in Koster, E. H., and Steel, R. J., eds., Sedimentology of gravels and conglomerates: Canadian Society of Petroleum Geologists, Memoir 10, p. 109-122.

Krumbein, W. C., 1941, Measurement and geological significance of shape and roundness of sedimentary particles: Journal of Sedimentary Petrology, v. 11, p. 64-72.

Landim, P. M. B., and Frakes, L. A., 1968, Distinction between tills 
and other diamictons based on textural characteristics: Journal of Sedimentary Petrology, v. 38, p. 1213-1223.

Lindsay, J. F., 1968, The development of clast fabric in mudflows: Journal of Sedimentary Petrology, v. 38, p. 1242-1253.

Lundqvist, Gösta, 1949, The orientation of the block material in certain species of flow earth: Geografiska Annaler, v. 31, p. 335-347.

McSaveney, E. R. 1972, The surficial fabric of rockfall talus, in Morisawa, Marie, ed., Quantitative geomorphology: some aspects and applications: Second Annual Geomorphology Symposia Series (Binghamton, October 15-16, 1971): Proceedings, Binghamton, State University of New York, Publications in Geomorphology, p. 181-197.

Mark, D. M., 1973, Analysis of axial orientation data, including till fabrics: Geological Society of America Bulletin, v. 84, p. 1369-1374.

Marland, F. C., 1967, The history of Mountain Lake, Giles County, Virginia: an interpretation based on paleolimnology: Blacksburg, Virginia Polytechnic Institute and State University, unpublished Ph.D. dissertation, 129 p.

Michalek, D. D., 1968, Fanlike features and related periglacial phenomena of the southern Blue Ridge: Chapel Hill, University of North Carolina, unpublished Ph.D. dissertation, $198 \mathrm{p}$.

Mills, H. H., 1977, Slope deposits on the north side of Little Pinnacle Mountain, South Carolina: South Carolina Division of Geology, State Development Board, Geologic Notes, v. 21, p. 150-163.

1978, Some characteristics of glacial sediments on Mount Rainier, Washington: Journal of Sedimentary Petrology, v. 48, p. 1345-1356.

1979, Downstream rounding of pebbles-a quantitative review: Journal of Sedimentary Petrology, v. 49, p. 295-302.

1981, Boulder deposits and the retreat of mountain slopes, or "gully gravure" revisited: Journal of Geology, v. 89, p. 649-660. 1983 , Clast-fabric strength in hillslope colluvium as a function of slope angle: Geografiska Annaler, v. 65A, p. 255-262.

1984, Clast orientation in Mount St. Helens debris-flow deposits, North Fork Toutle River, Washington: Journal of Sedimentary Petrology, v. 54, p. 626-634.

Mills, H. H., and Wagner, J. R., 1985, Long-term change in regime of the New River indicated by vertical variation in extent and weathering intensity of alluvium: Journal of Geology, v. 93, p. 131-142.

Mottershead, D. N., 1976, Quantitative aspects of periglacial slope deposits in southwest England: Biuletyn Peryglacjalny, v. 25, p. 35-57.

Munsell Color, 1975, Munsell soil color charts: MacBeth Division, Kollmorgen Corporation, Baltimore, Maryland.

Nelson, Fritz, 1985, A preliminary investigation of solifluction macrofabrics: Catena, v. 12, p. 23-33.

Ovenshine, A. T., 1961, Geology of the Spruce Run Mountain area, Giles County, Virginia: Blacksburg, Virginia Polytechnic Institute and State University, M.S. thesis, 71 p.

Parker, B. C., Wolfe, H. E., and Howard, R. V., 1975, On the origin and history of Mountain Lake, Virginia: Southeastern Geology, v. 16, p. 213-226.

Peltier, L. C., 1949, Pleistocene terraces of the Susquehanna River, Pennsylvania: Pennsylvania Geological Survey, 4th series, Bulletin G23, $147 \mathrm{p}$

Pierce, K. L., 1965, Geomorphic significance of a Cretaceous deposit in the Great Valley of southern Pennsylvania: U.S. Geological Survey Professional Paper 525-C, p. C152-C156.

1966, Bedrock and surficial geology of the McConnellsburg quadrangle: Pennsylvania Topographical and Geological Survey Atlas 109a, 111 p.

Pierson, T. C., 1980, Erosion and deposition by debris flows at Mt.
Thomas, North Canterbury, New Zealand: Earth Surface Processes, v. 5, p. 227-247.

Platt, R. B., and Shoup, C. S., 1950, The use of a thermister in a study of summer temperature conditions of Mountain Lake, Virginia: Ecology v. 31, p. 484-488.

Potter, Noel, Jr., and Moss, J. H., 1968, Origin of the Blue Rocks block field and adjacent deposits, Berks County, Pennsylvania: Geological Society of America Bulletin, v. 79, p. 255-262.

Raymond, L. A., 1977, Glacial, periglacial, and pseudo-glacial features in the Grandfather Mountain area, North Carolina: Southeastern Geology, v. 18, p. 213-229.

Rogers, W. B., 1884, Report of the geological reconnoissance of the State of Virginia, made under the appointment of the Board of Public Works, 1835, in a reprint of annual reports and other papers on the geology of the Virginias: New York, D. Appleton Co., p. 109-110.

Russ, D. P., 1979, Late Holocene faulting and earthquake recurrence in the Reelfoot Lake area, northwestern Tennessee: Geological Society of America Bulletin, v. 90, p. 1013-1018.

1982, Style and significance of surface deformation in the vicinity of New Madrid, Missouri: U.S. Geological Survey Professional Paper 1236-H, p. 95-114.

Scheidegger, A. E., 1965, On the statistics of the orientation of bedding planes, grain axes, and similar sedimentological data: U.S. Geological Survey Professional Paper 525-C, p. C164-C167.

Scott, K. M., 1971, Origin and sedimentology of 1969 debris flows near Glendora, California: U.S. Geological Survey Professional Paper 750-C, p. C242-247.

Scott, R. C., Jr., 1972, The geomorphic significance of debris avalanching in the Appalachian Blue Ridge Mountains: Athens, University of Georgia, unpublished Ph.D. dissertation, $185 \mathrm{p}$.

Shanholtz, W. H., 1955, Ordovician limestones in the vicinity of Hoges Store, Giles County, Virginia: Blacksburg, Virginia Polytechnic Institute and State University, M.S. thesis, 24 p.

Sharp, H. S., 1933, The origin of Mountain Lake, Virginia: Journal of Geology, v. 41, p. 636-641.

Sharp, R.P., 1969, Semiquantitative differentiation of glacial moraines near Convict Lake, Sierra Nevada, California: Journal of Geology, v. 77, p. 68-91.

Smith, H. T. U., 1953, The Hickory Run boulder field, Carbon County, Pennsylvania: American Journal of Science, v. 251, p. 625-642.

Statham, Ian, 1976, Debris flows on vegetated screes in the Black Mountains, Carmarthenshire: Earth Surface Processes, v. 1, p. 173-181.

Swartz, F. M. 1929, The Helderberg Group from central Pennsylvania to southwestern Virginia: Pennsylvania Academy of Science Proceedings, v. 3, p. 75-88.

Vorndrang, Gerhard, 1972, Kryopedologische Untersuchungen mit Hilfe von Bodentemperaturmessungen (an einem zonalen Struckturbodenvorkommen in det Silvrettagruppe): Munchener Geographische Abhandlungen 6, 70 p.

Wahrhaftig, Clyde, and Cox, Allan, 1959, Rock glaciers in the Alaska Range: Geological Society of America Bulletin, v. 70, p. 383-436.

Washburn, A. L., 1973, Periglacial processes and environments: New York, St. Martins Press, 320 p.

1980, Geocryology: A survey of periglacial processes and environments: New York, John Wiley \& Sons, 406 p.

Watson, Edward, 1969, The slope deposits in the Nant Iago valley near Cader Idris, Wales: Biuletyn Perglacjalny, v. 18, p. 95-113.

Watts, W. A., 1979, Late Quaternary vegetation of central Appalachian and the New Jersey Coastal Plain: Ecological Monographs, v. 49 , no. 4 , p. $427-69$. 
Wentworth, C. K., 1922, A scale of grade and class terms for clastic sediments: Journal of Geology, v. 30, p. 377-392.

Williams, G. P., and Guy, H. P., 1973, Erosional and depositional aspects of Hurricane Camille in Virginia, 1969: U.S. Geological Survey Professional Paper 804, 80 p.
Young, Anthony, 1974, The rate of slope retreat, in Brown, E. H., and others, eds., Progress in geomorphology: London, Institute of British Geographers, Special Publication 7, p. 65-78.

Zingg, T., 1935, Beitrag zur Schotteranalyse: Schweizerische, Mineralogische, und Petrographische Mitteilungen, v. 15, p. 38-140. 